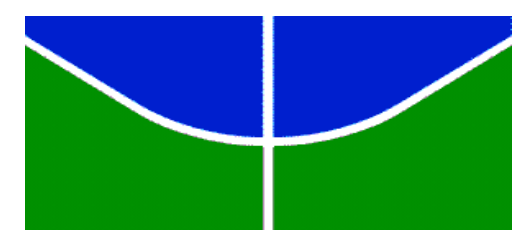

Universidade de Brasília

Centro de Excelência em Turismo

Mestrado Profissional em Turismo

\title{
A VALORIZAÇÃO DO PATRIMÔNIO DE 'PEDRA-E-CAL' EM BRASÍLIA E O POSSÍVEL REFLEXO NO INCREMENTO DO TURISMO
}

Simone Spíndola Martins 


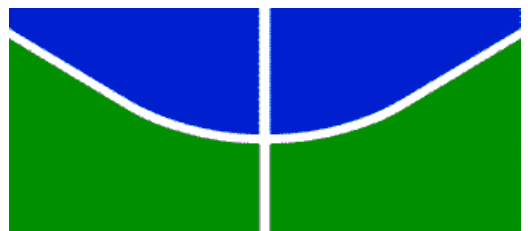

Universidade de Brasília

Centro de Excelência em Turismo

Mestrado Profissional em Turismo

\section{A VALORIZAÇÃO DO PATRIMÔNIO DE 'PEDRA-E-CAL' EM BRASÍLIA E O POSSÍVEL REFLEXO NO INCREMENTO DO TURISMO}

Simone Spíndola Martins

Dissertação apresentada ao Programa de PósGraduação em Turismo, Mestrado Profissional em Turismo, da Universidade de Brasília Área de Concentração: - Área de Concentração: Cultura e Desenvolvimento Regional; Linha de Pesquisa: Desenvolvimento, Políticas Públicas e Gestão do Turismo -, como requisito parcial para obtenção do título de Mestre em Turismo.

Orientadora: Prof $^{\mathrm{a}}$. Dr ${ }^{\mathrm{a}}$. Eloísa Pereira Barroso

\section{Brasília-DF}


Ficha catalográfica elaborada automaticamente, com os dados fornecidos pelo(a) autor(a) BRASÍLIA E O POSSÍVEL REFLEXO NO INCREMENTO DO TURISMO / Simone Spíndola Martins; orientador Eloísa Pereira Barroso. -- Brasília, 2015. $138 \mathrm{p}$.

Dissertação (Mestrado - Mestrado Profissional em Turismo) -- Universidade de Brasília, 2015.

1. Patrimônio Cultural. 2. PPCUB. 3. Turismo. 4. Identidades. 5. Distrito Federal. I. Barroso, Eloísa Pereira, orient. II. Título. 


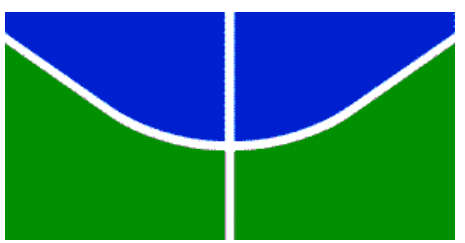

Universidade de Brasília

Centro de Excelência em Turismo

Mestrado Profissional em Turismo

Dissertação de autoria de Simone Spindola Martins, intitulada A VALORIZAÇÃO DO PATRIMÔNIO DE 'PEDRA-E-CAL' EM BRASÍLIA E O POSSÍVEL REFLEXO NO INCREMENTO DO TURISMO, submetida ao Centro de Excelência em Turismo da Universidade de Brasília - Área de Concentração: Cultura e Desenvolvimento Regional; Linha de Pesquisa: Desenvolvimento, Políticas Públicas e Gestão do Turismo -, como parte dos requisitos necessários para obtenção do grau de Mestre em Turismo, defendida e aprovada pela banca examinadora abaixo assinada:

Prof ${ }^{\mathrm{a}}$. Dra ${ }^{\mathrm{a}}$. Eloísa Pereira Barroso (Presidente)

Universidade de Brasília - CET/ UnB

Prof. Dr. Luiz Carlos Spiller Pena (Membro interno)

Universidade de Brasília - UnB

Prof. Dr. João Paulo Faria Tasso (Membro externo)

Universidade de Brasília - CET/ UnB

Prof ${ }^{a}$. Dra. Marutschka Martini Moesch (Suplente)

Universidade de Brasília - CET/ UnB

Brasília-DF, 2015. 


\section{AGRADECIMENTOS}

Agradeço à minha mãe por sempre me apoiar incondicionalmente.

À minha orientadora pela paciência e compreensão.

Ao amigo Febo Câmara por possibilitar minha dedicação necessária para a finalização desta pesquisa.

Aos colegas maravilhosos que encontrei durante a realização desse curso que sempre se mostraram dispostos a apoiarem uns aos outros.

E a todos que participaram direta ou indiretamente para a realização desse trabalho. 


\section{RESUMO}

A presente dissertação teve como objetivo investigar como o Patrimônio Cultural do Distrito Federal é gerido, no sentido de promover sua preservação e valorização enquanto bem público e vetor de identidades culturais. Além da condição de Patrimônio Cultural da Humanidade, Brasília, representada pelo seu conjunto urbanístico, detém os títulos de Patrimônio Cultural do Brasil e Patrimônio Cultural do Distrito Federal. Além disso, na cidade encontramos inventariados 61 bens tombados, até dezembro de 2014. Por meio de análise documental, buscamos explorar como é a atuação do poder público na implementação de medidas para a valorização do patrimônio cultural edificado e sua contribuição para o incremento do turismo local. Para isso, foi feita uma pesquisa em documentos oficiais, dentre eles, a legislação que dispõe sobre o patrimônio cultural do Distrito Federal, relatórios do Comitê do Patrimônio Mundial (ligado à Unesco), como também os planos governamentais para a gestão da área tombada de Brasília, com destaque para o Plano de Preservação do Conjunto Urbanístico de Brasília, o PPCUB. Enquanto metodologia, foi utilizada a da pesquisa qualitativa visto que esta perspectiva é a que melhor nos oferece um caminho possível de realização da investigação de um fenômeno social, por esse motivo permeado de subjetividades, tal como o objeto deste trabalho; como também é a que melhor responde aos objetivos desta pesquisa.

Palavras-chave: Patrimônio Cultural. PPCUB. Turismo. Identidades. Distrito Federal. 


\begin{abstract}
This work aimed to investigate how the Cultural Heritage of Distrito Federal is managed, in order to promote their preservation and valorization as a public good and vector of cultural identities. In addition to the Cultural Heritage of Humanity condition, Brasilia, represented by its urban set, holds the Cultural Heritage Titles in Brazil and Cultural Heritage of Distrito Federal. Moreover in the city we found 61 inventoried buildings, until December 2014. By means of document analysis, we seek to explore what is the role of the government in implementing measures to the appreciation of the built cultural heritage and its contribution to the increase in local tourism. For this, a survey was conducted in official documents, among them the law which deals with the cultural heritage of the Distrito Federal, reports of the World Heritage Committee (attached to Unesco) as well as the government plans for managing the tombed area of Brasília, highlighting the Urban Assembly Preservation Plan of Brasilia, the PPCUB. As methodology, we have used qualitative research as this perspective is the one that best gives us a possible way of carrying out the investigation of a social phenomenon permeated with subjectivity as the object of this work; it is also the one that best responds to the objectives of this research.
\end{abstract}

Keywords: Cultural heritage. PPCUB. Tourism. Identities. Distrito Federal. 


\section{LISTA DE TABELAS}

Tabela 1 - Bens Tombados pelo Iphan no Distrito Federal...................................................45

Tabela 2 - Patrimônio Cultural do Distrito Federal.....................................................................53

Tabela 3 - Patrimônio Cultural do Distrito Federal...................................................................59 


\section{LISTA DE GRÁFICOS}

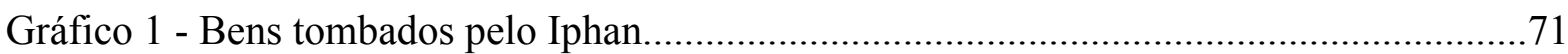

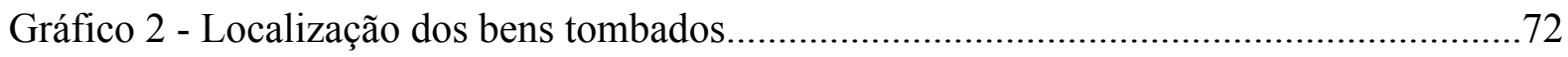




\section{LISTA DE FIGURAS}

Figura 1 - Panteão da Pátria e da Liberdade Tancredo Neves................................................44

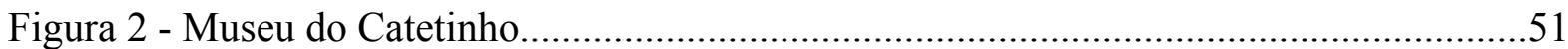

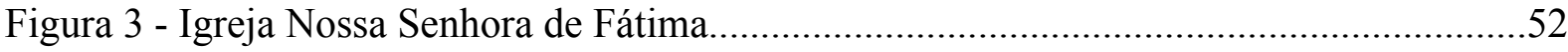

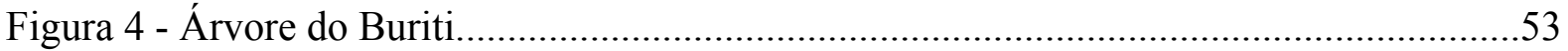

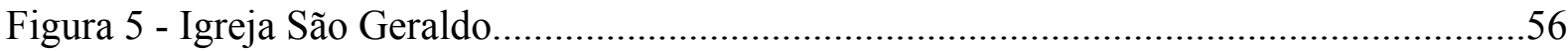

Figura 6 - Caixa d'água da Ceilândia....................................................................................58

Figura 7 - Convite para o "Ato em defesa do Patrimônio Cultural do DF”.............................61

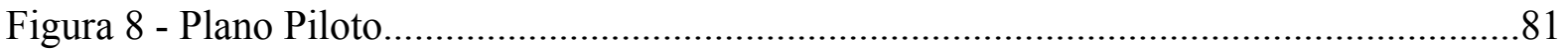




\section{LISTA DE MAPAS}

Mapa 1 - Área de abrangência do Plano de Preservação do Conjunto Urbanístico de

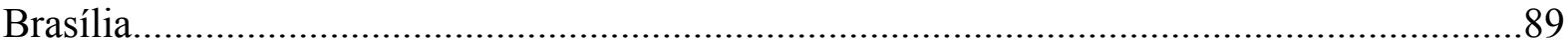




\section{LISTA DE SIGLAS}

AGEFIS - Agência de Fiscalização o Distrito Federal

CLDF - Câmara Legislativa do Distrito Federal

CNRC - Centro Nacional de Referência Cultural

CODEPLAN - Companhia de Planejamento do Distrito Federal

CONPLAN - Conselho de Planejamento Territorial do Distrito Federal

DEPHA - Departamento de Patrimônio Histórico e Artístico do Distrito Federal

EMBRAFILME - Empresa Brasileira de Filmes Sociedade Anônima

FUNARTE - Fundação Nacional de Artes

FUNDURB - Fundo de Desenvolvimento Urbano do Distrito Federal

GDF - Governo do Distrito Federal

GT BRASÍLIA - Grupo de Trabalho para Preservação do Patrimônio Cultural do Distrito Federal

HJKO - Hospital Juscelino Kubitschek de Oliveira

ICOMOS - Conselho Internacional de Monumentos e Sítios

IHGB - Instituto Histórico e Geográfico Brasileiro

IPHAC - Instituto do Patrimônio Artístico e Cultural

IPHAN - Instituto do Patrimônio Histórico e Artístico Nacional

LODF - Lei Orgânica do Distrito Federal

LUOS - Lei de Uso do Solo

NOVACAP - Companhia Urbanizadora da Nova Capital do Brasil

PDOT - Plano Diretor de Ordenamento Territorial do Distrito Federal

PLC - Projeto de Lei Complementar

PNC - Plano Nacional de Cultura

PPCUB - Plano de Preservação do Conjunto Urbanístico de Brasília 
SEC - Secretaria de Educação e Cultura do Distrito Federal

SECULT - Secretaria de Estado de Cultura do Distrito Federal

SEDEST - Secretaria de Estado de Desenvolvimento Social e Transferência de Renda do

Distrito Federal

SEDHAB - Secretaria de Habitação, Regularização e Desenvolvimento Urbano

SEGETH - Secretaria de Estado de Gestão do Território e Habitação do Distrito Federal

SETUR - Secretaria de Estado de Turismo do Distrito Federal

SNIIC - Sistema Nacional de Informações e Indicadores Culturais

SPHAN - Serviço do Patrimônio Histórico e Artístico Nacional

SUPHAC - Subsecretaria do Patrimônio Histórico, Artístico e Cultural

TCB - Sociedade de Transportes Coletivos de Brasília LTDA

TCDF - Tribunal de Contas do Distrito Federal

UNESCO - Organização das Nações Unidas para a Educação, a Ciência e a Cultura

VLT - Veículo Leve sobre Trilhos

ZUCT - Zona Urbana do Conjutno Tombado 


\section{SUMÁRIO}

INTRODUÇÃO ..............................................................................................................16

CAPÍTULO 1 - CONTEXTUALIZAÇÃO DO PATRIMÔNIO PEDRA E CAL .............21

1.1 Colecionismo, monumentos e monumentos históricos: o advento do patrimônio

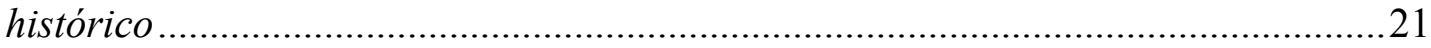

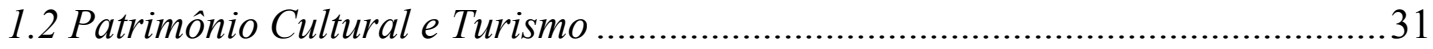

1.2.1 Concepções sobre o turismo e sua relação com o patrimônio cultural ..............31

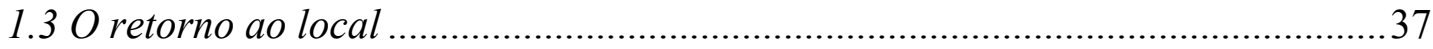

1.4 Os órgãos gestores do patrimônio cultural brasileiro .........................................38

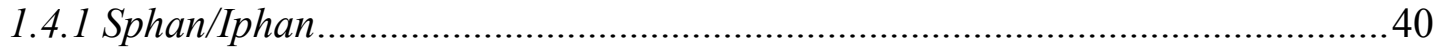

CAPÍTULO 2 - O PATRIMÔNIO CULTURAL DE BRASÍLIA: SUA

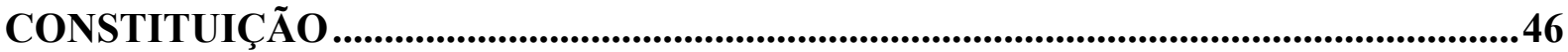

2.1 Patrimônio Cultural do Distrito Federal - GDF ...................................................49

2.1.1 A Secretaria de Cultura do Distrito Federal - Um breve histórico ..................49

2.2 A dinâmica do tombamento no $D F$................................................................51

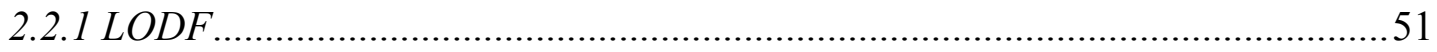

2.2.2 Decreto $n^{\circ} 10.829$, de 14 de outubro de 1987................................................52

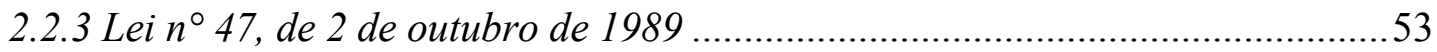

2.3 A formação do Patrimônio Cultural do Distrito Federal .....................................53

2.4 A gestão e a preservação do patrimônio cultural de Brasília ................................63

2.5 Brasília como "Patrimônio Cultural da Humanidade" ...........................................66

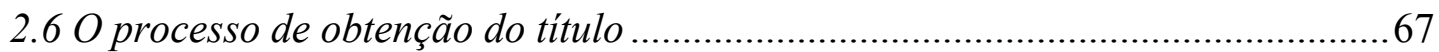

2.7 O tombamento e o turismo: uma relação possível? .............................................69

CAPÍTULO 3 - A GESTÃo DO PATRIMÔNIO CULTURAL DO DISTRITO FEDERAL: UMA ANÁLISE DA ATUAÇÃO DO PODER PÚBLICO ............................72

3.1 A gestão do patrimônio cultural no Distrito Federal ............................................. 74

3.2 As ameaças ao título e a contribuição popular: as recomendações da Unesco e o

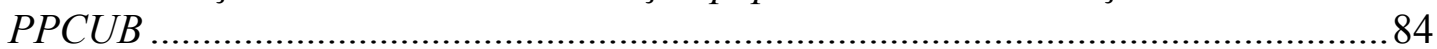

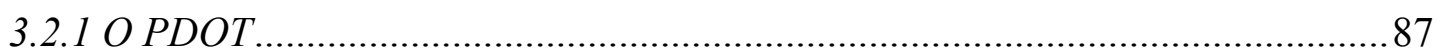

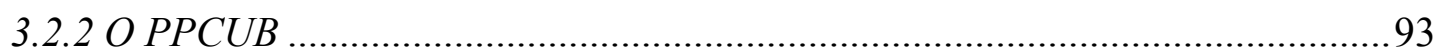

3.3 PPCUB, patrimônio cultural e turismo ............................................................. 95

3.4 O Conjunto Urbanístico de Brasília - uma tentativa pelo PPCUB ..................... 98

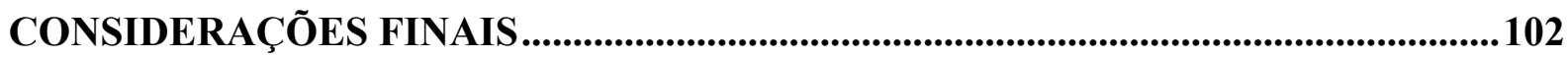

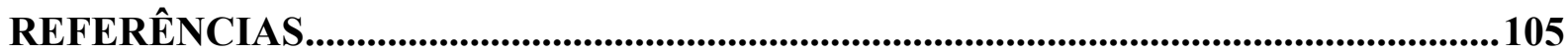




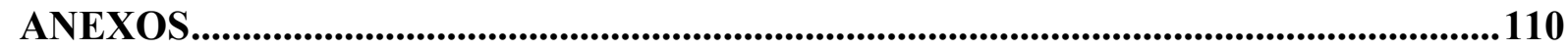

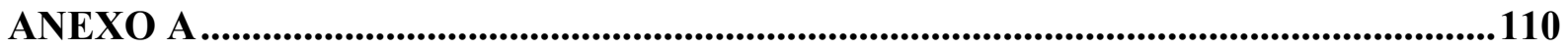

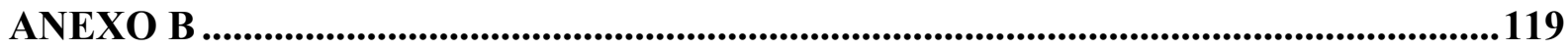

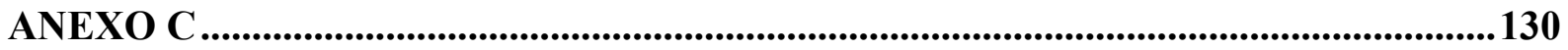

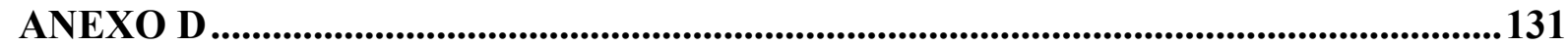




\section{INTRODUÇÃO}

Meu interesse pelo tema do Patrimônio Cultural de Brasília é fruto de algumas inquietações experimentadas como servidora pública e moradora do Distrito Federal. As inquietações surgem da dupla visão que essas duas identidades fazem com que eu me relacione com o patrimônio local. A monumentalidade de Brasília não foi apenas recurso para cartões postais. Ela impactou (e impacta) também naqueles que escolheram a capital para morar e fixar suas famílias. Os monumentos espalhados pela cidade sempre fizeram parte do nosso "quintal". Com o passar do tempo, me tornei servidora pública e a prática cotidiana me levou a procurar entender como ocorre a gestão desse patrimônio. Não nos atemos apenas ao Conjunto Urbanístico de Brasília, mas a outras edificações tombadas no Distrito Federal.

Ao longo desta pesquisa, percebe-se que o Patrimônio ultrapassa seu caráter monumental. Ele é um elemento de identificação social. A constituição do Patrimônio Cultural de uma localidade requer, antes de tudo, seu reconhecimento pela comunidade que o cerca. Tal reconhecimento se dá pela importância, pelo significado que os bens culturais têm para a sua comunidade. Seu significado está inteiramente relacionado à história, memória e identidade dessa comunidade. Nesse sentido, o Patrimônio opera com um elemento diferenciador entre o morador local, onde esse Patrimônio se encontra, e o visitante turista, pois é expressão de alteridades culturalmente localizáveis no tempo e no espaço.

O tombamento dos patrimônios, a exemplo das edificações ou monumentos, é importante para que eles adquiram um nível de universalidade, ganhando, desse modo, legitimidade enquanto elementos representativos de fatos históricos, expressões culturais ou artísticas de determinadas localidades. O reconhecimento dos bens culturais, pela sua comunidade, como também pelos órgãos públicos responsáveis pela sua manutenção e preservação, significa e ressignifica a localidade/cidade detentora desses bens.

As cidades que possuem o patrimônio cultural chancelado oficialmente possibilitam sua condição de destinos turísticos. As viagens motivadas pelo conhecimento do patrimônio local estão na mesma corrente proporcionada pela condição pós-moderna. A ideia de unidade que se esperava que mundo tomaria deu lugar ao localismo, onde as expressões culturais regionais, por serem únicas, adquirirem peso na escolha dos turistas.

O patrimônio, vivenciado a partir do turismo, decorre de uma prática social. E essa experiência possui sua riqueza pelo fato de ser única, pois sua fruição se passa em uma 
dimensão individual. Porém, o contexto em que se apresenta o patrimônio, inclusive como um recurso turístico, pode levar a uma contestação da legitimação dada pelos órgãos governamentais, pois a difusão da ideia de universalidade do patrimônio como bem coletivo, por vezes, demonstra a redução da totalidade brasileira, ao se desprezar as manifestações culturais estranhas à apreciação da elite intelectual. Mas veremos mais adiante que essa realidade está sendo modificada.

Diante da dimensão do tema, o Patrimônio de Pedra e Cal, realizamos um recorte para melhor operacionalizar a pesquisa e oferecer uma análise mais profunda sobre o objeto pesquisado. Desse modo, o nosso objetivo, neste trabalho, foi o de investigar a constituição do patrimônio edificado do Distrito Federal e a atuação do poder público na valorização do patrimônio cultural enquanto elemento sensibilizador da sociedade e como fator possível e viável de promoção e incentivo ao turismo, no contexto do desenvolvimento social, econômico e cultural.

Cabe ressaltar que a importância de analisar a gestão do patrimônio cultural no âmbito distrital se justifica pelo fato de o mecanismo do tombamento não se deter apenas ao campo das ações públicas, mas, principalmente, por ser um instrumento de representação cultural e social.

Por muito tempo no Brasil o patrimônio cultural foi concebido como o conjunto formado por obras de arte e pela arquitetura, com a valorização somente de monumentos e edificações de "valor excepcional", demonstrando manifestamente a influência de um segmento elitizado na constituição desse patrimônio. As manifestações populares só viriam a ter reconhecimento décadas mais tarde. E em Brasília não foi diferente. A capital que foi erguida como símbolo do país moderno e desenvolvimentista e, portanto, deveria abrigar a cultura síntese do Brasil, tornando a "cultura candanga" representativa da fusão das expressões culturais brasileiras, não conseguiu cumprir sua missão inicial. Como afirma Woodward (2012), todas as práticas de significação que produzem significados envolvem relações de poder, incluindo nelas o poder de definir quem é incluído e quem é excluído. Assim, a identidade vinculada ao patrimônio oficialmente constituído possui um aspecto relacional, depende da marcação da diferença sustentada pela exclusão.

Dessa forma, o que guiou o interesse originário dessa pesquisa foi a relação de representatividade que o patrimônio oficializado tem com a diversidade cultural do Distrito Federal. A escolha do Conjunto Urbanístico do Plano Piloto, como Patrimônio Cultural da Humanidade se deu por servir de exemplo como se desenvolve a gestão do patrimônio 
cultural da capital, tendo em vista que o título passou por avaliações do organismo internacional (Unesco) que o concedeu. Em contrapartida, o Governo do Distrito Federal criou mecanismos para garantir a permanência da inscrição da cidade na lista do patrimônio mundial, através da valorização do patrimônio cultural local. Dentre esses mecanismos está o PPCUB, que tem a intenção de resguardar o título e criar diretrizes para orientar o crescimento da cidade na área tombada.

Assim optamos pela análise documental, essencialmente de documentos públicos. Esse tipo de análise permite certa distância do pesquisador, como ratifica Cellard (2008). De certo modo, é eliminada a influência do sujeito, em decorrência da ausência de contato direto com outras pessoas. Se a metodologia de uma pesquisa está intimamente ligada às características do objeto a ser investigado, no caso do presente estudo, para a análise da atuação dos órgãos de gestão do patrimônio cultural, utilizamos documentos oficiais (legislação, listas oficiais etc) para conhecer a história e a dinâmica do processo de gestão do patrimônio cultural no Distrito Federal.

A pesquisa documental foi realizada junto à Secretaria de Cultura do Distrito Federal SeCult, à Secretaria de Gestão do Território e Habitação do Distrito Federal - Segeth e à Superintendência do Instituto do Patrimônio, Histórico e Artístico Nacional - Iphan. Foram feitas consultas a documentos governamentais pertinentes ao tema para saber como se dá a gestão desse patrimônio e sua relação com a atividade turística desenvolvida localmente. Foi realizada a pesquisa documental junto às instituições responsáveis pela gestão e preservação do patrimônio cultural do Distrito Federal. Para este trabalho, para saber como se dá a gestão desse patrimônio e sua relação com a atividade turística desenvolvida localmente, buscamos documentos governamentais junto à Secretaria de Cultura do Distrito Federal - SeCult, Secretaria de Gestão do Território e Habitação do Distrito Federal - Segeth, Secretaria de Turismo do Distrito Federal e Superintendência do Instituto do Patrimônio, Histórico e Artístico Nacional - IPHAN (sede Brasília).

Essencialmente, foi analisada a legislação pertinente ao tema, como também foram utilizadas, em complementação, matérias de jornais para se obter dados primários sobre a constituição do patrimônio cultural edificado da região. Tais documentos foram tratados enquanto representações do real, por expressar valores, ideias, práticas, através dos quais conseguimos acessar o imaginário coletivo sobre o patrimônio do Distrito Federal, ao longo do processo de sua constituição, manutenção e valorização pelo poder público e sociedade civil. Portanto, na tentativa de tornar inteligível os significados do real implícitos na 
documentação, lançamos mão de sua leitura indo do texto (documento) ao contexto pesquisado.

Porém, como afirma Cellard (2008), o documento é um instrumento que o pesquisador não domina, pois não é possível exigir complementações. Ele pode se apresentar incompleto, parcial ou impreciso, mas não há como alterá-lo. Assim, tentamos complementar a análise da constituição e gestão do patrimônio cultural do Distrito Federal por meio de consulta a livros, teses, dissertações, artigos e revistas. Foi empreendida uma constante consulta a esses documentos como forma de acesso a essa memória documentada. Dessa forma, optamos pelo procedimento metodológico da pesquisa documental, onde tentamos pelo processo de análise de conteúdo, já com objeto de pesquisa em mente, analisar os documentos oficiais a partir de seu contexto.

Dessa maneira este estudo está dividido em três capítulos, nos quais se tentou estabelecer uma leitura que buscasse a relação entre a gestão desse patrimônio e o significado dessa gestão na promoção turística da cidade.

No capítulo 1, traçamos um breve histórico da formação do patrimônio cultural brasileiro, seus significados para os que o elegeram enquanto bem cultural, e sua importância na constituição e reconhecimento de identidades sociais. Abordamos a criação dos órgãos governamentais responsáveis pela gestão do patrimônio brasileiro que, na época, privilegiavam a preservação do patrimônio edificado, denominado de "pedra e cal". A contrapelo desta perspectiva, a medida que as listas de tombo cresciam com o passar dos anos, determinados grupos sociais, muitos deles formados pela intelectualidade brasileira, começaram a questionar se esse patrimônio "oficial" realmente era representativo da diversidade cultural brasileira. Além disso, discutimos os conceitos de monumento e monumento histórico, patrimonialização, identidade e algumas concepções sobre evolução do turismo, e a maneira como este se apropriou do patrimônio enquanto elemento turístico.

No segundo capítulo, procuramos apresentar como se deu a constituição do patrimônio cultural do Distrito Federal e os órgãos responsáveis por sua gestão e preservação. Buscamos demonstrar como se dá o processo de tombamento e procuramos reunir a legislação pertinente ao tema, no que diz respeito principalmente à valorização desse patrimônio. Além disso, apresentamos os bens tombados na Capital pelas duas esferas governamentais (distrital e federal) e a representatividade que eles carregam para os órgãos oficiais e para a população local. Uma atenção especial foi destinada ao Conjunto Cultural de Brasília, pois a análise das ações do poder público para preservá-lo e promovê-lo se desenvolvem no capítulo seguinte. 
No terceiro capítulo, a ênfase recai na metodologia utilizada e a análise dos documentos consultados, em especial o PPCUB. A análise se deu por meio de documentos oficiais, da atuação do poder público local para a preservação da condição de Brasília como Patrimônio Cultural da Humanidade em face às ameaças, apontadas pela Unesco, que podem representar a perda do título. Para isso, consideramos as recomendações dadas pelo organismo internacional nos relatórios das reuniões do Comitê do Patrimônio Mundial, desde a obtenção da chancela. Em contrapartida, procuramos relacionar as ações tomadas pelo governo local em reflexo às recomendações recebidas. Dessa forma, procuramos extrair dos relatórios do Comitê os principais pontos que originaram as diretrizes para a preservação da área tombada, que, de forma inegável, se relacionam com o desenvolvimento urbano da cidade, sendo eles o PDOT e o PPCUB (ainda em fase de elaboração). Nesses dois documentos citados, procuramos nos ater essencialmente ao tratamento que o poder público dá ao patrimônio cultural e ao turismo como elemento possível da valorização do primeiro.

No processo de análise observa-se que a desarticulação dos órgãos governamentais na gestão do patrimônio cultural local resulta numa utilização precária desse patrimônio como recurso turístico. Essa ineficiência do uso do patrimônio para a atividade turística talvez esteja na não percepção pelos órgãos públicos de que a inserção do sujeito nesse processo é também fundamental para que a representatividade do patrimônio cultural possa refletir em ações de valorização e promoção desses bens. Por fim, ao nos reter na análise do PPCUB (ainda em construção), pode se observar ser esse uma alternativa possível para a valorização do patrimônio cultural local capaz de se tornar um incremento para o estímulo ao turismo em âmbito do Distrito Federal. 


\section{CAPÍTULO 1 - CONTEXTUALIZAÇÃO DO PATRIMÔNIO PEDRA E CAL}

Neste capítulo, abordamos a constituição do patrimônio de "pedra e cal" do Distrito Federal e analisamos a atuação do poder público no processo de manutenção, valorização e preservação dos bens culturais que expressam a história, memória e identidades locais. Ressaltamos, nesse contexto, como que Brasília obteve o título de Patrimônio Cultural da Humanidade, bem como as medidas tomadas para a manutenção da chancela concedida pela Organização das Nações Unidas para a Educação, a Ciência e a Cultura (Unesco), e como as ações governamentais podem incentivar o turismo local por meio da valorização do Patrimônio Cultural.

O Patrimônio será aqui entendido enquanto uma herança cultural, um legado passado de geração à geração, de capital importância para o entendimento das nossas raízes culturais. O patrimônio, palavra de origem latina (patri, pai + monium, recebido), é a designação do que está diretamente relacionado àquilo que foi herdado. Na concepção contemporânea, o termo ultrapassa o âmbito individual e familiar. Temos hoje que a noção do patrimônio é coletiva, onde o legado, seja ele histórico, artístico, natural ou paisagístico, se estende a toda uma coletividade, sendo que em alguns casos, à toda humanidade.

\subsection{Colecionismo, monumentos e monumentos históricos: o advento do patrimônio histórico}

Como diz Gonçalves (2009), mesmo que muitos estudos afirmem que a constituição do patrimônio, como representação simbólica de um grupo social, está vinculada ao processo de formação dos Estados nação no fim do século XVIII, o autor compartilha da percepção de que o patrimônio sempre esteve presente no mundo. As coleções de bens móveis e imóveis (o "colecionismo") antecedem os museus e refletem o processo de formação dos patrimônios, onde prevalece a ideia de seleção do que deve ser lembrado e do que deve ser esquecido.

Todo e qualquer grupo humano exerce algum tipo de atividade de colecionamento de objetos materiais, cujo efeito é demarcar domínio subjetivo em oposição ao outro (GONÇALVES, 2009, p. 26). 
Dessa forma, podemos caracterizar o patrimônio como o conjunto de elementos selecionados para que, ao longo do tempo, simbolizem características marcantes e representativas de uma época ou grupo social. Como define Oliveira (2008, p. 114),

\begin{abstract}
A noção de patrimônio confunde-se assim com a de propriedade herdada. $\mathrm{O}$ processo pelo qual se forma um patrimônio é o de colecionar objetos, mantendo-os fora do circuito das atividades econômicas, sujeitos a uma proteção especial e expostos ao olhar dos deuses ou dos homens. O valor desses objetos é determinado pelos mitos e pelas tradições.
\end{abstract}

Mas foi após a Revolução Francesa que a ideia de patrimônio surge como herança pública, no momento em que os bens do clero foram colocados "à disposição da nação" (CHOAY, 2006, p. 98), como sendo de propriedade coletiva. A partir de então, antiguidades, objetos sagrados e obras arquitetônicas passaram a carregar um valor histórico e afetivo para uma nação, sendo adotado o processo de nacionalização dos bens.

Françoise Choay (2006), afirma que o patrimônio histórico é aquele que está ligado a um passado comum, relacionado com a vida de todos, e esteve e está essencialmente representado pelas edificações. O patrimônio, portanto, se restringiria, por muito tempo, aos edifícios individuais, representantes da arqueologia e da história da arquitetura erudita, sejam eles considerados monumentos ou monumentos históricos.

Choay (2006) consegue nos mostrar onde houve a ruptura entre o que chamamos de monumentos e monumentos históricos. Para ela, o monumento é toda edificação mantida por uma comunidade para reverenciar um acontecimento ou rito a ser rememorado, pois "a especificidade do monumento deve-se precisamente ao seu modo de atuação sobre a memória" (CHOAY, 2006, p.18). Assim, atribuiu-se ao monumento, não somente a função de resgatar uma lembrança, mas também o papel de representar uma forma para despertar a memória sensível de seus apreciadores. O passado rememorado pelo monumento

(...) é localizado e selecionado para fins vitais, na medida em que pode, de forma direta, contribuir para manter e preservar a identidade de uma comunidade étnica ou religiosa, nacional, tribal ou familiar (CHOAY, 2006, p. 18).

Segundo Choay (2006), com o passar do tempo, a ideia de monumento ficou mais ligada ao efeito produzido pelas edificações, onde as técnicas de construção eram consideradas mais significantes do que a destinação original que formou o monumento. Dessa 
forma, houve uma transformação de seu significado com a extinção de sua função memorial, sendo no final do século XVIII que o conceito de monumento histórico se firma.

À medida que estas (as sociedades desenvolvidas) dispunham de técnicas
mnemônicas mais eficientes, aos poucos deixaram de edificar monumentos e
transferiram o entusiasmo que eles despertavam para os monumentos
históricos (CHOAY, 2006, p. 25).

Assim, o monumento histórico se distingue do monumento porque há na "criação" do primeiro uma intencionalidade e sua destinação é pensada a posteriori, como nos explica Choay (2009). São edificações escolhidas dentre tantas para representarem um momento histórico e estão essencialmente ligadas ao presente, diferentemente dos monumentos.

Mas só depois da $2^{\mathrm{a}}$ Guerra Mundial é que novas expressões de construir, como as obras arquitetônicas, foram consideradas como categoria de monumento histórico, pois passariam a representar uma herança a ser preservada, adquirindo também significado histórico.

Com a concepção de que o patrimônio adquiria um caráter nacional, houve na sua preservação a construção de uma relação direta com a preservação da memória, atribuindo a ele um significado histórico e afetivo. Com a intervenção estatal para o impedimento da destruição de monumentos, foi instituída a sua conservação para a preservação do patrimônio nacional. As medidas de conservação do patrimônio surgem especialmente para a manutenção do valor nacional que é atribuído a esse bem. Assim, a prática da preservação do patrimônio histórico passa a ser assunto de Estado quando ele passa a ser propriedade coletiva.

Le Goff (1990) afirma que foi acelerado o movimento de coesão das nações em torno de uma memória comum, que simulasse um fator de unificação, representado pelos monumentos. Dessa forma, as edificações passaram a ser o testemunho de um passado coletivo. É neles e através deles que estaria disponível para (re)conhecimento e apreciação o passado de um grupo social.

Dessa forma, o processo de tombamento passa a ser utilizado como o principal instrumento de preservação do patrimônio histórico. Porém, é no século XX que são estabelecidos os critérios para "não deixar escapar nenhum testemunho historicamente significativo" (CHOAY, 2006, p. 13). Como observa Costa (2012), a patrimonialização tem processo acelerado a partir da $2^{\text {a }}$ Guerra Mundial, com o intuito dos países devastados pelo conflito conservarem suas identidades. 
Urry (2001, p. 143-144) observa que há um "fascínio contemporâneo pela contemplação daquilo que é histórico ou daquilo que hoje é designado pelo termo tradição”. Nesse sentido, o autor observa que houve uma proliferação de museus, casas de tradição e estabelecimentos que celebrem o passado para atender, sobretudo, a demanda turística. "Quase todos os lugares e quase tudo do passado pode ser conservado" (URRY, 2001, p. 144).

Se nesse sentido, quase tudo pode ser conservado, houve a necessidade de estabelecer critérios para a institucionalização do que deveria ser eleito. Observamos que o turismo vem se tornando um elemento influente no movimento de patrimonialização, mas anterior a ele temos a utilização do patrimônio numa dinâmica relacional com a formação da identidade de uma nação, pois os bens culturais expressam as experiências históricas, as vivências de um povo, sejam elas étnicas, religiosas, étnicas e religiosas ou artísticas, políticas, dentre outras. Nesse sentido, a patrimonialização dos bens, de interesse de uma coletividade, ajudam a preservar a identidade da nação, pois têm inscritas neles as singularidades que diferenciam os povos um dos outros.

O conhecimento do processo de construção do patrimônio permite compreender sua importância como elemento na tentativa de constituição de identidade mesmo depois de tantos séculos.

Como afirma Oliveira (2008), os conceitos de memória, história e identidade se interrelacionam na abordagem do patrimônio, mas seus conteúdos foram modificados ao longo do tempo. Na construção dos Estados nacionais houve a exigência para que os cidadãos fossem os guardiões das tradições, que serviam de identidade cultural. Ter uma identidade representava, acima de tudo, pertencer a um país, a um território. A cultura, assim como o patrimônio, assumia, a partir da formação dos Estados modernos, uma vinculação direta com símbolos e manifestações culturais na busca pela "materialidade da ideia de nação" (OLIVEIRA, 2013, p. 766).

Com o fim dos Estados nação, as sociedades contemporâneas necessitaram da história como instrumento para ressignificar suas identidades, pois a busca pela identidade "mais estável" tornou-se uma necessidade devido às rupturas e hibridações impostas pela globalização.

Hall (2011) afirma que o indivíduo atual passa pelo o que ele chama de crise de identidade, que seria o processo de mudança das referências que davam ao indivíduo a 
estabilidade no mundo social. Tal processo seria provocado pelo deslocamento das estruturas e processos centrais da sociedade moderna. A discussão em torno da identidade ocorre pelo surgimento de novas identidades que fragmentam o indivíduo. É o declínio das velhas identidades, aquelas do sujeito unificado, que antes estabilizaram o mundo social.

Um tipo diferente de mudança estrutural está transformando as sociedades modernas no final do século XX. Isso está fragmentando as paisagens culturais de classe, gênero, sexualidade, etnia, raça e nacionalidade, que no passado, nos tinham fornecido sólidas localizações como indivíduos sociais. Estas transformações estão também mudando nossas identidades pessoais, abalando a ideia que temos de nós próprios como sujeitos integrados. Esta perda de um 'sentido de si' estável é chamada, algumas vezes, de deslocamento ou descentração do sujeito. Esse duplo deslocamento descentração dos indivíduos tanto de seu lugar no mundo social e cultural quanto de si mesmos - constitui uma 'crise de identidade' para o indivíduo (HALL, 2011, p. 9).

Hall (2012) ainda define a identidade como um jogo de poder, onde a sensação de pertencimento é uma ligação à história, e seu surgimento se origina da imaginação, do simbólico e também da memória que se preza.

Stuart Hall infere que o indivíduo contemporâneo ao nosso tempo assume distintas identidades em diferentes momentos. Para ele, a identidade é algo a ser construído e não descoberto. Para Baumann, "a ideia de 'identidade', e particularmente de 'identidade nacional', não foi 'naturalmente' gestada e incubada na experiência humana como um 'fato da vida" (BAUMANN, 2005, p. 26), ela foi criada de forma a manter uma coesão por meio de seus modos de vida, dialetos e tradições.

Os bens simbólicos são utilizados enquanto constituintes de identidade, e também como objetos de ação política para inserir as cidades no rol de destinos turísticos. Mas a questão envolve, ainda, a quem estaria creditado o papel de possuir a memória e o esquecimento de uma coletividade, pois os silêncios da história revelam os mecanismos de manipulação da memória coletiva. Ou seja, a memória de uma coletividade, tal como é desenvolvida pelas nações, faz parte de um projeto político que tem como fito representar a identidade de um povo. Portanto, dada essa característica, os bens culturais dos povos são selecionados, a partir de determinados critérios, para constituir sua memória. Nesse sentido, muito da cultura e história de um povo acaba caindo no limbo do esquecimento, por não ser, 
na visão dos guardiões institucionalmente oficializados pelos Estado, significativo e representativo para a imagem do país que se quer construir.

Sendo assim, a memória, como instrumento de poder, passa a atribuir ressignificações a eventos passados para justificar a origem desses elementos.

\begin{abstract}
A memória é um elemento constituinte do sentimento de identidade, tanto individual como coletiva, na medida em que ele também é um fator extremamente importante do sentimento de continuidade de coerência de uma pessoa de um grupo em sua reconstrução de si (POLLAK, 1992, p. 204).
\end{abstract}

A apropriação do termo patrimônio, no senso comum, reflete a ideia de herança e propriedade, tanto que as designações estão presentes no cotidiano quando falamos em patrimônio genético, patrimônio econômico, patrimônio cultural etc. Como diz Gonçalves (2009, p. 25) "parece não haver limite para o processo de qualificação dessa palavra", quando designa o patrimônio como uma categoria de pensamento habitual ao mundo ocidental.

Hartog (2006) afirma que a condição básica do patrimônio é o seu caráter histórico, de ressignificação do passado, mas observa-se, no final do século XX, o que o autor chama de patrimonialização galopante, onde é manifesta a influência do tempo presente na construção do patrimônio, em um momento onde existe a memória obsessiva por tudo.

A ideia de patrimônio se ampliou com o passar dos anos. Foram incluídos nas listas oficiais elementos de representação popular, que não tinham seu reconhecimento anteriormente. A valorização do patrimônio "pedra e cal", representado pelos monumentos e edificações espetaculares, passa a dividir lugar com outros elementos de memória, como os vestígios da história local (a literatura, tradições orais, saberes e criações coletivas), antes negligenciados.

A chamada patrimonialização de um número cada vez maior de bens materiais e imateriais pode ser considerada como um sinal de acentuação do presentismo vivido pela sociedade pós-moderna, conforme abordado por Francóis Hartog (2006). Para este autor, a sociedade vive um momento entre a amnésia e a vontade de nada esquecer. Nesse sentido, a patrimonialização dos bens culturais é uma forma de manter viva a memória das experiências humanas que são eleitas como significativas da identidade de um povo. Na mesma direção, Le Goff (1990) também nos diz que há a existência do medo da perda de memória, de uma amnésia coletiva e, para combatê-la, a memória também tornou-se um dos objetos de 
consumo das sociedades contemporâneas. Mas a memória coletiva não seria apenas uma conquista, ela se configura também como um instrumento e um objeto de poder, através do qual as sociedades tentam garantir a preservação, manutenção e valorização do seu legado histórico e cultural.

Como afirma Canclini (2012, p. 72)

Embora ocasionalmente o patrimônio sirva para unificar uma nação, as desigualdades em sua formação e apropriação exigem estudá-lo também como espaço de disputa material e simbólica entre os setores que a compõem.

Porém, com o intuito de preservar a identidade cultural e salvaguardar os elementos de referência histórica, temos a difusão da ideia de que somente pelos mecanismos de tombamento ou registro é possível preservar o patrimônio coletivo. "Discute-se a presença ou ausência do patrimônio, a necessidade ou não de preservá-lo, porém não se discute sua existência" (GONÇALVES, 2009, p. 28). O desempenho do poder público, que é atuante sobre o patrimônio cultural do Distrito Federal, tem na valorização dos patrimônios, talvez, o principal elemento para que haja a sensibilização da sociedade quanto ao seu acervo cultural. E a partir dessa valorização, com a aproximação dos residentes e turistas desses bens, é possível viabilizar seu papel econômico e funcional, inclusive para o turismo, visto que, em nossa contemporaneidade, é crescente o número de pessoas que se interessam pelo turismo cultural que, sem dúvida, contribui para o desenvolvimento social e econômico das localidades onde esses bens se encontram.

Assim, o processo de tombamento produzirá efeitos irrelevantes enquanto não atrelar à função de proteger ações que permitam sua apropriação simbólica. Como observa Fonseca (2009, p. 67)

Reduzir o patrimônio cultural de uma sociedade às expressões de apenas algumas de suas matizes culturais - no caso brasileiro, as de origem europeia, predominantemente a portuguesa - é tão problemático quanto reduzir a função do patrimônio à proteção, que evidentemente, representa também um ônus para a sociedade e para alguns cidadãos em particular. Para que essa função se cumpra, é necessário que a ação de 'proteger' seja precedida pelas ações de 'identificar' e 'documentar' - bases para a seleção do que deve ser protegido -, seguida pelas ações de 'promover' e 'difundir', que viabilizar a reapropriação simbólica e, em alguns casos, econômica e funcional dos bens preservados. 
Se o patrimônio é um bem coletivo, deve estar disponível para o conjunto social, mesmo que sua fruição seja individualizada.

A ideia de deixar o passado ao nosso alcance sempre que possível por meio da preservação de coleções, obras artísticas, monumentos e das tradições nos parece ser uma tentativa de reconstruir a história da humanidade, onde a imutabilidade seria o conservante desses elementos.

E para preservar tal patrimônio, medidas são tomadas devido a seu valor nacional, o que ele representa afetivamente. Nesse sentido, cresce a atuação do Estado, à medida em que o patrimônio torna-se legado de todos, adquirindo uma dimensão de universalidade.

Como nos diz Oliveira (2008, p. 114),

[...] os chamados patrimônios históricos e artísticos têm, nas modernas sociedades ocidentais, a função de representar simbolicamente a identidade e a memória de uma nação. O pertencimento a uma comunidade nacional é produzido a partir da ideia de propriedade sobre um conjunto de bens: relíquias, monumentos, cidades históricas, entre outros.

A produção de um lugar de patrimônio na busca de constituir a identidade local passa pela ressignificação da cidade. As identidades, como afirma Hall (2012), precisam ser compreendidas como produção em locais históricos e institucionais, pois elas estão dentro e não fora do discurso. E é preciso entender os efeitos sociais dos discursos. Quando Woodward (2012) diz que a identidade está vinculada a condições sociais e materiais, a autora explora a possibilidade dos efeitos reais, quando um grupo socialmente excluído deixa de ter vantagens, inclusive materiais. Portanto, a constituição do patrimônio cultural de uma cidade, implica em assumir a representação a partir de uma falta, ou seja, o jogo de poder que se estabelece para constituir a identidade que se quer assumir, como seremos apresentados aos outros. Sobretudo, quando observamos que há uma limitação nos critérios utilizados para os instrumentos oficiais de proteção para representatividade da diversidade civilizatória.

Fonseca (2009) nos responde que isso realmente ocorre, pois mesmo os organismos internacionais como os representantes nacionais, responsáveis por chancelar o patrimônio cultural oficial, não se distanciam de uma noção tradicional de patrimônio histórico e artístico. Canclini (2012, p. 71) corrobora com a autora quando afirma que as políticas estatais voltadas para o patrimônio cultural 
[...] fingem que a sociedade não está dividida em classes, gêneros, etnias e regiões, ou sugerem que essas fraturas não tem importância diante da grandiosidade e respeito ostentados pelas obras patrimonializadas.

A valorização simbólica de Brasília está atrelada à sua concepção de modernidade. A Capital que carregou o papel de representar o ideário de Brasil moderno, significando a ruptura com o país tradicional. Desse ponto de vista, Brasília seria então o espaço capaz de conciliar o país com seu projeto desenvolvimentista. E essa nova identidade nacional de um país moderno e progressista, representada pelas obras monumentais que formam o centro político-administrativo da capital atraem visitantes do mundo inteiro.

Mas como afirma Hall (2012), diferente do que pensamos, a identidade não é representada por invocações de um passado histórico, o que de fato acontece é a utilização de recursos desse passado (história, linguagem e cultura) para construir uma identidade desejada. Os bens simbólicos tombados se inserem nesse cenário, como reivindicação de determinados grupos na tentativa de manter viva a sua memória e não perder seus referenciais identitários. Assim, no jogo de selecionar e excluir elementos representativos, sejam eles monumentos (históricos ou não), não há como escapar do favorecimento proposital para a salvaguarda e rememoração de elementos, que vimos a chamar de patrimônio cultural.

Na constituição do patrimônio cultural "no" Distrito Federal, entre as esferas distrital e federal, podemos perceber uma diferença no tratamento dos bens inseridos nas listas de tombo. No Instituto do Patrimônio Histórico e Artístico Nacional - Iphan, para o processo de tombamento, foram analisadas que são as edificações representativas da arquitetura moderna, em sua maioria, que privilegiam a monumentalidade, que compõem seu inventário. Já no âmbito do Distrito Federal, a constituição do patrimônio cultural se apresenta mais heterogênea, demonstrando a influência da iniciativa popular nesse processo, resgatando raízes históricas importantes.

Para Nunes (2005, p. 22), as imagens construídas pelas representações permanecem ou se modificam de acordo com o caminho histórico, ou seja, de acordo com as práticas sociais dos diferentes grupos que vivem a cidade no cotidiano.

Se as representações são elementos de todas as culturas, como afirma Pesavento (2006, p. 49), isso decorre porque “... os homens elaboram ideias sobre o real, que se traduzem em imagens, discursos e práticas sociais que não só qualificam o mundo como orientam o olhar e a percepção sobre a realidade". Seria através das imagens de representação coletiva que o mundo é apropriado pelo indivíduo. Isso porque o mundo que vemos é 
“construído socialmente pelo pensamento". "Esse é o nosso 'verdadeiro' mundo, mundo pelo qual vivemos, lutamos e morremos" (PESAVENTO, 2006, p. 50). Mas não apenas na dimensão hegemônica, elitista ou oficial que esse sistema de imagens coletivas é construído. O indivíduo comum também tem um papel na construção dessas imagens através da história, à medida que é por essa representação coletiva que ele consegue dar significado às coisas.

Assim, cultura e representações, tal como a sensibilidade, não podem estar
distantes do conceito de memória. Do mesmo modo como a história é a
narrativa que presentifica uma ausência no tempo, a memória também
recupera pela evocação, imagens do vivido. É a propriedade evocativa da
memória que permite a recriação mental de um objeto, pessoa ou
acontecimento ausente. E, neste ponto, é preciso considerar que todos nós
temos um museu imaginário de imagens, transmissoras de uma herança do
passado, veiculadas pela memória individual, forjada de acordo com a
memória social (PESAVENTO, 2006, p. 51).

Desse modo, as discussões sobre o patrimônio cultural deveriam passar a girar em torno dos interesses de diversos segmentos sociais e suas representações, pois eles podem ser traduzidos como o desejo de apropriação desse patrimônio, tanto nos seus aspectos simbólicos, quanto físico-espaciais. Essa apropriação, portanto, implicaria na participação ativa que colocaria o sujeito como parte do processo decisório, no planejamento e na implementação de instrumentos voltados à escolha, gerência e preservação do patrimônio cultural tombado. A conexão e a apropriação que se estabelece entre os indivíduos e os símbolos culturais acontece devido à sua condição de ser histórico, pois a cultura, assim como o turismo e o patrimônio representam práticas sociais.

Como defende Fonseca (2009, p. 72-73), a ampliação da noção de patrimônio cultural foi mais um dos efeitos da globalização, "na medida em que ter aspectos de sua cultura, até então considerada como tosca, primitiva ou exótica, reconhecidos como patrimônio mundial contribui para inserir um país ou um grupo social na comunidade internacional, com benefícios não só políticos, mas também econômicos". O conjunto dos bens culturais de um povo, valorizado enquanto patrimônio, tem, por meio da apropriação do turismo, uma possibilidade de desenvolvimento econômico, porque é um atrativo que movimenta pessoas e, por conseguinte, capital financeiro que contribui para o desenvolvimento local. 


\subsection{Patrimônio Cultural e Turismo}

\subsubsection{Concepções sobre o turismo e sua relação com o patrimônio cultural}

O turismo foi considerado por tempos, sobretudo por seu aspecto econômico, sendo tido como uma fonte geradora de divisas e de potencial apelo ao desenvolvimento de cidades outrora "degradadas", mas que apresentam riqueza cultural e histórica inscritas em seus espaços, em seus prédios, nos saberes locais, os quais, por meio de políticas públicas, tornaram-se atrativos turísticos. Como há décadas atrás, o turismo foi incentivado em cidades devastadas por guerras visando sua recuperação econômica. Essa concepção é propagada até os dias de hoje, pois apoia-se, quase que exclusivamente, em estatísticas de governos e órgãos oficiais sobre o fluxo de visitantes. Mas no final da década de 1960, ao turismo vincularam-se os impactos negativos que eram provocados nas regiões visitadas (nos âmbitos cultural, econômico e natural), revelando por parte dos atores envolvidos a falta de planejamento no seu desenvolvimento. Esses impactos ficaram cada vez mais evidentes com a explosão do turismo de massa no mundo ocidental. Esses dois momentos do entendimento do turismo são descritos por Jafari (1994) como a Plataforma defensora: el bien e a Plataforma de advertência: el mal, respectivamente ${ }^{1}$.

Para Molina (2003), a evolução do turismo segmenta-se em três grandes fases: 1) o pré-turismo, cujo expoente máximo é o Grand Tour ${ }^{2}$; 2) o turismo industrial, caracterizado pela expansão do turismo de massa; 3) o pós-turismo, que constitui, para ele, um novo paradigma na história do turismo. Como conjunto da vida social, o turismo foi influenciado pelo ambiente, pelo desenvolvimento tecnológico e seus desdobramentos. Assim, o pósturismo de Molina apresenta como características a não necessidade do deslocamento do local de residência e a inexistência do contato com indivíduos das comunidades locais. Além disso, há a percepção de que os cenários naturais oferecidos são transformados pela aplicação da

\footnotetext{
${ }^{1}$ Jafari continua sua análise sobre a descrição da evolução do entendimento do turismo. $\mathrm{O}$ autor observa que na década de 1970, começa a conviver com as concepções anteriores a perspectiva de sustentabilidade, quando observando que ao serem adotadas novas formas e alternativas de turismo, tendo como foco os habitantes das regiões visitadas e os atrativos locais (e não exclusivamente o turista). Assim, o turismo beneficia os anfitriões e os turistas com equidade, sendo seu melhor exemplo o Ecoturismo (Plataforma de adaptation: el como). Ele ainda descreve o que chama de Plataforma basada en el conocimiento: el porqué que seria o esforço de pesquisadores e acadêmicos na formação de um corpo de conhecimento científico sobre o turismo, onde tentam dar ao turismo um tratamento holístico, não somente considerando seus impactos e formas, mas o encarando em sua totalidade, sendo preciso criar novas associações entre ciências e disciplinas que tratam do fenômeno turístico.

${ }^{2}$ Viagens destinadas a grupos de pessoas abastadas (nobreza e burguesia), cujo objetivo era observar galerias, museus, e atrativos culturais, visando a instrução e o enriquecimento cultural.
} 
tecnologia, como também a atividade não seria mais determinada pelos recursos naturais ou culturais da região de destino, pois atrativos poderiam ser desenvolvidos sem a integração desses elementos.

As concepções de Molina não se aplicam a todos os destinos turísticos na sequência apresentada, mas certamente o autor chegou a essa análise pelos casos emblemáticos que podem exemplificá-la. Pode-se dizer que, para ele, a concepção de pós-turismo coincide com a condição da pós-modernidade, onde a virtualidade é imperiosa.

Mesmo admitindo a virtualidade ser uma das condições do pós-turismo e da pósmodernidade, o novo entendimento do turismo demanda por uma grande quantidade de informação, cada vez mais complexa e exigente, como também o turista se dispõe, por outro lado, a ter um papel ativo, assumindo o papel de protagonista em suas viagens.

É por isso que analisaremos o turismo como um fenômeno sociocultural de valor simbólico, onde as práticas realizadas tem maior significado pelo seu valor afetivo, mas também iremos levar em conta o seu valor de troca, pois o fenômeno da patrimonialização é incentivado cada vez mais pelo potencial econômico que adquirem as paisagens.

Canclini (2012, p. 74), quando observa dois tipos de uso do patrimônio, o desenvolvimento urbano e os meios de comunicação, afirma que esses "talvez sejam hoje os processos mais influentes no conhecimento e na valorização dos bens culturais”. Para o autor, é por meio dos meios de comunicação de massa que é difundido para milhões de pessoas que nunca tenham visitado determinado destino, o patrimônio cultural de uma localidade. É como se a imagem prévia já representasse uma viagem e ao se deslocar fisicamente ao destino, isso se tornasse uma volta ao passado. É nesse sentido que Canclini atribui ao uso do patrimônio pelo turismo uma distorção de seu sentido original, quando, para atender aos desejos desse turista que ainda não chegou, "cada edifício ou objeto patrimonial estivesse destinado a permanecer intacto" (CANCLINI, 2012, p. 77).

Assim, desde a obtenção da chancela, o Conjunto Urbanístico de Brasília, que inclue todo o conglomerado urbano tombado, já teve que passar por avaliações para manutenção do título. A fim de reordenar essa área, foi estabelecido o Plano de Preservação do Conjunto Urbanístico de Brasília - PPCUB, que se trata de um plano que visa sistematizar e rever a legislação urbanística, além de apresentar propostas para o desenvolvimento sustentável do sítio urbano tombado, que retomaremos mais adiante. 
Como observam Gastal e Moesh (2007), assim como o viajante, o sujeito tem novas demandas culturais, ele não se contenta em apenas conhecer lugares incomuns, mas está motivado a vivenciar experiências simbólicas, onde haja uma carga de entrega pessoal e subjetividade afetiva nesse processo. Podemos dizer que o turismo é a busca do diferente de si, a procura por novas identidades.

Gastal e Moesh (2007) preconizam que o fenômeno contemporâneo do crescimento das cidades aponta para um caminho contrário à padronização. Quando se esperava o desenraizamento das tradições ligadas ao território, no rumo à homogeneização das sociedades, notam-se espaços de resistência às identidades universalistas. Nesse sentido, o desenvolvimento incessante das metrópoles é propício ao surgimento de espaços de multiplicidade cultural, de um terreno heterogêneo onde é apresentada uma variedade de padrões e valores culturais, tornando as cidades em espaços de fragmentação e de diversidade.

Como aponta Canclini (2003, p. 20)

[...] não se pode falar de cidade moderna, pois às vezes está deixando de ser moderna e de ser cidade. O que era um conjunto de bairros se espalha para além do que podemos relacionar, ninguém dá conta de todos os itinerários, nem de todas as ofertas materiais e simbólicas desconexas que aparecem.

Mas diante disso, não podemos deixar de ressaltar que o patrimônio cultural de uma localidade não pode ser visto apenas como um potencial atrativo turístico, mas ele deve ser relembrado como um lugar de memória, pois cada peça de museu, cada monumento de uma cidade, cada tradição local tem um valor simbólico para aqueles que os elegem enquanto representativos de sua cultura.

O contato entre turistas e residentes, entre a cultura do morador e a cultura do turista, desencadeia um processo pleno de contradições, mas que, contraditoriamente, provoca o fortalecimento do próprio visitante que, na alteridade, se redescobre. Assim, o turismo possibilita ao indivíduo a oportunidade de ir ao encontro do outro. Sendo que ao chegar à comunidade de destino, o turista que traz em sua bagagem sua história e sua cultura já sedimentadas, se defronta com o outro, o diferente. Mas o outro também possui sua cultura que lhe confere uma identidade diferente das demais. É nesse momento de encontro entre um e o outro que suas identidades são reafirmadas. Relembrando Hall (2001), seria apenas uma de suas identidades, pois ser turista é apenas uma das várias identidades que o indivíduo carrega. 
Como característica intrínseca do turismo, a procura pelo diferente, pelo particular, continua sendo o componente fundamental da viagem contemporânea. Porém, essa busca por experiências significativas passa pelo encontro de elementos simbólicos das identidades culturais, como seu patrimônio.

Desde o advento do patrimônio, não era apenas para a comunidade circundante, herdeira daquela história, que os monumentos interessavam. Os viajantes também apresentavam certo fascínio por essas edificações, testemunhas do tempo. Desde o fim da Idade Média, os monumentos já despertavam entusiasmo para a contemplação. A partir do século XVII, como afirma Urry (2001), o Grand Tour, que tinha como clientela a aristocracia e a nobreza, exercia um papel fundamental na educação da classe inglesa que, naquele momento, buscava conhecimento. Mas à medida em que crescia a ideia de monumento, novos interesses atraiam dos viajantes eruditos.

Ao sabor de seus itinerários, esses viajantes não se deixavam mais absorver inteiramente pela pesquisa dos monumentos pertencentes às civilizações da alta Antiguidade ou Antiguidade Clássica; eles se familiarizam também com culturas até então ignoradas, negligenciadas ou desprezadas (CHOAY, 2006, p. 67).

O turismo como experiência social é poderoso para o imaginário coletivo. Isso porque, nessa experiência, são colocadas em jogo ideias como a socialização e o consumo de bens simbólicos.

O imaginário compõe-se de representações sobre o mundo do vivido, do visível e do experimentado, mas também sobre os sonhos, desejos e medos de cada época, sobre o não tangível nem visível, mas que passa a existir e ter força de real para aqueles que o vivenciam (PESAVENTO, 2006, p. 14).

Observamos que a relação entre o patrimônio e o turismo se estabelece ainda no século XVII. O turismo passa assim a ser uma ponte para a satisfação dos admiradores dessas obras, como também, e através dessa experiência, são ampliadas as possibilidades de destinos e monumentos a serem considerados.

Le Goff (1990) aponta que, a partir do século XIX, com o aparecimento de novos elementos de memorização, os monumentos e placas comemorativas surgem como testemunhos de fatos importantes e "inesquecíveis" no mesmo tempo em que, impulsionado pelo turismo, o comércio de souvenirs se alavanca. 
O patrimônio é um recurso para a prática do turismo, assim como a paisagem também o é, como afirma Castro (2002), e ambos carregam intrinsecamente um valor social. A autora nos diz que a paisagem constitui além de referência visual, uma representação, uma identidade, adquirindo tanto valor de uso como valor de troca, utilizados pelo turismo. Entendamos paisagem não apenas como a natureza, mas também como aquela oferecida pela intervenção humana, que lhe atribui valor simbólico. Sob essa ótica, podemos conceber o patrimônio cultural como um elemento integrante da paisagem das cidades, na medida em que ele é representação das experiências humanas de significativo valor histórico e social.

Porém, como afirma Castro (2002), a utilização das paisagens (e do patrimônio) como recurso turístico não é apenas o resultado do estímulo provocado por uma publicidade eficiente, mas decorre também do que elas evocam em quem as recebe. A conexão do indivíduo com o espaço que habita, transita ou visita se faz pela apropriação de símbolos e significações expressas pelos elementos culturais presentes nesse ambiente. Geertz (1989), ao se afastar de um conceito simplificado de cultura, faz referência a Max Weber, ao afirmar que o homem é um animal amarrado a teias de significados construídos por ele, sendo que a cultura representaria essas teias e suas análises. A cultura, portanto, não pode ser concebida como uma realidade dada, como uma estrutura de significados estabelecidos, pois o que importa é o que se transmite com sua ocorrência, caso contrário seria considerá-la de forma reduzida.

A constituição do patrimônio oficializado do Brasil apoia a ideia dos intelectuais tradicionais que, segundo Ortiz (2012), insistiam na preservação das expressões e manifestações do passado. A cultura brasileira era vista como um conjunto de valores (espirituais e materiais) acumulados através do tempo. Para o autor, por muito tempo no Brasil, a cultura era sinônimo de patrimônio e deveria, por isso, ser preservada. Esse comportamento foi "o princípio que orienta toda uma política de preservação e defesa dos bens culturais" (ORTIZ, 2012, p. 96).

Pesavento observa que cultura e representações não podem ser dissociadas do conceito de memória, pois é esta que "recupera pela evocação, imagens do vivido" (PESAVENTO, 2006 , p. 50). É por esse atributo que é possível a rememoração do ausente. O patrimônio também passa a ter força para aqueles que o vivenciam, pois possui essa propriedade evocativa da memória.

Faria (2009), em sua análise da relação que se estabeleceu entre a inclusão de Brasília na Lista do Patrimônio Cultural e o desenvolvimento do turismo na capital, afirma que 
Sem dúvida, o patrimônio urbanístico, arquitetônico e paisagístico de Brasília é merecedor do seu título de patrimônio cultural da humanidade. Entretanto, o patrimônio não pode ser considerado somente em sua acepção palpável. É também um complexo sistema de relações do ser humano com o tangível e o intangível que gera uma rede de significados e tem a capacidade de transformar os bens materiais e imateriais de uma cidade em um manifesto de identidade e cidadania (FARIA, 2009, p. 260).

Ao adquirir a concessão de cidade com a maior área tombada do mundo e sendo o primeiro bem contemporâneo a merecer a distinção de Patrimônio Cultural da Humanidade (DISTRITO FEDERAL, 2012, s/n), Brasília entra no rol dos destinos turísticos que possuem o prestígio do tombamento. O conteúdo simbólico da paisagem da cidade passa pelo diferencial atribuído à Brasília, essencialmente, por seu projeto arquitetônico e urbanístico. Mas como Castro (2002, p. 128) nos diz, “embora a proliferação de imagens produzidas pela publicidade seja importante, o seu efeito sobre as decisões individuais se dá em função de imagens prévias e muito mais profundas, constituídas e valorizadas durante gerações”. Como afirma Choay (2006), os elementos arquitetônicos servem à imagem midiática das cidades, dos quais se tornam o emblema e o símbolo. Os bens simbólicos são utilizados enquanto objeto de ação política para inserir as cidades na lista desses destinos turísticos. Assim, observamos a divulgação da Capital, tanto pelos órgãos governamentais, bem como pelas empresas de turismo a recorrente referência à cidade como exemplo máximo da modernidade, com a ideia de "cidade-monumento", construindo, dessa forma, o diferencial competitivo de Brasília. Atentando para a corrida para inscrição nas listas de tombo, Choay (2006, p. 108) define assim esse movimento em âmbito internacional

(...) na esfera estatal, o número de monumentos inscritos na lista do patrimônio mundial tende a se transformar num índice de prestígio internacional e a se tornar objeto de disputa, muitas vezes sem que os critérios de seleção dos bens patrimoniais sejam entendidos pelos países interessados.

Assim, vemos que a utilização do patrimônio como recurso turístico traz intrinsecamente as particularidades desse patrimônio como elemento diferencial. Dessa forma, observamos que o desenvolvimento do turismo também aponta para a valorização da regionalização cultural, uma vez que dá visibilidade aos aspectos culturais locais, ou seja, à alteridade inscrita nos bens que compõem o conjunto do acervo cultural que expressa a identidade de um povo. 


\subsection{O retorno ao local}

Com a mudança de paradigmas da pós-modernidade, acarretadas por transformações como o crescimento econômico, social e tecnológico mundial acelerados no século $\mathrm{XX}$, colocou-se em destaque no centro das discussões nas sociedades contemporâneas que apontam novas tendências para seu desenvolvimento socioeconômico, a valorização dos aspectos regionais e locais. Como afirma Maffesoli (2004), o indício da heterogeneização galopante é tão presente na pós-modernidade que o retorno ao "local" (localismo) é uma das marcas da época. Para o autor, "nas selvas de pedra que são as megalópoles contemporâneas, a tribo desempenha o papel que lhe competia na selva stricto sensu" (MAFFESOLI, 2004, p. 23.

A globalização apresentou desdobramentos inesperados quando se observou que não houve a sobreposição inexorável de valores universalistas ou globais, ou seja, como afirma Hall (2011), o ressurgimento do nacionalismo e de outras formas de particularismo no final do século XX, ao lado da globalização e a ela intimamente ligado, constitui uma reversão notável, com implicações inusitadas. Como observa o autor, nenhuma ideologia previa que o apego ao local e ao particular seria consequência da pós-modernidade, já que se preconizava que esses valores seriam substituídos gradualmente por identidades mais racionais e universalistas, sobrepondo-se às expressões tradicionais.

Nesse sentido, o desenvolvimento do turismo também aponta para a valorização da cultura regional e local, apresentando características singulares para serem usadas como mecanismos de diversificação e de exclusividade para seu incremento, incluindo-se aí o patrimônio cultural. É por meio do movimento chamado de patrimonialização que procura-se alcançar destaque no mercado turístico nacional e mundial, concedendo status aos destinos que carregam a chancela oficial.

Com a chamada turistificação do patrimônio, observamos que o movimento de universalização do patrimônio cultural não é desprovido de ideologia. Pois, como nos diz Costa (2012), a ideia de universalidade surge da necessidade de dominação de um grupo hegemônico, onde as ideias universais impostas devem ser apresentadas como legítimas.

Essa desigualdade está ligada, na verdade, ao poder de atuação/persuasão político-econômica de cada país signatário, uma vez que identificamos uma espacialização desequilibrada do Patrimônio Mundial, cuja distribuição dos 
bens esboça desigualdade perante uma humanidade que se diz e se quer constituída e integrada (COSTA, 2012, p. 125).

Quando Nunes (2005, p. 26) afirma que “o patrimônio, enquanto um bem cultural deve ser visto a partir de disputas entre grupos, cada qual tentando garantir sua continuidade, pois tais bens abrigam valores e significados que os distinguem, atribuindo-lhes identidade" ele corrobora com o que Costa (2012) defende como o apoderamento territorial soberano, sendo esse a legitimação dos interesses da classe dominante quando essa os apresenta como sendo de todos e, no caso de um bem cultural, isso se dá quando é promovida sua universalização. Além disso, Costa (2012) ainda afirma que a valorização econômica atribuída ao patrimônio cultural, aspecto relevante para a concessão da chancela pela Unesco, é fator essencial para ações que norteiem práticas para o reconhecimento dos lugares que abrigam esse patrimônio, inclusive para o exercício do turismo. A caracterização dos bens culturais em escalas cada vez maiores evidencia a corrida para a distinção dos lugares na busca de atribuir-lhes uma característica única e singular, diferenciando-os no mercado da grande oferta de destinos turísticos, continua o autor.

\subsection{Os órgãos gestores do patrimônio cultural brasileiro}

Desde a Convenção do Patrimônio Mundial da Unesco, em 1972, alerta-se que o patrimônio cultural encontra-se cada vez mais ameaçado, seja pelos fatores naturais, econômicos ou sociais e, sob esse aspecto, insere-se o turismo, quando este, em função da demasiada exploração econômica do patrimônio, não atua de forma consciente e sustentável.

Portanto, não são apenas as ameaças preconizadas pelo turismo em ambientes protegidos que provocariam a descaracterização dos bens culturais. Como aponta Choay (2006), sempre se observou as ações de vandalismo privado, ideológico ou econômico (quase sempre praticadas dentro da legalidade) tornando-se necessária a ação dos órgãos de proteção para a preservação desse patrimônio. Dessa forma, as ameaças impostas no mundo contemporâneo exigem que sejam assumidas novas posturas diante do patrimônio cultural, sejam elas adotadas pelos organismos governamentais ou pela população local.

Para salvaguardar o patrimônio cultural do país foi preciso antes saber o que era representativo da identidade nacional. Segundo Ortiz (2012), no caso brasileiro, sempre houve um consenso para afirmar que o país apresentava uma identidade particular, diferente dos 
outros países, mas no processo de construção de tal identidade, percebe-se o embate dos intelectuais na tentativa de dizer qual é a verdadeira identidade nacional. Tal identidade estaria ligada à construção do Estado brasileiro, havendo, ao longo da história, uma ligação entre a cultura e o poder político do país.

Estudiosos e intelectuais delimitaram essa trajetória desde o tempo do Império, época em que foi criado o Instituto Histórico e Geográfico Brasileiro - IHGB, em 1836. Assim, viagens pelo país buscavam inventariar as terras brasileiras, com a exploração da fauna e flora regionais, sendo essas consideradas exemplos de superioridade do país e a fonte de sua singularidade. Como cita Oliveira, "foram eles que apresentaram o Brasil aos brasileiros" (OLIVEIRA, 2008, p. 35). A autora também afirma que a identidade nacional construída pela monarquia brasileira tinha como traço predominante a natureza exótica. O IHGB, criado por Pedro II, nasceu com a preocupação em definir as fronteiras brasileiras, mas também empenhava-se em reconhecer a heterogeneidade da população indígena brasileira. A população negra não era considerada ainda como uma matiz. As pesquisas realizadas pelo Instituto tinham um caráter histórico e visavam atribuir uma legitimidade ao território do novo país, como também apresentá-lo como uma nação. Era uma preocupação que houvesse o reconhecimento europeu, pois temia-se que houvesse ocupação territorial, como acontecia na África à época. Foi a primeira tentativa de registro da identidade nacional. Nesse contexto, o IHGB pregava a organização e a definição dos valores nacionais. Os intelectuais que lá atuavam buscavam implementar uma política de valorização cultural.

Para Oliveira (2008), foi no início do período republicano que se apresentou o confronto de duas correntes divergentes para a defesa da identidade cultural, sendo o viés que gostaria de romper com o passado colonial e aquele que defendia a continuação das tradições portuguesas. E é nesse período que as questões de identidade da cultura brasileira passam a receber maior atenção das ações políticas brasileiras.

No início do século XX, é que se nota o empenho dos intelectuais, quase sempre ligados ao Estado, de definir a "verdadeira" identidade nacional, inclusive sem negar a influência da população negra na formação cultural brasileira.

Nesse período, com a influência do pensamento positivista, o Império representava o atraso. O país deveria perseguir o progresso. Para os defensores dessa filosofia, a natureza deixava de ser referência de originalidade para estar a serviço do progresso brasileiro. 
Outro destaque do período, foi a propagação da ideia de que ao conhecer o passado seria possível a construção do um novo futuro, desenhado no cenário do desenvolvimento econômico, social e cultural que se desejava para o país. Nesse contexto, a proteção de nossa herança histórica e cultural, foi imprescindível nessa ação do Estado de construção da memória nacional representada pelo conjunto dos bens patrimoniais que expressam a identidade nacional. Estava definido que "o rito do tombamento era a forma de sacralizar o passado" (OLIVEIRA, 2008, p. 123).

\subsubsection{Sphan/Iphan}

No início do século XX, com o processo de modernização das cidades, houve uma repulsa pela expressão cultural daqueles que não pertenciam às elites. Motivado pelo sentimento de progresso, o Brasil procurava se enquadrar no mapa mundial como uma nação próspera, ligada ao desenvolvimento.

As tradições populares da população pobre eram identificadas com a barbárie, a selvageria, o mundo primitivo, podendo receber no máximo a classificação de comportamento folclórico em extinção que deviam ser inventariados (OLIVEIRA, 2008, p. 60).

Mas foi no Estado Novo, com a presença de intelectuais nos órgãos governamentais, que foi estabelecido como objetivo nacional a construção da nova identidade brasileira, sem que, para isso, fosse preciso apelar para reprodução de outras culturas. O Serviço do Patrimônio Histórico e Artístico Nacional, o Sphan, foi implantado nessa época e sob essa mentalidade.

O primeiro órgão criado para preservação do patrimônio nacional foi a Inspetoria dos Monumentos Nacionais, em 1934, no Museu Histórico Nacional. O Instituto foi desativado e o órgão federal que assumiu esse papel foi o Sphan, em 1937. No momento de sua criação, o Sphan estava vinculado ao Ministério da Educação e gozava de autonomia, tanto da influência de interesses particulares ou do próprio governo, para atingir os objetivos instituídos para o órgão ${ }^{3}$.

Como afirma Oliveira (2008), na primeira fase de atuação do Sphan, na década de 1930, foram adotados como expressão da cultura e identidade brasileira as obras e imóveis

\footnotetext{
${ }^{3}$ O Decreto-lei $\mathrm{n}^{\circ} 25$, de 30/11/1937, cria a estrutura do Sphan e define seus objetivos.
} 
que remetiam ao barroco, o que seria, segundo os intelectuais do órgão, o primeiro estilo original brasileiro, a autêntica tradição brasileira. Esse marco foi então definido por eles, fazendo assim um "recorte" na história brasileira para definir o nascimento de nossa cultura. A gestão de Rodrigo Melo Franco de Andrade (1937-1967) privilegiou o patrimônio "pedra e cal", destacando a monumentalidade e privilegiando o aspecto estético dos bens imóveis. Mas entre as atividades do Sphan, nessa fase, ainda estavam as pesquisa, as viagens para catalogação e as restaurações de edificações.

Os intelectuais do Sphan teriam papel importante no processo de formação da identidade nacional, sendo atribuição de seu corpo técnico a definição de critérios de seleção dos bens culturais a serem tombados. Como se viu, nesse primeiro momento, o tombamento se voltou predominantemente para obras de arquitetura, justamente devido à composição do órgão, que era majoritariamente formado de arquitetos oriundos da Escola de Belas-Artes. Sendo os detentores dos critérios que resultariam no tombamento, a perspectiva estética predominou por décadas nesse processo, como forma de proteção daqueles bens. O Sphan, nesse sentido, buscava através de seus funcionários, resgatar o passado brasileiro para ajudar a construir a identidade nacional, através da política de tombamento. Assim, com a preservação de manifestações artísticas e arquitetônicas de valor excepcional era viável retomar a trajetória histórica e, a partir desse mecanismo, a origem da cultura brasileira, deixando o passado, como expressão nacional coletiva, estático e ao alcance de todos.

Além do mecanismo do tombamento, o Sphan tinha dentre suas atividades a pesquisa e restauração. A impressão que se passava era que o corpo técnico do órgão "atuava em nome dos interesses nacionais, acima dos interesses particulares ou do governo, e se considerava intérprete ou porta-voz da sociedade ainda desorganizada" (OLIVEIRA, 2008, p.121).

Mas não só do barroco se ocupava o Sphan. Os estilos neoclássico e moderno tiveram grande importância para a política de tombamento do país.

Os funcionários do órgão expressavam o pensamento modernista que se instalava no país. Este movimento possuiu em sua primeira fase a negação do passado estabelecendo uma nova estética para a construção de uma sociedade progressista. Sendo, que em seguida, o modernismo assumia a brasilidade, buscando encontrar o ser brasileiro.

Os intelectuais chamados modernistas procurariam mais tarde, através do folclore, mapear a identidade nacional, sendo ele assim considerado, por suas raízes de brasilidade, a representação da genuína tradição brasileira. Desse modo, era através do inventário das 
tradições e expressões culturais brasileiras que buscariam o reconhecimento da identidade nacional. No modernismo houve também uma releitura do Barroco, onde as festas e manifestações da religiosidade popular foram novamente valorizadas.

Como nos diz Oliveira (2008, p. 110):

\begin{abstract}
Os intelectuais, a partir do movimento modernista, pensaram sobre a arte, a história, a nação. Planejaram e executaram a modernização da sociedade e do Estado brasileiro. Formularam também a idéia de patrimônio e registraram os perigos a que essa herança estava sujeita. Desde então o patrimônio passou a ser questão oficial.
\end{abstract}

Mas a partir dos anos 1960, as políticas de tombamento foram consideradas inadequadas, pois se apresentavam de forma elitista, pouco representativas da diversidade cultural brasileira. Houve por parte dos intelectuais da época críticas às atividades do Iphan devido à falta de representatividade da pluralidade brasileira em suas ações para preservar o passado brasileiro.

Como observa Ortiz (2012), a política governamental pós-64, refletia uma nova forma do capitalismo, considerada, pelo autor, como uma nova revolução industrial no Brasil. O planejamento aplicado à área econômica, aos poucos, se expandiu para as outras esferas governamentais, incidindo na área cultural. Assim, desenvolveu-se um mercado de bens simbólicos que se destaca por seu volume e dimensão. As produções culturais, que antes atingiam um número reduzido de pessoas, passam a estar ao alcance de um público consumidor cada vez maior. E o mercado cultural adquiria uma dimensão nacional.

Nesse período, inicia-se uma política que visa a uma integração cultural a nível nacional. Assim, os órgãos que atuavam com ênfase na preservação do patrimônio passam a conviver com uma política diferenciada, com incentivo da produção cultural, dinamização dos circuitos de distribuição e o consumo de bens culturais. Dessa forma, não só os bens materiais sofrem a intervenção da lógica de mercado, mas ela estendeu-se aos bens imateriais da cultura nacional.

Foi nessa época, que, segundo Ortiz (2012), as principais instituições estatais são implementadas para que as diversas expressões culturais sejam organizadas e administradas, demonstrando a abrangência (de âmbito nacional), que se pretendia com essa política de Estado. Houve a intensificação da ação governamental nas políticas de apoio cultural, como, 
por exemplo, com a criação da Embrafilme e da Funarte, em uma tentativa de universalizar a cultura brasileira.

O reflexo na área de proteção patrimonial foi observado com a atuação de Aloísio Magalhães na formação do Centro Nacional de Referência Cultural (CNRC) e na direção da nova Secretaria do Patrimônio Histórico e Artístico Nacional e da Fundação Nacional PróMemória (1979). A consagração dos bens materiais já não era vista como suficiente para representar a identidade brasileira. Seria pela consagração do bem cultural que a identidade brasileira seria preservada das ameaças estrangeiras, mas a política praticada pelo Iphan até então não privilegiava as formas de expressão popular. Para Magalhães, o patrimônio não se restringia aos monumentos, mas abrangia da mesma forma o cotidiano brasileiro, reunindo diversas práticas e atentando para a relevância do patrimônio imaterial ou intangível, que compreendia lugares, festas, alimentos e saberes. Como ressalta Oliveira (2008, p. 135), a ideia de autenticidade e originalidade, que eram inerentes à condição do patrimônio, deram lugar à noção de referência cultural e continuidade histórica.

Mas foi na promulgação da Constituição Brasileira de 1988, que essa nova fase da política de patrimônio do Brasil é oficializada, pois a partir desse momento se tornava oficial com a necessidade de atentar para essa nova noção de patrimônio, dando o reconhecimento às expressões culturais diversas que fazem parte do patrimônio cultural brasileiro. Com essa ampliação de bens passíveis de reconhecimento, a expressão "patrimônio histórico e artístico" passou a ser substituída por "patrimônio cultural".

O costume de colecionar nasce da necessidade humana de construir a ideia de continuidade. O agrupamento de objetos e artefatos ultrapassou o seu estado físico, e passou a representar valores abstratos, como o resgate da memória, transformando seus significados. Com o passar do tempo, apenas os objetos não eram suficientes para se resguardar. Lugares, representados, predominantemente pelos monumentos, também eram palco de reverência, pois possibilitavam o ato de rememorar ritos e celebrações, além de servirem como uma referência simbólica de um passado comum.

Com o surgimento do patrimônio oficializado, difundiu-se o pensamento do legado coletivo. Os objetos, lugares, edificações seriam considerados testemunhas da história. Mas, ao mesmo tempo, surge também o questionamento quanto ao processo de seleção dos bens a serem preservados. Como observa Fonseca (2009), a preservação de um patrimônio cultural representa uma prática social, já que esse processo não implica apenas a esfera material desse 
bem, mas também seu aspecto simbólico, como referência de identidade, memória e história de uma sociedade.

O patrimônio cultural é reconhecido como um bem privilegiado, na medida em que, na nossa sociedade, ocupa um papel importante para a valorização cultural. Não esquecendo ainda da posição de destaque que o tombamento adquiriu no mercado turístico.

Observa-se que o tombamento foi um mecanismo utilizado para legitimar as identidades nacionais, porém discute-se se essa legitimidade, dada pelos órgãos oficiais, é suficiente para a representação de tais identidades.

No caso brasileiro, por um longo período, as políticas culturais tiveram como objetivo difundir e preservar as tradições culturais e os patrimônios paisagístico, histórico e artístico do país. Na década de 1930, houve o encontro do discurso governamental com a elite intelectual da época, na implantação do Sphan, sendo que os representantes do pensamento modernista foram convidados a compor o governo. O intuito dessa união era propor uma nova conceituação de políticas culturais.

Como afirma Oliveira (2008), no Sphan, seus colaboradores "passaram a reler o Brasil, sua cultura, como uma manifestação estética e histórica da coletividade brasileira" (OLVIEIRA, 2008, p. 123). Os bens inventariados pelo órgão deveriam, assim, representar a nação brasileira na sua diversidade.

Porém, como afirma a autora, mesmo que fosse realizado, por parte dos órgãos gestores, um grande esforço para a construção de uma ideia de nação coesa, representada acima das diversidades culturais encontradas no Brasil, a imagem que foi construída pelo Estado, por mais de sessenta anos "está longe de refletir a diversidade, assim como as tensões e os conflitos que caracterizaram a produção cultural do Brasil, sobretudo a atual, mas também a do passado" (FONSECA, 2008, p. 59).

Procurando reverter essa distorção, no Brasil dos anos 1960 houve a busca, por parte dos intelectuais, da verdadeira e autêntica identidade nacional. Com a instalação da indústria cultural e com os programas governamentais para preservação e difusão dos bens culturais em âmbito nacional, o volume de obras e expressões culturais era muito mais diversificado e atingia um número muito maior de pessoas do que nas décadas anteriores.

Mesmo com esse empenho, a memória oficial, por vezes, não é coincidente com as expressões culturais brasileiras e ao se apresentar desprovida de identificação, revela as relações de desigualdade presentes em cada localidade. Como nos diz Ortiz, a ausência das 
pessoas comuns nos debates que tratam da questão da preservação demonstra o descompasso das superestruturas de políticas culturais em relação à realidade global da sociedade brasileira (ORTIZ, 2012).

Não foi só o Iphan que puxou para si a tentativa de construção da identidade brasileira através do tombamento. Órgãos estaduais e distritais replicaram esse comportamento.

No caso de Brasília, está a cargo da Secretaria de Cultura do Distrito Federal a oficialização do patrimônio cultural. Como veremos a seguir, além do Conjunto Urbanístico de Brasília, no Distrito Federal existem ainda 30 bens que receberam o título de Patrimônio Cultural do Distrito Federal, como também outros 34 bens considerados Patrimônio Cultural do Brasil. Nesse sentido, esta pesquisa se coloca como forma de compreender como se deu essa constituição, procurando analisar as nuances desse processo, além de buscar compreender em que medida a gestão desse patrimônio atua na promoção da cidade como um destino turístico. 


\section{CAPÍTULO 2 - O PATRIMÔNIO CULTURAL DE BRASÍLIA: SUA CONSTITUIÇÃO}

Até este momento do presente trabalho, apresentamos um breve panorama da história do patrimônio, como se dá sua constituição oficial e sua relação com a identidade nacional. A partir de então, apresentaremos a constituição do patrimônio cultural no Distrito Federal, para examinar a importância da atuação do poder público na valorização do patrimônio cultural local e a possibilidade de promoção e incentivo ao turismo local.

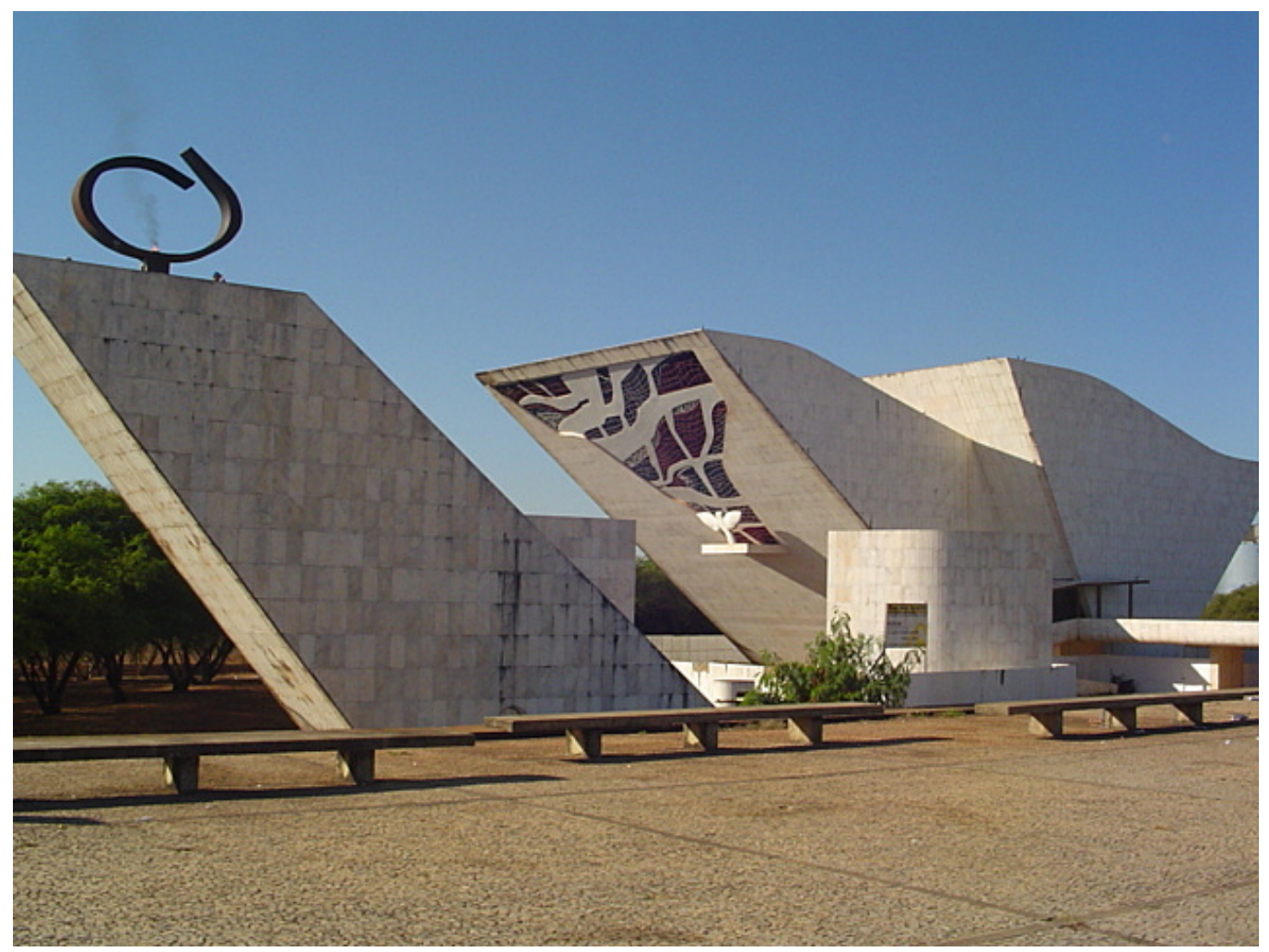

Figura 1 - Panteão da Pátria e da Liberdade Tancredo Neves Fonte: Internet ${ }^{4}$

\footnotetext{
${ }^{4}$ Foto extraída de:

https://pt.wikipedia.org/wiki/Pante\%C3\%A3o_da_P\%C3\%A1tria_e_da_Liberdade_Tancredo_Neves. Acesso em 06/02/2015.
} 
Brasília nasceu sob o ideal estético brasileiro, racionalmente planejada e integrando as artes visuais na arquitetura e na natureza. O "museu a céu aberto" desperta não só nos visitantes, como também em seus moradores, a consciência do privilégio e também do ônus que essa condição acarreta. O privilégio deriva do prestígio adquirido pela cidade ao abrigar mais de 60 bens tombados, além do título de Patrimônio Cultural da Humanidade, para seu conjunto urbanístico. Em contrapartida, o ônus advém da responsabilidade atribuída aos órgãos governamentais para a preservação desse patrimônio.

Até o ano de 2014, havia no Distrito Federal 61 bens tombados, sendo que 34 pelo Iphan e 31 pelo governo local, ressaltando que 4 deles (o Catetinho, o Conjunto Urbanístico de Brasília, a Igrejinha e a Pedra Fundamental) constam na lista dos órgãos das duas esferas. Os bens tombados em nível federal são predominantemente constituídos de edificações representativas da arquitetura moderna que se tornaram característica na capital, sendo que em sua maioria representam monumentos e obras do arquiteto Oscar Niemeyer (Tabela 1).

A lista oficial do Iphan de bens tombados no Distrito Federal revela que apenas 3 deles estão inscritos em livros de tombo, a saber: o Catetinho (1959), a Catedral Metropolitana (1962) e a Placa de ouro oferecida a Rui Barbosa pelo Senado por sua participação no Congresso de Haya em 1907 (1985). Os outros bens, ainda estão com o processo para o tombamento em fase de instrução, sem ter havido a efetivação de suas inscrições. Porém, mesmo assim eles já são considerados patrimônio pela comunidade local e poder público, devido ao seu significativo valor simbólico.

Tabela 1 - Bens Tombados pelo Iphan no Distrito Federal

\begin{tabular}{|l|c|c|c|}
\hline \multicolumn{3}{|c|}{ BENS TOMBADOS PELO IPHAN NO DISTRITO FEDERAL } \\
\hline NOME DO BEM / LOCALIZAÇÃo & $\begin{array}{c}\text { ANO DE ABERTURA DO } \\
\text { PROCESSO }\end{array}$ & SITUAÇÃo & CLASSIFICAÇÃO \\
\hline $\begin{array}{l}\text { 1. Catetinho } \\
\text { (Gama) }\end{array}$ & 1959 & Tombado & Edificação \\
\hline $\begin{array}{l}\text { 2. Catedral Metropolitana } \\
\text { (Brasília / Plano Piloto) }\end{array}$ & 1962 & Tombado & Edificação \\
\hline $\begin{array}{l}\text { 3. Hospital Juscelino Kubitschek } \\
\text { (Núcleo Bandeirante) }\end{array}$ & 1983 & $\begin{array}{c}\text { Tombamento } \\
\text { provisório }\end{array}$ & Edificação \\
\hline $\begin{array}{l}\text { 4. Placa de ouro oferecida a Rui } \\
\text { Barbosa pelo Senado por sua } \\
\text { participação no Congresso de Haya } \\
\text { em 1907 }\end{array}$ & 1985 & Tombado & $\begin{array}{c}\text { Bens móveis e } \\
\text { integrados }\end{array}$ \\
\hline $\begin{array}{l}\text { 5. Conjunto urbanístico de Brasília } \\
\text { construído em decorrência do Plano }\end{array}$ & 1990 & Rerratificado & Conjunto urbano \\
\hline
\end{tabular}

${ }^{5}$ O processo de tombamento do Conjunto Urbanístico de Brasília está na Superintendência do Iphan no Distrito Federal para realização de estudos que visam a rerratificação da poligonal de tombamento. 


\begin{tabular}{|c|c|c|c|}
\hline $\begin{array}{l}\text { Piloto traçado para a cidade } \\
\text { (Brasília / Plano Piloto) }\end{array}$ & & & \\
\hline $\begin{array}{l}\text { 6. Antiga sede da Fazenda Gama, } \\
\text { Setor de Áreas Isoladas Sul, ao lado } \\
\text { do PHN Catetinho - ParkWay } \\
\text { (Gama) }\end{array}$ & 2005 & Instrução & Edificação \\
\hline $\begin{array}{l}\text { 7. Mesa da funcionária da sede do } \\
\text { Conselho Federal da OAB, Lydia } \\
\text { Monteiro da Silva - Museu da OAB, } \\
\text { SAS Quadra 05 Bloco N, Lote 02 } \\
\text { (Brasília / Plano Piloto) }\end{array}$ & 2006 & Instrução & $\begin{array}{l}\text { Bens móveis e } \\
\text { integrados }\end{array}$ \\
\hline $\begin{array}{l}\text { 8. Teatro Nacional } \\
\text { (Brasília / Plano Piloto) }\end{array}$ & 2007 & Instrução & Edificação \\
\hline $\begin{array}{l}\text { 9. Capela Nossa Senhora de Fátima - } \\
\text { Igrejinha } \\
\text { (Brasília / Plano Piloto) }\end{array}$ & 2007 & Instrução & Edificação e acervo \\
\hline $\begin{array}{l}\text { 10. Casa de chá } \\
\text { (Brasília / Plano Piloto) }\end{array}$ & 2007 & Instrução & Edificação \\
\hline $\begin{array}{l}\text { 11. Congresso Nacional } \\
\text { (Brasília / Plano Piloto) }\end{array}$ & 2007 & Instrução & Edificação \\
\hline $\begin{array}{l}\text { 12. Conjunto Cultural da República } \\
\text { (Brasília / Plano Piloto) }\end{array}$ & 2007 & Instrução & Edificação \\
\hline $\begin{array}{l}\text { 13. Conjunto Cultural Funarte } \\
\text { (Brasília / Plano Piloto) }\end{array}$ & 2007 & Instrução & Edificação \\
\hline $\begin{array}{l}\text { 14. Edifício Touring Club do Brasília } \\
\text { (Brasília / Plano Piloto) }\end{array}$ & 2007 & Instrução & Edificação \\
\hline $\begin{array}{l}\text { 15. Espaço Lucio Costa } \\
\text { (Brasília / Plano Piloto) }\end{array}$ & 2007 & Instrução & Edificação \\
\hline $\begin{array}{l}\text { 16. Espaço Oscar Niemeyer } \\
\text { (Brasília / Plano Piloto) }\end{array}$ & 2007 & Instrução & Edificação \\
\hline $\begin{array}{l}\text { 17. Memorial dos Povos Indígenas } \\
\text { (Brasília / Plano Piloto) }\end{array}$ & 2007 & Instrução & Edificação \\
\hline $\begin{array}{l}\text { 18. Memorial JK } \\
\text { (Brasília / Plano Piloto) }\end{array}$ & 2007 & Instrução & Edificação \\
\hline $\begin{array}{l}\text { 19. Conjunto dos Ministérios e } \\
\text { Anexos } \\
\text { (Brasília / Plano Piloto) }\end{array}$ & 2007 & Instrução & Edificação \\
\hline $\begin{array}{l}\text { 20. Museu da Cidade } \\
\text { (Brasília / Plano Piloto) }\end{array}$ & 2007 & Instrução & Edificação \\
\hline $\begin{array}{l}\text { 21. Conjunto do Palácio da Alvorada } \\
\text { - incluindo capela } \\
\text { (Brasília / Plano Piloto) }\end{array}$ & 2007 & Instrução & Conjunto arquitetônico \\
\hline $\begin{array}{l}\text { 22. Palácio da Justiça } \\
\text { (Brasília / Plano Piloto) }\end{array}$ & 2007 & Instrução & Edificação \\
\hline $\begin{array}{l}\text { 23. Palácio do Planalto } \\
\text { (Brasília / Plano Piloto) }\end{array}$ & 2007 & Instrução & Edificação \\
\hline $\begin{array}{l}\text { 24. Palácio Itamaraty e anexos } \\
\text { (Brasília / Plano Piloto) }\end{array}$ & 2007 & Instrução & Edificação \\
\hline $\begin{array}{l}\text { 25. Palácio Jaburu } \\
\text { (Brasília / Plano Piloto) }\end{array}$ & 2007 & Instrução & Edificação \\
\hline $\begin{array}{l}\text { 26. Panteão da Liberdade e } \\
\text { Democracia } \\
\text { (Brasília / Plano Piloto) }\end{array}$ & 2007 & Instrução & Edificação \\
\hline $\begin{array}{l}\text { 27. Pombal } \\
\text { (Brasília / Plano Piloto) }\end{array}$ & 2007 & Instrução & Edificação \\
\hline $\begin{array}{l}\text { 28. Praça dos Três Poderes } \\
\text { (Brasília / Plano Piloto) }\end{array}$ & 2007 & Instrução & Edificação \\
\hline 29. Quartel General do Exército & 2007 & Instrução & Edificação \\
\hline
\end{tabular}




\begin{tabular}{|c|c|c|c|}
\hline (Brasília / Plano Piloto) & & & \\
\hline $\begin{array}{l}\text { 30. Supremo Tribunal Federal } \\
\text { (Brasília / Plano Piloto) }\end{array}$ & 2007 & Instrução & Edificação \\
\hline $\begin{array}{l}\text { 31. Edifício denominado } \\
\text { "Beijódromo", sede da Fundação } \\
\text { Darcy Ribeiro, na UnB } \\
\text { (Brasília / Plano Piloto) }\end{array}$ & 2014 & Instrução & Edificação \\
\hline $\begin{array}{l}\text { 32. Conjunto Arquitetônico, } \\
\text { Urbanístico e Paisagístico de } \\
\text { Planaltina } \\
\text { (Planaltina) }\end{array}$ & 1964 & Instrução & Conjunto urbano \\
\hline $\begin{array}{l}\text { 33. Igreja de São Sebastião } \\
\text { (Planaltina) }\end{array}$ & 2002 & Instrução & Edificação e acervo \\
\hline $\begin{array}{l}\text { 34. Pedra Fundamental } \\
\text { (Planaltina) }\end{array}$ & Não informado & Instrução & $\begin{array}{l}\text { Bens móveis e } \\
\text { integrados }\end{array}$ \\
\hline
\end{tabular}

O processo de tombamento do Iphan na capital segue sua lógica histórica, quando observamos que dentre os 34 bens, 30 são classificados como edificações. O fato de serem representantes da arquitetura moderna, também é coerente com a política do órgão, pois a ideologia empregada para a construção de Brasília desprezou as populações existentes aqui antes da inauguração, sendo anunciada como uma cidade criada ex nihilo ${ }^{6}$.

A leitura do Iphan, ao privilegiar os padrões estéticos modernistas após a década de 1960, expressa a valorização dessa manifestação como representante da originalidade da cultura brasileira. As edificações ainda são majoritárias na lista do Órgão. E no caso de Brasília, elas estão simbolizadas essencialmente pelas obras de Oscar Niemeyer.

Notamos que foi a partir de 2007 que, para a maioria dos bens, começa o processo de tombamento pelo Órgão e que a disposição deles está no centro administrativo da capital, coincidente com seu conjunto urbanístico. Infere-se que após a inclusão de Brasília na Lista de Patrimônio Mundial, houve a preocupação em preservar as edificações instaladas na área tombada a fim de conservar o perfil arquitetônico e urbanístico que deram motivo ao título.

\subsection{Patrimônio Cultural do Distrito Federal - GDF}

\subsubsection{A Secretaria de Cultura do Distrito Federal - Um breve histórico}

Duarte (2011) refere-se ao Plano Educacional de Brasília, elaborado em 1956, como a primeira proposta para a área de educação e cultura no Distrito Federal, sendo o Departamento de Educação e Difusão Cultural da Companhia Urbanizadora da Nova Capital

\footnotetext{
${ }^{6}$ Expressão latina que significa "do nada".
} 
do Brasil - Novacap, dirigida à época por Ernesto Silva, o responsável pela aplicação do plano.

A gênese de uma estrutura administrativa para cuidar da cultura local começa com a Fundação Cultural, parte integrante da Secretaria de Educação e Cultura do Distrito Federal SEC/GDF, fundada em 17 de junho de 1960, e que teve como seu primeiro diretor o poeta Ferreira Gullar. À Fundação era delegado o dever de refletir a diversidade cultural brasileira, além da função de estímulo à atividade cultural local. Como relata a autora

O projeto cultural para a cidade deveria considerar uma realidade específica: Brasília era a junção do mais antigo - a cultura trazida pela mão de obra operária- com o mais novo do Brasil - o urbanismo de Lucio Costa e a arquitetura de Niemeyer (DUARTE, 2011, p. 63).

Assim, sendo Brasília o símbolo do país moderno e desenvolvimentista e para corresponder a esse pensamento da cultura síntese da fusão das expressões culturais brasileiras, a Fundação Cultural deveria, como missão inicial, atuar na promoção do que havia de mais moderno nos diversos campos da cultura e também estimular as atividades de arte popular no âmbito local.

Em 1976, foi criado na Secretaria de Educação e Cultura, o Departamento de Cultura, órgão normativo para a área cultural, que possuía também entre seus objetivos a "pesquisa e análise do complexo cultural do DF" (DUARTE, 2011, p. 116). Era vinculado a esse Departamento que funcionava a Divisão de Patrimônio Histórico e Artístico do Distrito Federal, à qual era atribuído o levantamento das edificações de valor histórico e artístico para posteriormente proceder com o tombamento.

Em 1999, a Fundação Cultural foi extinta pelo Decreto no 20.264 e suas atribuições foram transferidas para a recém-criada Secretaria de Cultura do Distrito Federal. A partir de então, ficou a cargo do Departamento de Patrimônio Histórico e Artístico do DF - Depha o acompanhamento e a preservação do patrimônio cultural do Distrito Federal. Em 2011, depois de nova reestruturação administrativa, a designação do Depha passou a ser Subsecretaria do Patrimônio Histórico, Artístico e Cultural - Suphac.

Vimos que desde a criação dos órgãos para a gestão e proteção do patrimônio cultural do Distrito Federal houve a preocupação em inventariar e preservar os bens que o compõem. As mudanças administrativas na Secretaria de Cultura, durante esse tempo, não trouxeram inovações nas ações governamentais nesse sentido. Observamos a restauração de algumas 
edificações que tiveram sua interdição determinada por impossibilidade de uso, mas não percebemos do poder público que pudessem apontar para um incremento do turismo local após tais intervenções. A gestão da Secretaria de Cultura incide diretamente em apenas 9 dos 61 bens tombados no Distrito Federal. As mudanças administrativas demonstram a intenção governamental em regulamentar as atividades incidentes na preservação e revitalização do patrimônio cultural local. Porém, observamos que pela falta de articulação com outros organismos para a implementação de programas, o turismo ocorre ainda de forma espontânea nesses equipamentos culturais, sem uma efetiva sistematização do desenvolvimento turístico por parte da administração pública.

No Distrito Federal, para que ocorra o tombamento, a solicitação é encaminhada ao Secretário de Estado de Cultura, com a justificativa para a proposta e dados do bem, como localização, dados históricos, fotografias e outras informações relevantes para o início da instrução do processo. É na Suphac que é iniciado o procedimento formal que concede ou recusa a chancela de Patrimônio Cultural do Distrito Federal.

A exemplo de como ocorre no Iphan, o processo para aquisição do título necessita de parecer do seu corpo técnico para legitimar o valor singular do bem. Se aprovado e cumpridas essas etapas, após a assinatura de decreto específico pelo Governador do Distrito Federal, o bem passa a constar nos livros de tombo.

No âmbito distrital, essa atuação é regulamentada basicamente pelos vários documentos distintos, que são a Lei Orgânica do Distrito Federal, o Decreto n 10.829/1987, a Lei $n^{\circ} 47 / 1989$, a Lei $n^{\circ} 3.977 / 2007$ e o Decreto $n^{\circ} 28.520 / 2007^{7}$.

\subsection{A dinâmica do tombamento no $D F$}

\subsubsection{LODF}

A mais elevada regulamentação da instância distrital, a Lei Orgânica do Distrito Federal (LODF), definiu, em vários artigos, a responsabilidade que o Governo do Distrito Federal tem diante de seu patrimônio (cultural, histórico e artístico) e da condição de Brasília, como Patrimônio Cultural da Humanidade. A LODF estabeleceu, na área de turismo, meio

\footnotetext{
${ }^{7}$ No documento "Brasília Revisitada" (ANEXO II), de 1987, elaborado por Lúcio Costa, estão listadas as características originais do Plano Piloto a serem preservadas e que, de uma maneira geral, formaram a base para a legislação de tombamento.
} 
ambiente e política urbana que a preservação, a manutenção e segurança deste patrimônio serão princípios norteadores da Política de Desenvolvimento Urbano.

A Lei traz em seu artigo $3^{\circ}$, inciso $X$, como objetivo prioritário do Distrito Federal o zelo pelo conjunto urbanístico de Brasília, tombado sob a inscrição $\mathrm{n}^{\circ} 532$ do Livro do Tombo Histórico, sendo que devem ser respeitadas as definições e critérios do Iphan para que não haja disparidade quanto à salvaguarda e gestão dos bens culturais.

O documento também dedica a Seção II, de seu Capítulo IV, à cultura, inclusive à proteção do patrimônio artístico, histórico e cultural locais.

A LODF apresenta ainda algumas diretrizes para o caso de danos e ameaças ao patrimônio cultural, indicando, mesmo de forma genérica, punições, subordinadas à legislação específica. Observa-se no artigo $\mathrm{n}^{\circ} 248$, que visando estimular o desenvolvimento cultural, o poder público estimula, por meio de incentivos fiscais, a empreendimentos privados que se voltem para a produção cultural e artística, como também para a preservação e restauração do patrimônio cultural do Distrito Federal. Já no art. 360, há referência ao Conselho de Defesa do Patrimônio Cultural do Distrito Federal, responsável por estabelecer a política que assegure a preservação do patrimônio cultural ${ }^{8}$.

\subsubsection{Decreto $n^{\circ} 10.829$, de 14 de outubro de 1987}

Este decreto determina o perímetro de preservação e define que a concepção urbanística de Brasília deve ser mantida atendendo as quatro escalas que caracterizam o projeto urbanístico de Lucio Costa: a monumental, a residencial, a gregária e a bucólica ${ }^{9}$. É esse decreto que regulamenta o art. 38 da Lei $n^{\circ} 3.751^{10}$, de 13 de abril de 1960, que dispõe que "qualquer alteração no plano-piloto, a que obedece a urbanização de Brasília, depende de autorização em lei federal".

\footnotetext{
${ }^{8}$ O Conselho de Defesa do Patrimônio Cultural do Distrito Federal é um colegiado, subordinado à Subsecretaria do Patrimônio Histórico, Artístico e Cultural (Suphac), estrutura da Secretaria de Cultura do DF. É competência do Conselho deliberar sobre questões de tombamento, registro e preservação dos bens culturais, artísticos e históricos do Distrito Federal.

${ }^{9}$ Os princípios de urbanismo moderno forma definidos pela Carta de Atenas, elaborada por Le Corbusier, onde a cidade deveria apresentar quatro funções básicas: habitação, circulação, trabalho e diversão. Lucio Costa se serve deles para a construção do plano urbanístico de Brasília.

${ }^{10}$ Lei Santiago Dantas.
} 
Até então a legislação referente ao patrimônio do Distrito Federal, restringia-se ao Conjunto Urbanístico da capital, mas é a partir da Lei $\mathrm{n}^{\circ} 47$ que surge a previsão da regulamentação dos bens considerados de valor cultural do Distrito Federal. A Lei estabelece os critérios para o tombamento, a competência do Conselho de Defesa do Patrimônio Cultural, como também prevê o cancelamento do tombamento, mas a legislação só reportar-se aos bens materiais ${ }^{11}$.

Essa lei é regulamentada pelo Decreto $\mathrm{n}^{\circ} 25.849$, de 17 de maio de 2005, que dispõe sobre o tombamento de bens de valor cultural, pelo Governo do Distrito Federal. A lei define o patrimônio artístico, histórico e natural e define os critérios para sua avaliação. Além disso, elenca os livros de tombo necessários na Suphac (o antigo Depha).

Quanto à preservação dos bens tombados, a Lei dispõe que os atos cometidos contra esse patrimônio serão equiparados aos cometidos contra o patrimônio nacional. Essa legislação enfatiza a importância de conservar e proteger os bens tombados, mas não atribui a nenhum órgão específico tal papel.

\subsection{A formação do Patrimônio Cultural do Distrito Federal}

Até o fim do ano de 2014, o Governo do Distrito Federal tinha inventariados 31 bens tombados e, como vimos, alguns deles possuem também o título de Patrimônio Cultural do Brasil.

${ }^{11}$ A legislação afeta ao registro de bens imateriais só surge em 2007, com a publicação da Lei $n^{\circ} 3.977$ e do Decreto $\mathrm{n}^{\mathrm{o}}$ 28.520, que dispõem sobre o registro de bens de natureza imaterial que constituem o Patrimônio Cultural do Distrito Federal. 


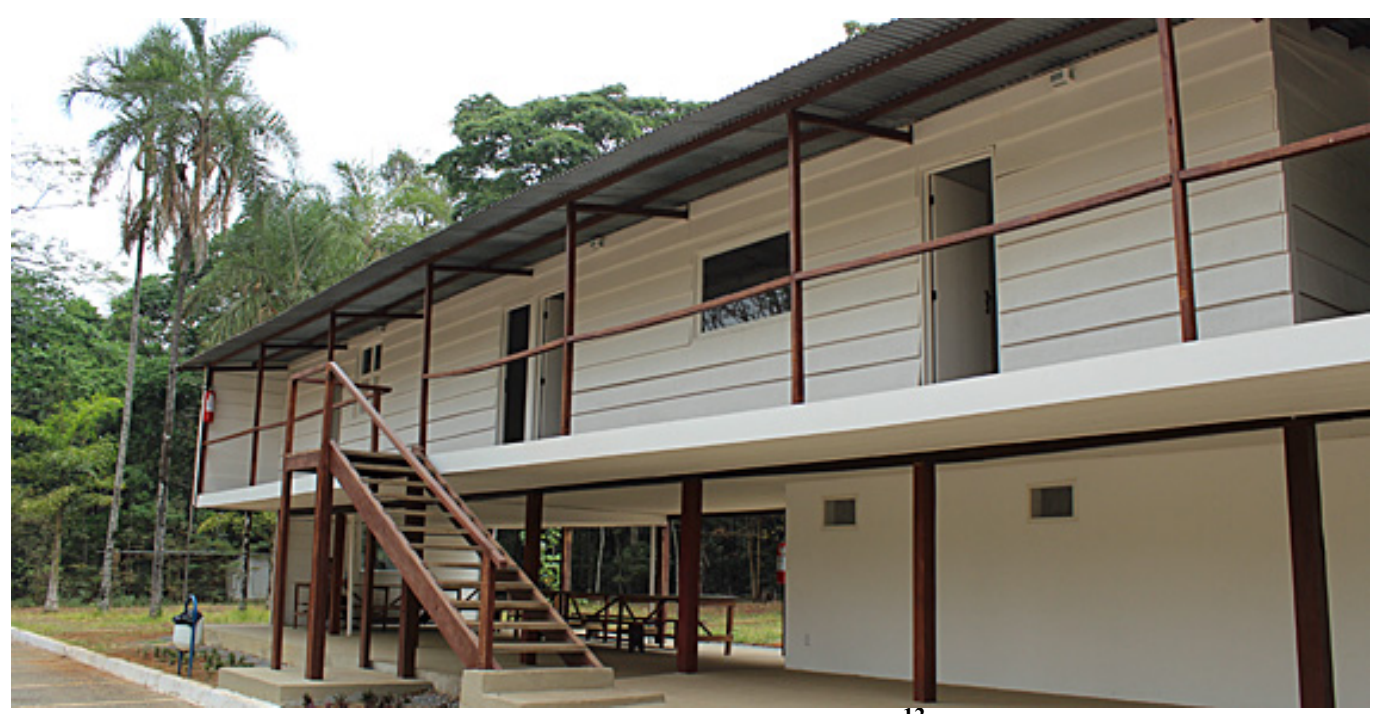

Figura 2 - Museu do Catetinho ${ }^{12}$ Fonte: Internet ${ }^{13}$

Observamos que o processo de tombamento das edificações ocorre desde antes da inauguração da capital, quando, em 1959, o Museu do Catetinho, que abrigou o presidente Juscelino Kubitscheck na época da construção de Brasília, já havia recebido o título pelo Iphan.

O processo das ações de tombamento, em nível distrital, começa a partir de 1982, com o tombamento da Igreja Nossa Senhora de Fátima, a Igrejinha.

\footnotetext{
${ }^{12}$ Projetado por Oscar Niemayer, o Catetinho foi erguido em apenas dez dias. O prédio foi construído abrigar o presidente Juscelino Kubitschek e sua comitiva durante a construção da capital. O nome Catetinho é uma referência ao Palácio do Catete, sede do Governo Federal até então, no Rio de Janeiro. Por sua construção ser toda em madeira, o Catetinho foi apelidado de Palácio de Tábuas. Atualmente, o Catetinho é um museu aberto à visitação pública e sob a custódia da Secretaria de Cultura do Distrito Federal.

${ }^{13}$ Foto extraída de http://www.viajenaviagem.com/2012/09/vnvbrasil-intrigas-palacianas-alvorada-X-catetinho.
} 


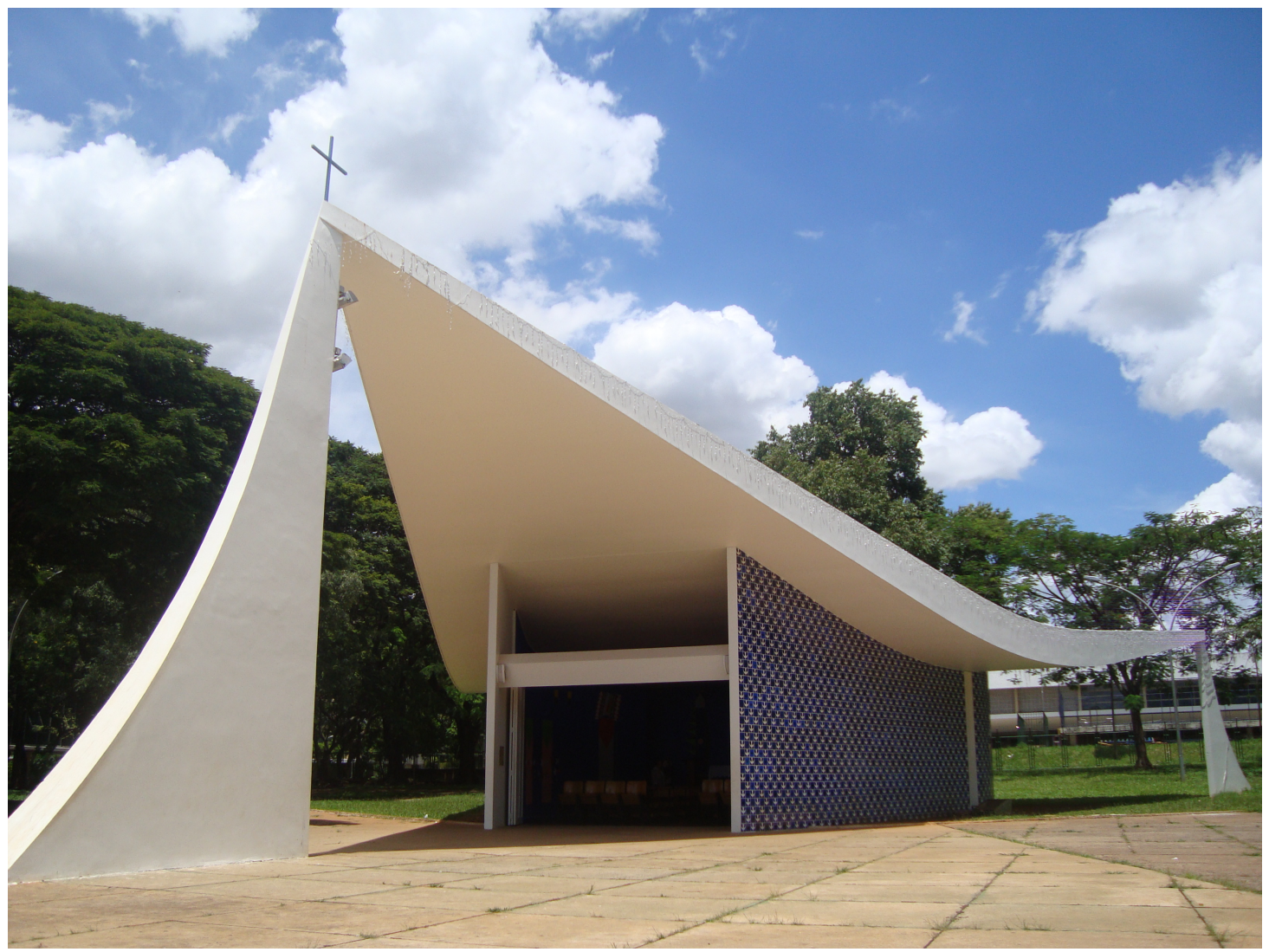

Figura 3 - Igreja Nossa Senhora de Fátima ${ }^{14}$ Autor: Daniel Souza Lima / Fonte: Internet ${ }^{15}$

Na década de 1980, foram transformadas em patrimônio cultural 13 edificações (à exceção da Árvore do Buriti), consideradas de significativo valor histórico e cultural para o Distrito Federal. Porém, na década seguinte, apenas 5 bens foram tombados, sendo o processo para a construção do patrimônio atual foi retomado em 2004. Desse ano até 2014, mais 13 bens entraram para a lista de tombo.

${ }^{14}$ A Igrejinha foi inaugurada em 1958, pelo presidente Juscelino Kubistchek, em razão de uma promessa. Foi projetada por Oscar Niemeyer e tinha em seu interior obras do artista Volpi. Em 2009, o Iphan autorizou a reforma e houve bastante polêmica, pois o interior, ao invés de ser restaurado, abrigaria obras do artista plástico Francisco Galeno.

${ }^{15}$ Foto extraída de https://geolocation.ws/v/P/31310670/igrejinha-de-nossa-senhora-de-ftima/en. Acesso em 06/02/2015. 


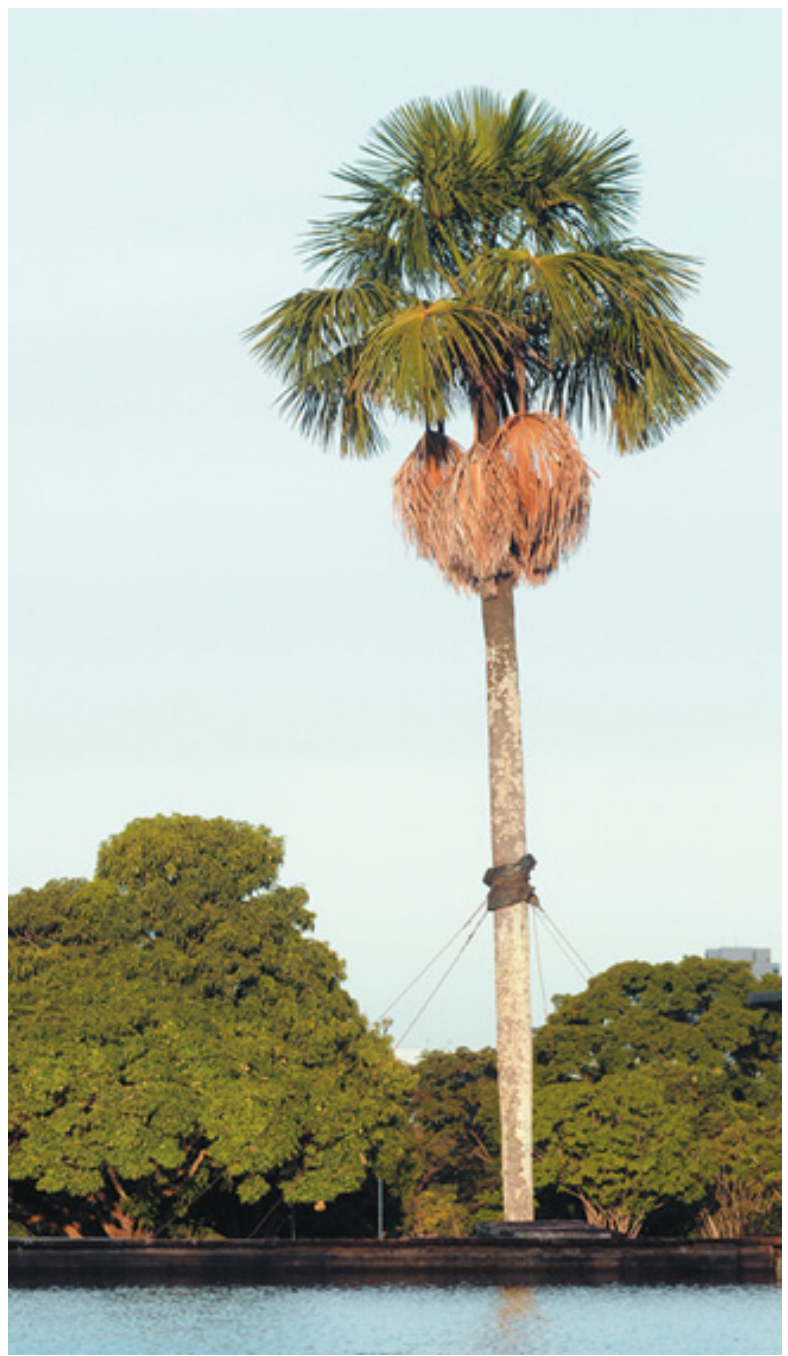

Figura 4 - Árvore do Buriti ${ }^{16}$ Fonte: Internet ${ }^{17}$

A Tabela 2 traz o patrimônio cultural constituído no Distrito Federal até o momento.

${ }^{16}$ A Árvore do Buriti é a palmeira que dá nome ao palácio do Poder Executivo distrital. Em 1959, Israel Pinheiro, que à época ocupava a presidência da Novacap, ordenou que fosse plantado o exemplar no local onde seria construído a sede do Governo. A inspiração veio do poema Um buriti perdido, do livro "Pelo Sertão", de Afonso Arinos de Melo Franco. Porém, a árvore morreu, restando apenas a placa com trechos da poesia gravados. Plantaram um novo buriti em 1969 e, no ano seguinte, construíram a praça ao redor dele. O tombamento pelo GDF ocorreu em 1985.

${ }^{17}$ Foto extraída de

http://sites.correioweb.com.br/app/noticia/encontro/encontroindica/2014/08/19/interna_encontro_indica,1398/ins cricoes-abertas-para-premio-ambiental-hugo-werneck.shtml. Acesso em 06/02/2015. 
Tabela 2 - Patrimônio Cultural do Distrito Federal

\begin{tabular}{|c|c|c|c|}
\hline \multicolumn{4}{|c|}{ PATRIMÔNIO CULTURAL DO DISTRITO FEDERAL ${ }^{18}$} \\
\hline NOME DO BEM & $\begin{array}{c}\text { ANO DO } \\
\text { TOMBAMENTO }\end{array}$ & LOCALIZAÇÃO & INSTRUMENTO DE TOMBAMETNO \\
\hline $\begin{array}{l}\text { 1. Igreja Nossa Senhora de } \\
\text { Fátima - Igrejinha }\end{array}$ & 1982 & Brasília / Plano Piloto & Decreto $\mathrm{n}^{\circ} 6.717$, de $28 / 04 / 1982$ \\
\hline 2. Museu da Cidade & 1982 & Brasília / Plano Piloto & Decreto $^{\circ} 6.718$, de $28 / 04 / 1982$ \\
\hline $\begin{array}{l}\text { 3. Museu Histórico e } \\
\text { Artístico de Planaltina }\end{array}$ & 1982 & Planaltina & Decreto $\mathrm{n}^{\circ} 6.939$, de 19/08/1982 \\
\hline 4. Igreja São Sebastião & 1982 & Planaltina & 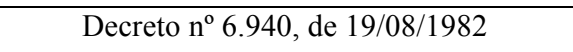 \\
\hline 5. Pedra Fundamental & 1982 & Planaltina & Decreto $^{0} 7.010$, de $7 / 09 / 1982$ \\
\hline 6. Árvore do Buriti & 1985 & Brasília / Plano Piloto & 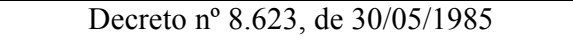 \\
\hline $\begin{array}{l}\text { 7. Hospital Juscelino } \\
\text { Kubitschek de Oliveira - } \\
\text { HJKO }\end{array}$ & 1985 & Núcleo Bandeirante & Decreto $\mathrm{n}^{\circ} 9.036$, de 13/11/1985 \\
\hline 8. Memorial JK & 1986 & Brasília / Plano Piloto & Decreto $^{\circ}$ 9.411, de 20/04/1986 \\
\hline $\begin{array}{l}\text { 9. Conjunto Urbanístico do } \\
\text { Plano Piloto }\end{array}$ & 1987 & Brasília / Plano Piloto & $\begin{array}{l}\text { GDF: Decreto } \mathrm{n}^{\circ} 10.829, \text { de } 14 / 10 / 87, \\
\text { publicado no DODF de 23/10/87, que } \\
\text { regulamenta o artigo } \mathrm{n}^{\circ} 38 \text { da Lei } \mathrm{n}^{\circ} 3.751 \text {, } \\
\text { de 13/4/60 (Lei Santiago Dantas), alterado } \\
\text { pelo Decreto } \mathrm{n}^{\circ} 12.254 \text {, de } 7 / 3 / 90 \text {, publicado } \\
\text { DODF de } 8 / 3 / 90\end{array}$ \\
\hline 10. Ermida Dom Bosco & 1988 & Brasília / Lago Sul & Decreto $\mathrm{n}^{\circ} 11.032$, de $2 / 03 / 1988$ \\
\hline 11. Vila Planalto & 1988 & Vila Planalto & 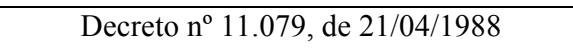 \\
\hline 12. Escola Classe 308 Sul & 1988 & Brasília / Plano Piloto & 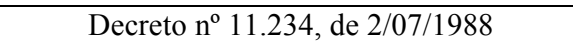 \\
\hline 13. Relógio de Taguatinga & 1989 & Taguatinga & Decreto $^{\circ} 11.823$, de $18 / 09 / 1989$ \\
\hline 14. Museu do Catetinho & 1991 & Gama & Depha/GDF - 19/11/1991 \\
\hline $\begin{array}{l}\text { 15. Catedral Metropolitana } \\
\text { de Brasília }\end{array}$ & 1991 & Brasília / Plano Piloto & Depha/GDF - 19/11/1991 \\
\hline 16. Igreja São Geraldo & 1993 & Paranoá & Decreto $^{\circ} 15.156$, de 27/10/1993 \\
\hline
\end{tabular}

${ }^{18}$ Apenas em 2004, foi registrado o primeiro bem imaterial do Distrito Federal. Até 2014, se computava 7 bens como Patrimônio Imaterial do Distrito Federal: Bumba Meu Boi Seu Teodoro (2004), Festival de Brasília do Cinema Brasileiro (2007), Ideário Pedagógico de Anísio Teixeira (2007), Clube do Choro de Brasília (2008), Via Sacra ao Vivo de Planaltina (2008), Associação Recreativa Cultural Unidos do Cruzeiro - ARUC (2009) e Festa do Divino Espírito Santo de Planaltina (2013). 


\begin{tabular}{|c|c|c|c|}
\hline $\begin{array}{l}\text { 17. Centro de Ensino } \\
\text { Metropolitana }\end{array}$ & 1995 & Núcleo Bandeirante & Decreto $\mathrm{n}^{\circ} 16.744$, de $12 / 09 / 1995$ \\
\hline 18. Igreja São José Operário & 1998 & Candangolândia & Decreto $^{\circ}{ }^{\circ} 19.960$, de 29/12/1998 \\
\hline 19. Escola Parque 308 Sul & 2004 & Brasília / Plano Piloto & Decreto $\mathrm{n}^{\circ} 24.861$, de $4 / 08 / 2004$ \\
\hline 20. Casa da Fazenda Gama & 2006 & Gama & Decreto $^{\circ} 26.660$, de 21/03/2006 \\
\hline 21. Cine Brasília & 2007 & Brasília / Plano Piloto & Decreto $^{\circ} 28.519$, de 7/12/2007 \\
\hline $\begin{array}{l}\text { 22. Teatro Dulcina de } \\
\text { Moraes e Acervos } \\
\text { Fotográfico, Textual e } \\
\text { Cênico da atriz }\end{array}$ & 2007 & Brasília / Plano Piloto & Decreto $^{\circ} 28.518$, de $7 / 12 / 2007$ \\
\hline 23. Revista Brasília* & 2008 & Guará & Decreto $^{\circ} 28.996$, de 29/04/2008 \\
\hline 24. Clube de Golfe & 2009 & Brasília / Plano Piloto & Decreto $^{\circ}$ 30.839, de 25/09/2009 \\
\hline $\begin{array}{l}\text { 25. Acervo da Obra Musical } \\
\text { e Pictória do Maestro } \\
\text { Cláudio Santoro* }\end{array}$ & 2009 & Brasília / Plano Piloto & Decreto $\mathrm{n}^{\mathrm{o}} 31.058$, de 20/11/2009 \\
\hline 26. Obra de Athos Bulcão & 2009 & $\begin{array}{l}\text { Brasília / Plano Piloto, Vila } \\
\text { Planalto, } \\
\text { Cruzeiro Novo e Riacho } \\
\text { Fundo }\end{array}$ & Decreto $\mathrm{n}^{\circ} 31.067$, de $23 / 11 / 2009$ \\
\hline $\begin{array}{l}\text { 27. Unidade Vizinhança } \\
107 / 307 \text { e } 108 / 308 \text { Sul }\end{array}$ & 2009 & Brasília / Plano Piloto & Decreto $^{\circ} 30.303$, de 27/04/2009 \\
\hline $\begin{array}{l}\text { 28. Jardins de Burle Marx } \\
\text { em Brasília }\end{array}$ & 2011 & Brasília / Plano Piloto & Decreto $\mathrm{n}^{\mathrm{o}} 33.040$, de 14/07/2011 \\
\hline $\begin{array}{l}\text { 29. Caixa d'água da } \\
\text { Ceilândia }\end{array}$ & 2013 & Ceilândia & Decreto $\mathrm{n}^{\mathrm{o}} 34.485$, de $18 / 11 / 2013$ \\
\hline $\begin{array}{l}\text { 30. Centro de Ensino Médio } \\
\text { - EIT/CEMEIT e Centro } \\
\text { Cultural Teatro da Praça }{ }^{19}\end{array}$ & 2014 & Taguatinga & Decreto $\mathrm{n}^{\mathrm{o}} 35.483$, de $30 / 05 / 2014$ \\
\hline $\begin{array}{l}\text { 31. Templo Budista de } \\
\text { Brasília }\end{array}$ & 2014 & Brasília / Plano Piloto & Decreto $\mathrm{n}^{\circ} 36.166$, de 19/12/2014 \\
\hline
\end{tabular}

No total de 31 bens tombados, 17 estão localizados no Plano Piloto de Brasília. E dentre as atuais 31 Regiões Administrativas, apenas 9 abrigam bens tombados pela Secretaria de Cultura, fora do Plano Piloto. Observa-se que alguns elementos se predispõem a representar o ideário da cidade livre e moderna, mas outros foram inscritos devido à

${ }^{19}$ Conhecido como a antiga Escola Industrial de Taguatinga, o EIT possuía o tombamento provisório, concedido pelo Governo do Distrito Federal, desde o ano de 2007. O decreto $\mathrm{n}^{\mathrm{o}} 28.238$, de 27/08/2007, delimitou como áreas a serem preservadas a do Centro de Ensino e do Centro Cultural Teatro da Praça, pois compunham o núcleo original da antiga EIT. Porém, a inscrição no livro de tombo só aconteceu em 2014, com o tombamento definitivo. 
resistência da população local a fim de garantir sua continuidade histórica, por meio do tombamento.

Tomando-se o conjunto do patrimônio cultural no Distrito Federal, constituído nas duas esferas de governo, tem-se que os mais aludidos pelos meios de comunicação ainda são as edificações localizadas no centro administrativo da Capital, preferencialmente aquelas situadas no entorno do Eixo Monumental. A escolha desses monumentos para a constituição do patrimônio cultural no e do Distrito Federal refletem o modo de atuar dos órgãos governamentais, em especial o Iphan, que desde sua criação privilegia as construções de caráter monumental.

A construção de um universo simbólico a partir do tombamento do patrimônio edificado está legitimada pela ideia de preservar um conjunto de elementos de relevância histórica e cultural, reflexo da memória de uma localidade. Mas como diz Choay (2006) a preservação de monumentos é uma mentalidade que desponta desde o século XIX e que hoje é latente. Como lembra a autora,

Trazendo à memória afetiva a dimensão sagrada das obras humanas, o monumento histórico adquire, além disso, uma universalidade sem precedentes. O monumento tradicional, sem qualificativos, era universalmente difundido, mas fazia reviver passados particulares de comunidades específicas; o monumento histórico fazia até então referência a uma concepção ocidental da história e as suas dimensões nacionais (CHOAY, 2006, p. 141).

Mesmo que a maioria dos bens culturais locais seja eivada dessa pedagogia cívica aludida por Choay, observa-se que começam a aparecer na lista de tombo do Distrito Federal edificações que remetem não apenas à contemplação, mas para o uso cotidiano da população local.

Nunes (2005) nos descreve em Patrimônios subterrâneos em Brasília que o processo de tombamento da Igreja São Geraldo (1983), no Paranoá, e da própria Vila Planalto (1988) só aconteceram devido à resistência popular dos moradores locais à ameaça a seu apagamento de um cotidiano de uma vivência social, gerando assim outra noção de patrimônio.

Assim, da resistência fundada no pioneirismo, enquanto categoria histórica, os moradores desses espaços enfrentam a repressão e a exclusão para conquistarem o direito à cidade que construíram (NUNES, 2005, p. 166). 


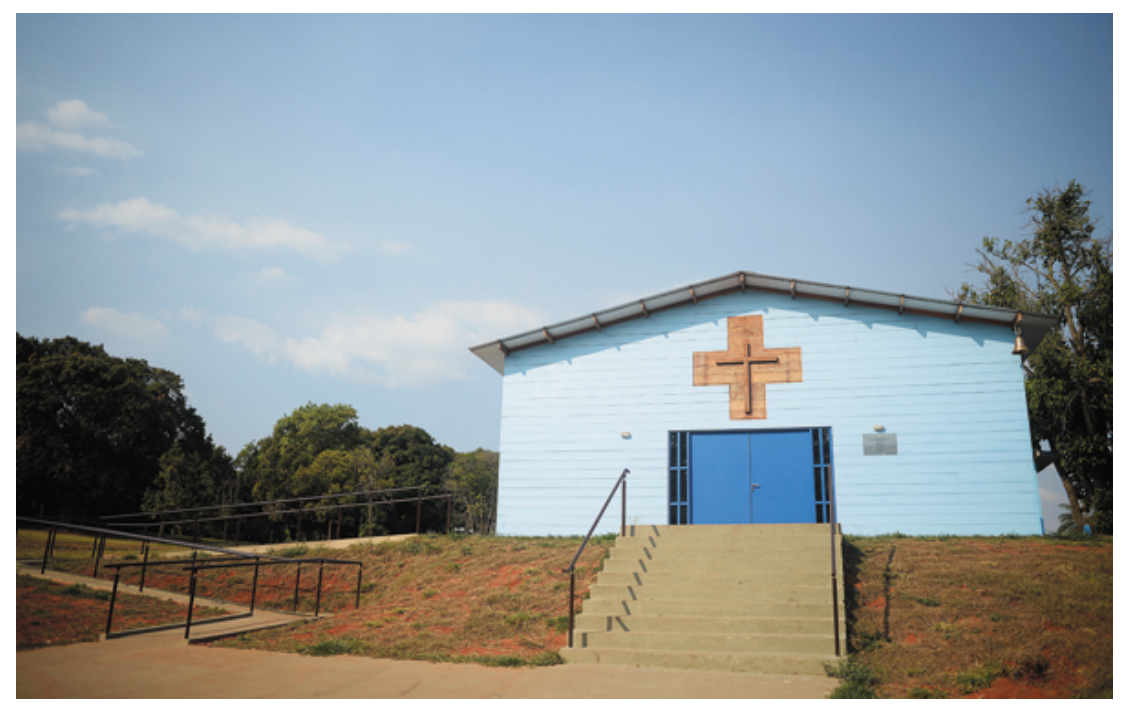

Figura 5 - Igreja São Geraldo ${ }^{20}$ Fonte: Internet ${ }^{21}$

O caráter cívico do patrimônio passa a dividir lugar com sua função de memória de um grupo, reconhecendo outras histórias, permitindo que o patrimônio popular receba também visibilidade social e política. E a partir daí nota-se que, através do tombamento, outras possibilidades de construção de uma relação de identidade com o objeto que se quer preservar se estabelece.

Nunes (2005), ao descrever o caso da Vila Planalto, nos traz outro exemplo de contestação e resistência. O tombamento da Vila, em 1988, representou uma conquista, uma reapropriação de um lugar de memória e história para seus ex-moradores. Ameaçados de perderem o direito à cidade que construíram e viviam, os moradores iniciaram um movimento para reivindicar junto ao poder público a inscrição de parte de suas edificações na lista oficial do patrimônio cultural de Brasília. Desse modo, o tombamento da Vila Planalto provocou estranheza nas elites econômicas e políticos-culturais, cujos olhos sempre estiveram voltados para a arquitetura para a modernidade espacial e arquitetônica de Brasília. O inusitado se deu porque lá não estavam situados monumentos ou edificações de "valor excepcional", mas a

\footnotetext{
${ }^{20}$ A Igreja São Geraldo está localizada no Parque Vivencial do Paranoá. É outra construção em madeira e representativa da resistência da população que habitava o local. Após a construção da barragem (1959), houve a remoção de muitos moradores das vilas ao redor do Lago Paranoá. Na década de 1980, houve um inchaço populacional e a Vila foi considerada a maior invasão do Distrito Federal. Depois de anos de conflito entre o poder público e a população, os moradores ganharam o direito à sua fixação no local. A mobilização pela criação do Parque Vivencial do Paranoá e o tombamento da Igreja São Geraldo são símbolos da resistência popular à violência física e simbólica do Estado.

${ }^{21}$ Foto extraída de http://sites.correioweb.com.br/app/noticia/encontro/revista/2014/09/29/interna_revista,1590/retratos-da-cidadeleilane-menezes.shtml. Acesso em 06/02/2015.
} 
Vila abrigava vestígios da história da cidade vinculados às pessoas comuns, símbolos de sua experiência social. Para o autor (p. 169), as histórias e os patrimônios populares só ganham visibilidade social e política quando seus protagonistas irrompem no cenário histórico, com suas pautas de reivindicações, sendo através das lutas pelos espaços, edificados ou não, sociais ou físicos, que as batalhas são travadas pelo reconhecimento de suas histórias.

Dentre os últimos bens tombados pelo GDF estão a Caixa d'água da Ceilândia (2013) e o Centro de Ensino Médio - EIT/CEMEIT (2014), ambos situados fora de centro políticoadministrativo de Brasília, ambos salvaguardados pela própria reivindicação da comunidade local junto aos órgãos responsáveis pelo tombamento. A partir de iniciativas da comunidade, quando movimentos populares encabeçam o pedido de tombamento junto ao governo local, a discussão sobre a preservação ganha assim novos elementos, distintos dos palácios e ícones arquitetônicos. Dessa forma, vestígios da história de Brasília podem passar também a integrar a lista dos bens dignos de atenção por parte dos órgãos competentes para a gestão do patrimônio histórico, cultural e artístico do Distrito Federal e seus mecanismos de preservação.

A Caixa d'Água da Ceilândia teve seu processo de tombamento iniciado em 2011, pela iniciativa do Fórum de Cultura de Ceilândia. Preocupados com a especulação imobiliária na região, os integrantes dessa organização social propuseram o tombamento como forma de proteger esse símbolo histórico, erguido desde a inauguração da cidade. Observamos que as práticas sociais buscam o fortalecimento da participação cidadã nas estratégias para as cidades, aprofundando a participação democrática em sua gestão visando, dessa forma, dividir os espaços de poder. 


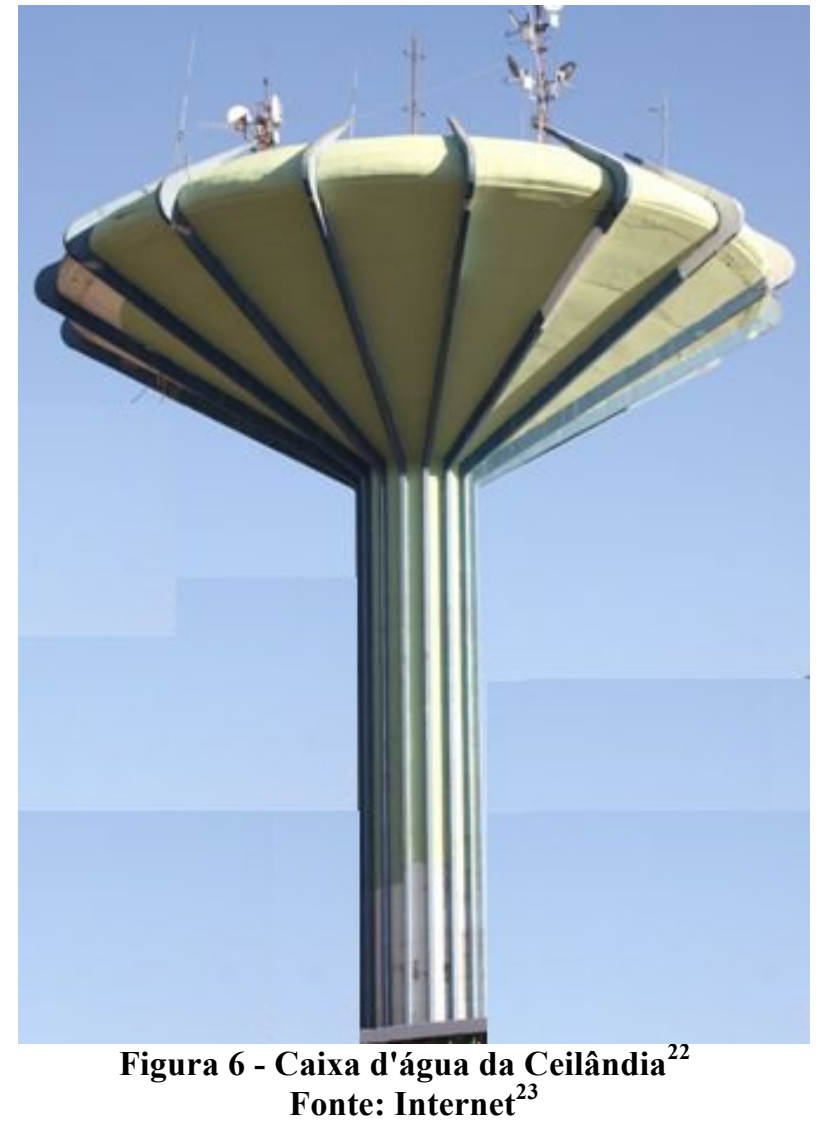

Como vimos, por meio da iniciativa popular, novos bens passaram a fazer parte do cenário do patrimônio cultural do DF, à medida que notamos na presença da lista de bens tombados alguns exemplares representativos da memória daqueles que ajudaram a construir a cidade, fugindo do estereótipo da cidade-monumento, como Brasília é aclamada, representativa do centro do poder e da arquitetura modernista. Essa é uma "...visão míope, que impossibilita descobrir a cidade onde cidadãos comuns constroem e reconstroem suas memórias" (FARIA, 2009, p. 258).

A adoção dessas representações populares fora dos padrões monumentais pode acenar para uma possibilidade de uma história plural de Brasília, "no qual o direito à memória e à história signifique, nesse espaço multicultural, conquista da cidadania, logo, um elemento a mais e vital para a construção de uma sociedade democrática” (NUNES, 2005, p. 200). Pois:

${ }^{22}$ A Caixa d'água da Ceilândia é reconhecida pela população local por sua história e simbologia. O reservatório foi inaugurado em dezembro de 1974 e se tornou endereço de referência da Campanha de Erradicação das Invasões (CEI). A construção transcendeu sua função inicial e se tornou marco da cidade. Mesmo com obras de maior envergadura por perto a caixa d'água, com 30 metros de altura, ainda é um ponto de referência local. Em 1971, a pedra fundamental da nova cidade foi lançada no mesmo ponto onde seria levantado o reservatório, sendo que nesse mesmo dia teve início o processo de assentamento das 20 primeiras famílias. O pedido de tombamento teve como justificativa a descaracterização ou desaparecimento do reservatório por meio da especulação imobiliária. Atualmente a imagem da Caixa d'água é utilizada como logo da cidade em campanhas publicitárias e institucionais.

${ }^{23}$ Foto extraída de http://elyenesantos.blogspot.com.br/2010/05/ceilandia-como-eu.html. Acesso em 15/03/2015. 
O imaginário compõe-se de representações sobre o mundo do vivido, do visível e do experimentado, mas também sobre os sonhos, desejos e medos de cada época, sobre o não tangível nem visível, mas que passa a existir e ter força de real para aqueles que o vivenciam" (PESAVENTO, 2006, p. 50).

\subsection{A gestão e a preservação do patrimônio cultural de Brasília}

São responsáveis pela gestão e preservação do patrimônio cultural localizado no Distrito Federal o Iphan e a Secretaria de Cultura. A esta última cabe a elaboração da política de preservação, promoção e proteção do patrimônio histórico, artístico e cultural do Distrito Federal. A Secretaria é proprietária e detém sob sua custódia 9 dos bens tombados (Tabela 3).

Tabela 3 - Patrimônio Cultural do Distrito Federal

\begin{tabular}{|l|c|}
\hline \multicolumn{2}{|c|}{ PATRIMÔNIO CULTURAL NO DISTRITO FEDERAL } \\
\hline \multicolumn{1}{|c|}{ NOME DO BEM } & $\begin{array}{c}\text { ESFERA DO } \\
\text { TOMBAMENTO }\end{array}$ \\
\hline 1. Museu da Cidade & DISTRITAL \\
\hline $\begin{array}{l}\text { 2. Hospital Juscelino Kubitschek de Oliveira - HJKO } \\
\text { (Museu Vivo da Memória Candanga) }\end{array}$ & DISTRITAL \\
\hline 3. Cine Brasília & DISTRITAL \\
\hline 4. Museu do Catetinho & DISTRITAL / FEDERAL \\
\hline 5. Conjunto Cultural da República & FEDERAL \\
\hline 6. Teatro Nacional Claudio Santoro & FEDERAL \\
\hline 7. Espaço Lucio Costa & FEDERAL \\
\hline 8. Memorial dos Povos Indígenas & FEDERAL \\
\hline 9. Museu da Cidade & FEDERAL \\
\hline
\end{tabular}

Mesmo que pareçam poucas as edificações, em comparação ao conjunto de bens tombados na capital, observamos que a preservação e manutenção desses equipamentos culturais sofrem com a falta de ações públicas que impeçam ou minimizem a ação do tempo e o desgaste advindo de seu uso. Além disso, o funcionamento desses bens depende exclusivamente de servidores da SeCult, que na sua maioria, não possuem capacitação técnica para esse fim. Essas edificações não possuem informações acerca de seu histórico (como folhetos ou folder), sinalização turística, guias bilíngues, como também não apresentam 
programa de educação patrimonial. As informações sobre eles estão geralmente nos sítios dos órgãos governamentais e de empresas que atuam no ramo turístico. Isso acarreta, muitas vezes, no desencontro de informações oficiais no que diz respeito à data de inscrições dos bens, datas de inauguração e de medidas espaciais, bem como o nome dos monumentos. Essa gestão do patrimônio cultural do Distrito Federal demonstra a dissociação dos órgãos governamentais na utilização desse patrimônio como recurso turístico.

Analisando alguns decretos de tombamento, nos deparamos com artigos semelhantes a esse: “A Administração do Distrito Federal, no âmbito de sua competência e nos termos da legislação civil e penal, adotará providências visando à apuração e ao ressarcimento dos danos causados por atos de vandalismo, destruição, deterioração e mutilação que venham a ser praticados contra o bem tombado." Porém, ainda que exista uma legislação que oriente as práticas de preservação do patrimônio local, notamos uma ausência de planejamento para a manutenção desses monumentos e construções históricas, a longo prazo. As ações são quase sempre emergenciais e o abandono é uma das medidas recorrentes.

E diferente de como ocorre com o órgão federal, a Secretaria de Cultura do Distrito Federal não tem poder de polícia para preservar e "defender" os bens tombados que se encontrem ameaçados. Para que ocorra qualquer intervenção para salvaguardar o patrimônio cultural local, é preciso que haja a provocação do Ministério Público do Distrito Federal MPDFT e da Agência de Fiscalização o Distrito Federal - Agefis para atuarem nesse sentido.

Atenta à essa situação, as reações à depredação e ao abandono do patrimônio passaram também a ser de iniciativa popular. Percebemos o apoderamento dos bens culturais pelos moradores da cidade, pois vemos que se instala a noção de que o patrimônio remete à continuidade de uma história vivida e que se vive. O usufruto e, por consequência, sua conservação, promoção e salvaguarda dependem dessa condição.

Como nos diz Nunes (2005), ao descrever o tombamento da Igreja São Geraldo, que deu origem ao Parque Vivencial no Paranoá, mesmo atentos às consequências que irão advir do tombamento (como sua imutabilidade, falta de atuação governamental e alto custo de conservação), iniciativas populares recorrem a esse mecanismo como forma de construir um lugar de memória relacionado ao cotidiano da vida social, gerando outra noção de patrimônio. Para o autor, essa nova noção de patrimônio passa agora pela "construção de uma relação de identidade com o objeto que se quer preservar enquanto memória do grupo" (NUNES, 2005, p. 192). 
No ano de 2010, houve por parte dos "amigos do Cine Brasília" diversas manifestações públicas que exigiam das autoridades a reforma e reabertura do local. $\mathrm{O}$ movimento tomou os meios de comunicação e a mobilização foi realizada pelas redes sociais. O movimento intitulado Ato em defesa do patrimônio cultural do DF não demonstra apenas a preocupação com a preservação da obra de Oscar Niemeyer, mas representa a experiência social possível com o patrimônio cultural. Primeiro cinema da cidade e o maior cinema de rua do Brasil, o Cine Brasília foi tombado em 2007. E desde sua inauguração, já passou por duas reformas, sendo que na última delas entre os anos de 2012 e 2013.

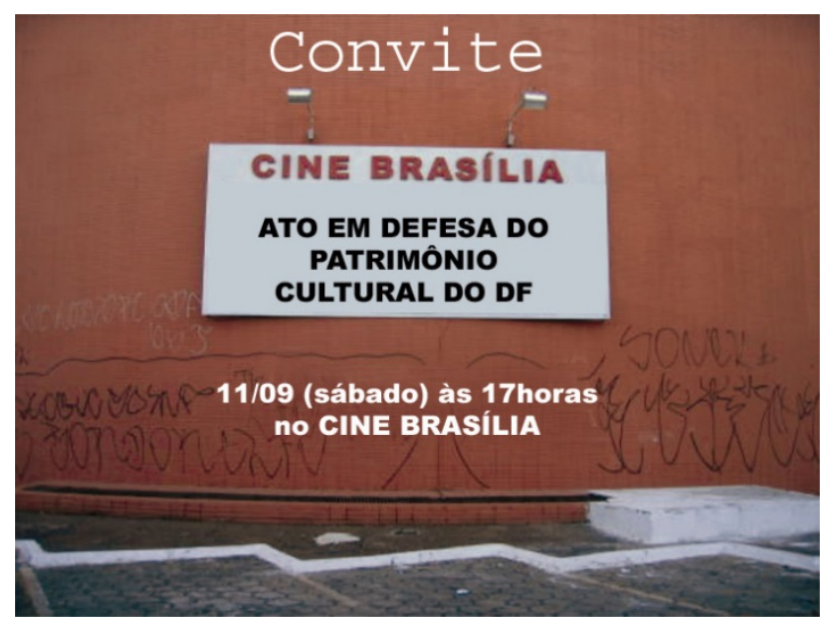

Figura 7 - Convite para o "Ato em defesa do Patrimônio Cultural do DF"24

Notamos que não é apenas pelas edificações isoladas que a população assume o papel de guardião do patrimônio cultural local. Observamos que, quanto ao Conjunto Urbanístico de Brasília, a mobilização para a desaprovação da construção da Praça da Soberania ${ }^{25}$, na Esplanada dos Ministérios, como também em torno da elaboração do Plano de Preservação do Conjunto Urbanístico - PPCUB demonstra a vivência do cidadão e com patrimônio que o cerca.

\footnotetext{
${ }^{24}$ Convite divulgado pela internet pelos "amigos do Cine Brasília". Foto: http://www.culturadigital.br/geografismos/2010/09/08/ato-em-defesa-do-patrimonio-cultura-do-distrito-federal/ 25 A Praça da Soberania é um projeto do arquiteto Oscar Niemeyer para Brasília que não foi concretizado. Trata-se da construção de uma praça localizada no Eixo Monumental, entre o Teatro Nacional Cláudio Santoro e o Conjunto Cultural da República. Em 2009, a proposta foi levada ao então Governador do Distrito Federal, José Roberto Arruda, mas causou muita polêmica e houve um adiamento da construção. Em 2012, o Governador Agnelo Queiroz tentou retomar a discussão em torno da construção, mas pressionado pela rejeição popular, o governo local engavetou o projeto.
} 


\subsection{Brasília como "Patrimônio Cultural da Humanidade"}

Em 1972, com a promoção da Convenção sobre a Proteção do Patrimônio Mundial Cultural e Natural, a Unesco apresentou como um de seus objetivos a reversão da distorção da ênfase do reconhecimento do patrimônio europeu. O organismo pretendia tornar visível o patrimônio cultural ${ }^{26}$ de todas as regiões do mundo, contemplando assim outras realidades globais. E a partir desse momento que Brasília, símbolo de cidade moderna, consegue integrar a lista de Patrimônio Mundial ao lado de "bens históricos com largo prestígio" (CANCLINI, 2012, p. 70).

Contrariando a lógica das cidades históricas, que se tornaram patrimônio por serem datadas no passado e carregarem a função memorial, Brasília com apenas 27 anos de fundação passa a ser também uma referência para a cultura nacional e mundial. $O$ modernismo característico de sua concepção urbana e de seus monumentos, que representam a ideologia desenvolvimentista e que enfatizam a ideia de uma nação que se tornaria industrializada e voltada para o futuro, torna-se o diferencial para atender os critérios da Unesco e a cidade passa a integrar a Lista do Patrimônio Mundial. Ademais, um dos principais motivos que fez com que Brasília se tornasse Patrimônio Mundial foi sua originalidade estética, expressa em sua arquitetura, no contexto do imaginário modernista da época.

Incluindo Brasília, atualmente são nove ${ }^{27}$ as cidades brasileiras inscritas na Lista do Patrimônio Mundial e, desde 1987, quando a Capital recebe a chancela de Patrimônio Cultural da Humanidade, desvela-se através dos discursos oficiais, que proferem a preservação do conjunto urbanístico da cidade, a intencionalidade da utilização do tombamento para o reforço da imagem de "cidade-monumento", visando sua valorização simbólica.

\footnotetext{
${ }^{26}$ De acordo com a classificação da Unesco, são patrimônios culturais obras de arquitetura, escultura e pintura monumentais ou de caráter arqueológico, de valor universal, excepcional do ponto de vista da história, da arte ou da ciência, e ainda obras isoladas ou conjugadas do homem e da natureza, de significativo valor histórico, estético, etnológico ou antropológico.

27 Sítios do Patrimônio Mundial no Brasil, além do Plano Piloto de Brasília: Cidade Histórica de Ouro Preto MG (1980), Cidade Histórica de Olinda - PE (1982), Missões Jesuíticas Guarani, Ruínas de São Miguel das Missões - RS/Argentina, Centro Histórico de Salvador - BA (1985), Santuário do Senhor Bom Jesus Matosinhos em Congonhas do Campo - MG (1985), Parque Nacional Serra da Capivara em São Raimundo Nonato - PI (1991), Centro Histórico de São Luiz do Maranhão (1997), Centro Histórico da Cidade de Diamantina - MG (1999), Centro Histórico da Cidade de Goiás (2001), Praça de São Francisco na cidade de São Cristóvão - SE (2010) e Rio de Janeiro, paisagens cariocas entre a montanha e o mar (2012).
} 
Como afirma Vidal (2009), a relação entre a arquitetura brasileira e a modernização da sociedade sempre esteve presente em todos os níveis de governo que a utilizaram como uma das ferramentas mais importantes para demonstrar seu comprometimento com a criação de um novo país.

Barroso (2008), atenta, que no projeto original da cidade, houve por parte do governo a tentativa de omissão dos vestígios de um país periférico, onde a arquitetura modernista pudesse transportar o Brasil ao patamar de desenvolvimento. Para a autora, "havia no projeto construtor uma espécie de comprometimento com um amplo programa de modernização, no qual a produção de mecanismos de integração dos brasileiros ao mundo moderno era a pretensão" (BARROSO, 2008, p. 44).

Nesse sentido, foi assim que se deu a parceria de Juscelino Kubitschek e Oscar Niemeyer em Belo Horizonte, com a criação da Pampulha, em 1947, como também na construção de Brasília, uma década mais tarde. Porém, foi a modernidade espacial e arquitetônica de Brasília que permitiram se tornar o primeiro bem contemporâneo a merecer a distinção de Patrimônio Cultural da Humanidade.

\subsection{O processo de obtenção do título}

Para a inscrição na Lista do Patrimônio Mundial, além de ter que ser signatário da Convenção do Patrimônio Mundial de 1972, o país interessado deve apresentar um inventário de bens culturais e naturais de seu território para análise e deliberação do Comitê do Patrimônio Mundial. A inclusão de um bem na Lista também depende dele já ser considerado um patrimônio nacional, como também deve haver o consentimento do Estado interessado.

No caso de Brasília, ao candidatar seu conjunto urbanístico para integrar a Lista do Patrimônio Mundial, a proposta foi apresentada pelo Governo Federal, por intermédio do Ministério das Relações Exteriores. A inscrição continha o nome do patrimônio e dos bens que o constituem, sua localização geográfica, as medidas de proteção e a justificativa de seu valor universal excepcional. Na proposta encaminhada, foi mencionado que a cidade foi construída segundo a maneira de pensar o urbanismo proposta por Le Corbusier, sendo aplicada anteriormente apenas em Chandigard, na Índia. Além disso, foi considerado que pelo tamanho do desafio, pela grande escala do projeto e pelos enormes recursos aplicados em sua 
construção, "a criação de Brasília é inquestionavelmente o maior feito na história do urbanismo $^{28 "}$.

Desse modo, a proposta apresentada pelo governo brasileiro, em dezembro de 1986, partiu da iniciativa do governador do Distrito Federal, José Aparecido de Oliveira. A documentação técnica necessária foi elaborada pelo Grupo de Trabalho para Preservação do Patrimônio Cultural do Distrito Federal - GT Brasília, composto por membros especialistas do SPHAN/Pró- Memória, Universidade de Brasília - UnB e GDF. A proposta foi examinada pela direção técnica do Conselho Internacional de Monumentos e Sítios - ICOMOS, a partir de um relatório que enfatizava as principais características e os valores do plano urbano de Brasília, cidade concebida por Lucio Costa, com base nos pressupostos da arquitetura moderna.

Dos critérios estabelecidos pela Unesco para obtenção do título, Brasília se enquadrava em dois:

(i) representar uma obra-prima do gênio criativo humano;

(iv) ser um exemplo de um tipo de edifício ou conjunto arquitetônico, tecnológico ou de paisagem que ilustre significativos estágios da história humana.

Quando o governo local formulou o pedido de inclusão na Lista, a legislação de proteção estava ainda em andamento. Sendo este atraso responsável pela quase rejeição da candidatura da cidade à condição de patrimônio mundial. Em 1987, foi publicado o Decreto $\mathrm{n}^{\mathrm{o}}$ 10.829, para atender ao condicionamento apresentado pelo Comitê do Patrimônio Mundial, onde era exigida a legislação específica para a preservação da concepção urbanística da cidade. $\mathrm{Na} 11^{\mathrm{a}}$ sessão do Comitê, Brasília foi inscrita na Lista do Patrimônio Mundial.

O Plano Piloto está atualmente protegido, tanto a nível distrital quanto a nível federal, nos termos do Decreto $n^{\circ}$ 10.829/19 87 e pela Portaria $n^{\circ}$ 314/1992 do Iphan, respectivamente. Além disso, o Instituto Nacional de Patrimônio Histórico e Artístico Nacional (IPHAN) definiu uma zona tampão com a Portaria $n^{\circ}$ 68/2012.

Com uma extensão de 112,25 km², a área tombada compreende Brasília (RA I), Cruzeiro (RA XI), Candangolândia (RA XIX) e Sudoeste/Octogonal (RA XXII).

Cabem ao Governo do Distrito Federal e ao Governo Federal a responsabilidade compartilhada e a responsabilidade pela gestão e proteção de Brasília por meio da Secretaria de Estado de Gestão do Território e Habitação - Segeth (antiga Sedhab) e o Iphan, respectivamente.

\footnotetext{
${ }^{28}$ Trecho extraído da justificativa para a inscrição na Lista do Patrimônio Mundial. Disponível em: http://whc.unesco.org/archive/advisory_body_evaluation/445.pdf .
} 
O tombamento do Plano Piloto em Brasília é bastante abrangente, pois abriga uma área urbana grande e diversificada. Essa particularidade vem se apresentando como uma dificuldade para a adoção de diretrizes que possibilitem a preservação das características expostas na lei de preservação do conjunto urbanístico que está em constante movimento. Tendo que atender o crescimento populacional com a prestação e serviços.

Nessa perspectiva, a atuação do governo local vem se manifestado por meio de ações que assegurem a manutenção do título de Patrimônio Cultural da Humanidade, procurando atender as recomendações da Unesco. Dentre elas, a implementação do Plano de Preservação do Conjunto Urbanístico de Brasília, o PPCUB.

\subsection{O tombamento e o turismo: uma relação possível?}

A partir da década de 1990, dados oficiais ${ }^{29}$ apontam que, Brasília começa a receber, a cada ano, um número mais significativo de turistas. A propaganda produzida pelo governo local e empresas do ramo turístico, em torno da "cidade com a maior área tombada do mundo" ou do "primeiro bem contemporâneo a merecer a distinção de Patrimônio Cultural da Humanidade" parece não ter tido papel importante para o crescimento da atividade turística na Capital. Faria (2009), ao analisar matérias em jornais de circulação local e nacional sobre a repercussão do tombamento, publicadas nos 20 anos que sucederam à concessão da chancela, nota que o título de Brasília como Patrimônio Cultural da Humanidade não era associado à sua atratividade turística. A autora observou que a maioria das publicações pertencia às seções de Urbanismo e de Infraestrutura e não à seção de Turismo desses veículos. Então qual é a relevância do tombamento do Conjunto Urbanístico de Brasília para o turismo do Distrito Federal? E, particularmente, como o processo de tombamento pode refletir no turismo desenvolvido localmente?

Uma pesquisa $^{30}$ realizada em dezembro de 2012 pela Companhia de Planejamento do Distrito Federal - Codeplan demonstrou que 94\% dos entrevistados tem conhecimento de que

\footnotetext{
${ }^{29}$ Fonte: Secretaria de Estado de Turismo do Distrito Federal

30 Nessa pesquisa a Codeplan realizou 1.769 entrevistas, representando 72.136 moradores da Região Administrativa Brasília - RA-I, no período de maio a julho de 2012. O questionário foi composto por oito questões, a saber: 1 - Tem conhecimento que Brasília possui o título de patrimônio cultural da humanidade? 2 Considera importante o título em questão? 3 - O fato de Brasília ser considerada Patrimônio Cultural da Humanidade ajuda a desenvolver o turismo na cidade? 4 - Acha importante levar aos jovens durante o processo educacional informações relacionadas ao tombamento de Brasília? 5 - Concorda com a afirmação de Lúcio Costa de que "só o tombamento será capaz de garantir no futuro conhecer Brasília tal como foi idealizada"? 6 -
} 
Brasília possui o título de Patrimônio Cultural da Humanidade, $80 \%$ responderam que o título pode ajudar o desenvolvimento do turismo na cidade, mas apenas 56\% responderam positivamente à pergunta Concorda com a afirmação de Lúcio Costa de que "só o tombamento será capaz de garantir no futuro conhecer Brasília tal como foi idealizada? Isso pode indicar que, mesmo reconhecendo a importância do tombamento da cidade, inclusive para o incremento do turismo, a população local se sente provocada em participar e interferir na gerência desse processo.

A conexão do indivíduo com o patrimônio cultural que o cerca acontece pela apropriação dos símbolos e significações desses bens. Como vimos, a constituição do patrimônio do Distrito Federal passa por duas instâncias governamentais, além da cidade também estar inscrita na Lista do Patrimônio Mundial. Porém, essa conexão depende também do posicionamento que esse indivíduo adquire como ser histórico nesse processo de constituição. A partir disso, é possível haver o comprometimento por sua participação enquanto agente atuante, tanto na escolha quanto na valorização de seu patrimônio cultural, representando uma forma de poder compartilhado.

A preservação, promoção e valorização desse patrimônio pelos órgãos governamentais devem ser traduzidas em ações permanentes, com ações integradas nesse sentido, para que se torne uma alternativa de valorização do patrimônio cultural, por meio do qual o turismo tem um de seus ramos de atuação. Isso seria fundamental tanto para a valorização das edificações tombadas no Distrito Federal, quanto para o Plano Urbanístico de Brasília.

O turismo desenvolvido na Capital ainda carece de direcionamento por parte do poder público. Pode-se afirmar que não há em vigor, atualmente, nenhuma ação governamental que integre o patrimônio cultural ao incremento do turismo local. De maneira genérica, a Lei Orgânica do Distrito Federal apresenta diretrizes para o desenvolvimento do turismo na região, pregando a proteção da cultura e patrimônio cultural locais. Já a Secretaria de Turismo do Distrito Federal apresentou em seu Plano de ações (2010) medidas somente de recuperação física dos bens turísticos da cidade. Observamos também a inércia do governo

Considera satisfatória a atuação dos órgãos de fiscalização do GDF, no combate às invasões das áreas públicas de Brasília? 7 - Acha importante a participação da população de Brasília no reconhecimento dos bens culturais da cidade? e 8 - Considera o tombamento do Plano Piloto de Brasília um impedimento para o crescimento da cidade? Os resultados foram correlacionados com as seguintes variáveis por indivíduo: religião, faixa etária, nível de escolaridade, situação de atividade, setor de atividade remunerada, posição na ocupação e estrato de renda domiciliar. 
local na dissociação dos programas federais, como o Plano Nacional de Cultura - $\mathrm{PNC}^{31}$. Esse programa define princípios, diretrizes, objetivos, políticas e metas para o setor cultural para os dez anos seguintes de sua instituição. Possui três eixos norteadores, a saber: (i) a cultura como expressão simbólica, (ii) a cultura como direito de cidadania, e (iii) a cultura como potencial para o desenvolvimento econômico, com foco no fortalecimento dos processos e da participação social. Em janeiro de 2013, a Secretaria de Cultura fez sua adesão ao PNC, onde comprometia-se a implantar no Distrito Federal a estrutura cultual exigida pelo Ministério.

Nessa perspectiva percebe-se a necessidade de um plano turístico, respaldado legalmente, que regule e apresente diretrizes para incentivar o desenvolvimento do turismo na cidade, onde o patrimônio cultural seja tratado como um recurso, ainda é uma dificuldade a ser enfrentada pelo governo distrital. Para tanto é necessário que haja um diálogo constante entre os órgãos públicos responsáveis pela inventariação e salvaguarda dos bens culturais e as empresas de turismo responsáveis pela divulgação do patrimônio à sociedade civil.

\footnotetext{
31 O Plano Nacional de Cultura (PNC) é um programa do Governo Federal, instituído pela Lei n 12.343 , de 2 de dezembro de 2010. Resultado de uma série de seminários, fóruns e consultas públicas organizados no Brasil em 2008, o PNC é composto por 36 estratégias, 275 ações e 53 metas. O Plano é monitorado pelo Ministério da Cultura, seu coordenador executivo, e os dados sobre as políticas culturais são organizados pelo Sistema Nacional de Informações e Indicadores Culturais (SNIIC), ferramenta de mensuração e avaliação das políticas públicas do setor.
} 


\section{CAPÍTULO 3 - A GESTÃO DO PATRIMÔNIO CULTURAL DO DISTRITO FEDERAL: UMA ANÁLISE DA ATUAÇÃO DO PODER PÚBLICO}

Diversos estudos tratam da trajetória da evolução do conceito de patrimônio cultural a partir de seu significado social e como o poder público lida com ele para sua valorização, no âmbito da representação identitária. Isso porque o patrimônio foi assim concebido a partir da Revolução Francesa, quando o entendimento de herança coletiva foi atribuído aos objetos móveis e imóveis e, principalmente, às edificações. Sua relação com a identidade advém principalmente da construção dos Estados Nação, quando resquícios históricos foram determinantes para representar uma tradição territorial.

Nesta pesquisa, procuramos privilegiar o caso brasileiro, sendo o período mais recente, qual seja, depois da criação do Sphan, pois a atuação desse órgão influencia diretamente a gestão do patrimônio cultural do Distrito Federal. Para tanto, conduzimos a análise a partir das seguintes indagações: seria o tombamento, a única e definitiva forma de preservação do patrimônio cultural? Após o tombamento, por que não observamos ações efetivas para sua preservação e valorização? Por que nos deparamos com a falta de apropriação do patrimônio cultural pela população local, quando nos referimos à maioria das edificações tombadas no Distrito Federal? Por que não observamos a articulação entre os diversos órgãos competentes para ações conjuntas no sentido de valorização do patrimônio local?

Quando se trata da constituição do patrimônio cultural do Distrito Federal, existem tendências dissonantes quanto à eleição dos bens a serem tombados, dependendo da esfera governamental que atua. Sendo assim, observamos que os bens tombados pelo Iphan seguem a sua lógica histórica, privilegiando as edificações representativas da arquitetura modernista. Enquanto que em nível distrital, percebemos a influência da iniciativa popular, em alguns casos, no sentido de resguardar suas memórias por meio do tombamento. Como nos diz Choay (2006, p. 112), os "indivíduos e sociedades não podem preservar e desenvolver sua identidade se não pela duração e pela memória”. Assim, o patrimônio cultural do Distrito Federal pode ser caracterizado pela diversidade e pela complexidade para ações no sentido de sua preservação, pois ele está ligado a duas esferas governamentais.

Como o objetivo deste trabalho foi investigar como a gestão do patrimônio cultural do Distrito Federal pode motivar sua valorização e ser fator possível para a promoção do turismo 
local, vale ressaltar que relacionar o patrimônio cultural ao turismo se justifica pelo fato de que aquele não se detém no campo simbólico apenas para os habitantes das cidades que se localizam. O patrimônio cultural também é utilizado como recurso turístico, à medida que observamos que o desenvolvimento do turismo também aponta para a valorização da cultura regional e local. Nesse sentido, características singulares são usadas como mecanismos de diversificação e de exclusividade para o incremento do turismo. E é por meio da patrimonialização que se procura alcançar destaque no mercado turístico nacional e mundial, concedendo status aos destinos que carregam o título de patrimônio oficial.

Com o advento do turismo de massa, foi construída uma imagem negativa desse fenômeno, associando-o ao vandalismo, à destruição dos destinos e da cultural local. Mas é preciso que seja possível a implementação de projetos e programas governamentais, que articulem vários setores e órgãos de diversas esferas para que o patrimônio cultural seja um elemento de fomento para o turismo.

Dessa forma, o interesse maior desta pesquisa foi a análise da gestão do patrimônio cultural do Distrito Federal e como o poder público atua no sentido de sua valorização. $\mathrm{O}$ Conjunto Urbanístico de Brasília foi escolhido para compreender como se dá essa dinâmica, pois o Plano Piloto possui o título de Patrimônio Cultural do DF, Patrimônio Cultural do Brasil e Patrimônio Cultural da Humanidade, servindo de exemplo do processo de sua gestão. Essa observação pode indicar alguns gargalos de tal gestão, como a falta de articulação entre os órgãos competentes, a demora do poder público para agir e a ausência de uma legislação consolidada para tratar do tema.

A decisão de realizar a pesquisa documental deveu-se ao próprio objetivo do estudo. Para detectar as ações públicas para a gestão do patrimônio cultural local, procuramos a análise de documentos oficiais, primordialmente. No caso da pesquisa documental, nos deparamos com algumas dificuldades devido à falta de documentação no Governo do Distrito Federal e a indisponibilidade de alguns dados oficiais. Assim, os dados foram confrontados com pesquisas bibliográficas e relatórios referentes à construção do PPCUB e PDOT com o intuito de proceder à triangulação das fontes no processo de análise.

Sendo assim, exploramos a cronologia da evolução do tratamento dado ao patrimônio cultural, por parte do poder público, representado pelos órgãos responsáveis pelo inventário e salvaguarda dos bens culturais. Nesse contexto, temos, na implantação dos primeiros órgãos governamentais para zelar desse patrimônio, as ações de caráter patrimonialistas, com o objetivo de difundir e preservar as tradições culturais e o patrimônio paisagístico, histórico e 
artístico do país. Na década de 1930, vimos que houve o encontro do discurso do governo com a elite intelectual da época. A criação do Sphan trouxe um novo conceito de políticas culturais com a atuação dos modernistas e intelectuais que atuavam no cenário cultural desta década. A proposta era ampliar o conceito de patrimônio para a formação da identidade brasileira. Porém, o Iphan continuou a privilegiar a o tombamento de edificações, em especial de obras arquitetônicas representantes do modernismo, características da capital. Na década de 1960, vimos as ações governamentais caminharem para o fortalecimento do mercado de bens culturais, com o aumento do volume das produções culturais e o seu alcance a um grande público consumidor. Esse comportamento se repetiu na década seguinte e as políticas voltadas para a preservação do patrimônio passaram a dividir espaço com o mercado cultural.

A constituição do patrimônio cultural do Distrito Federal pode ser acompanhada pela legislação pertinente à sua preservação. Essa construção (da legislação) se deu de forma gradual e ainda está em desenvolvimento. A implantação do PPCUB é mais uma tentativa com esse objetivo e pode resultar em ações possíveis para a preservação, valorização e promoção do patrimônio cultural de forma conjunta, onde a adesão de vários segmentos sociais nessa discussão possibilita a negociação de sua participação na construção desse instrumento, tendo assim, a cidadania resgatada nesse processo.

Assim, o foco da pesquisa recaiu sobre o processo de constituição do patrimônio cultural do Distrito Federal, suas características e sua gestão.

No âmbito distrital, temos que a legislação acerca do Conjunto Urbanístico de Brasília tem origem junto com a inauguração da cidade. A Lei Santiago Dantas (Lei no 3.751/1960), que dispõe sobre a organização administrativa do Distrito Federal já definiria que qualquer alteração no Plano Piloto dependeria de lei específica. Apenas em 1987, com a publicação do Decreto $n^{0} 10.829$ é que são estabelecidos critérios para a ocupação do Plano Piloto. Nota-se que esse decreto é elaborado a partir do texto Brasília Revisitada e para atender a exigência da Unesco de uma legislação de preservação para a concessão do título de Patrimônio Cultural da Humanidade. Quanto aos bens tombados pelo GDF, temos a Lei $n^{\circ} 47$, de 1989 , regulamentada pelo Decreto ${ }^{\circ} 25.849$, de 2005 .

\subsection{A gestão do patrimônio cultural no Distrito Federal}


Brasília como símbolo de um novo Brasil, deveria ser lembrada como uma imagem associada a ideia de progresso cultural, econômico e social. O projeto de Lucio Costa e a arquitetura de Oscar Niemeyer eram a demonstração da originalidade brasileira, incutindo a impressão da identidade nacional.

A Capital foi o primeiro bem contemporâneo a merecer a distinção de Patrimônio Cultural da Humanidade e é representante emblemática da arquitetura moderna.

Notamos que desde o início da gestão cultural em Brasília houve a predominância das manifestações das elites que faziam parte das classes privilegiadas, sendo que a cultura popular recebia pouca visibilidade, contrariando o plano original de cultura da cidade. E a gestão do patrimônio edificado não fugiu a essa lógica.

Ao analisar as duas tabelas dos bens tombados no Distrito Federal, pelo Iphan e pelo GDF, constantes no Capítulo 2 deste trabalho, observamos que os 51 bens tombados são expressivamente representantes da arquitetura modernista, mais especificamente com 26 obras de Oscar Niemeyer. Notamos que ocorre uma tentativa de equilíbrio nas listas de tombo para reverter essa distorção, pelo menos em nível distrital, à medida que novos elementos, constituintes da construção da cidade, foram integrados ao patrimônio cultural do Distrito Federal, a exemplo da Caixa d'água da Ceilândia e a própria Vila Planalto, como vimos. O Gráfico 1 demonstra a distribuição dos bens tombados pelo Iphan por sua classificação.

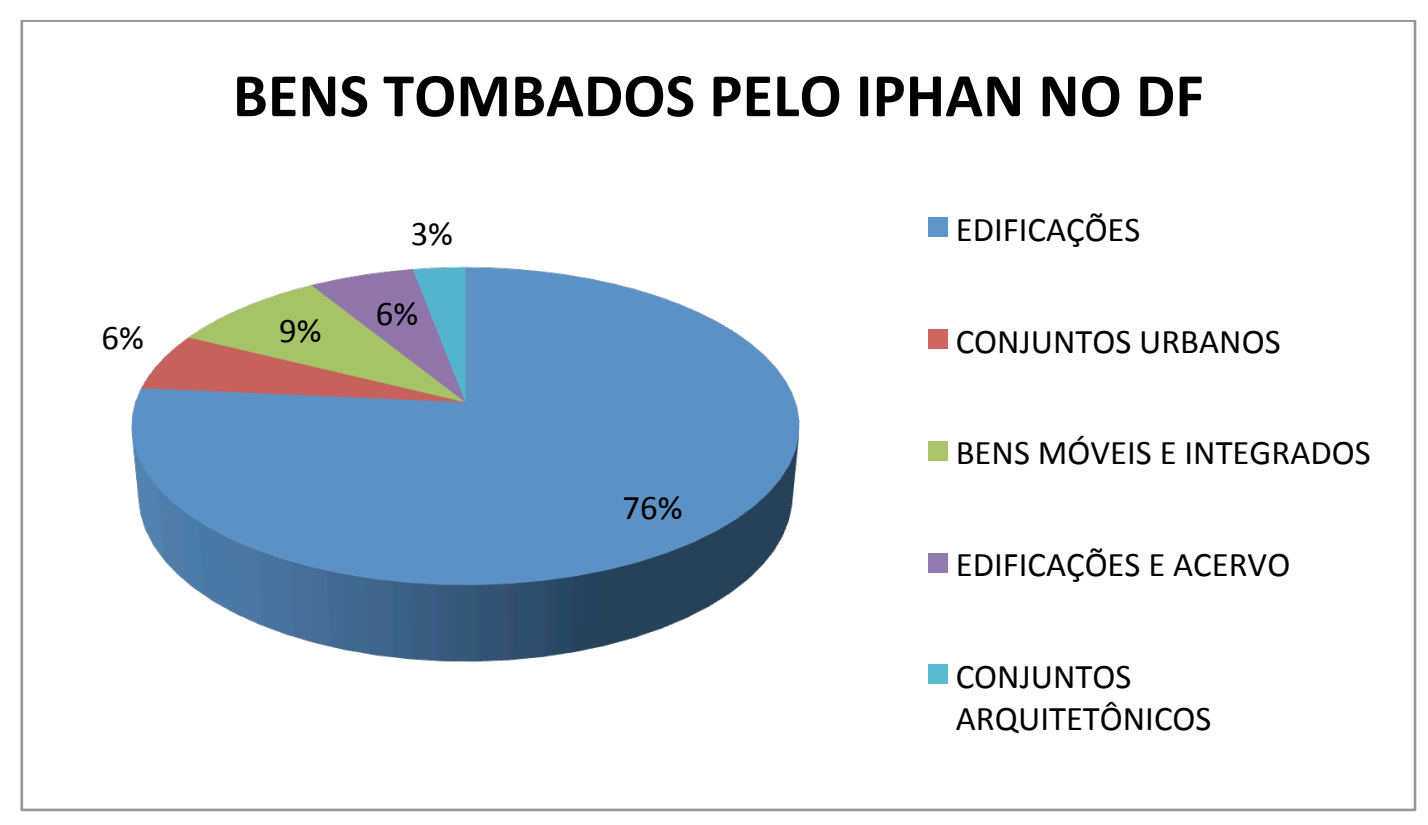

Gráfico 1 - Bens Tombados pelo Iphan 
Notamos também, ao analisar as tabelas citadas, que apenas 14 bens se encontram fora do Plano Piloto, o que corresponde a $38 \%$ da totalidade. O Gráfico 2 demonstra a disposição desses bens no Distrito Federal.

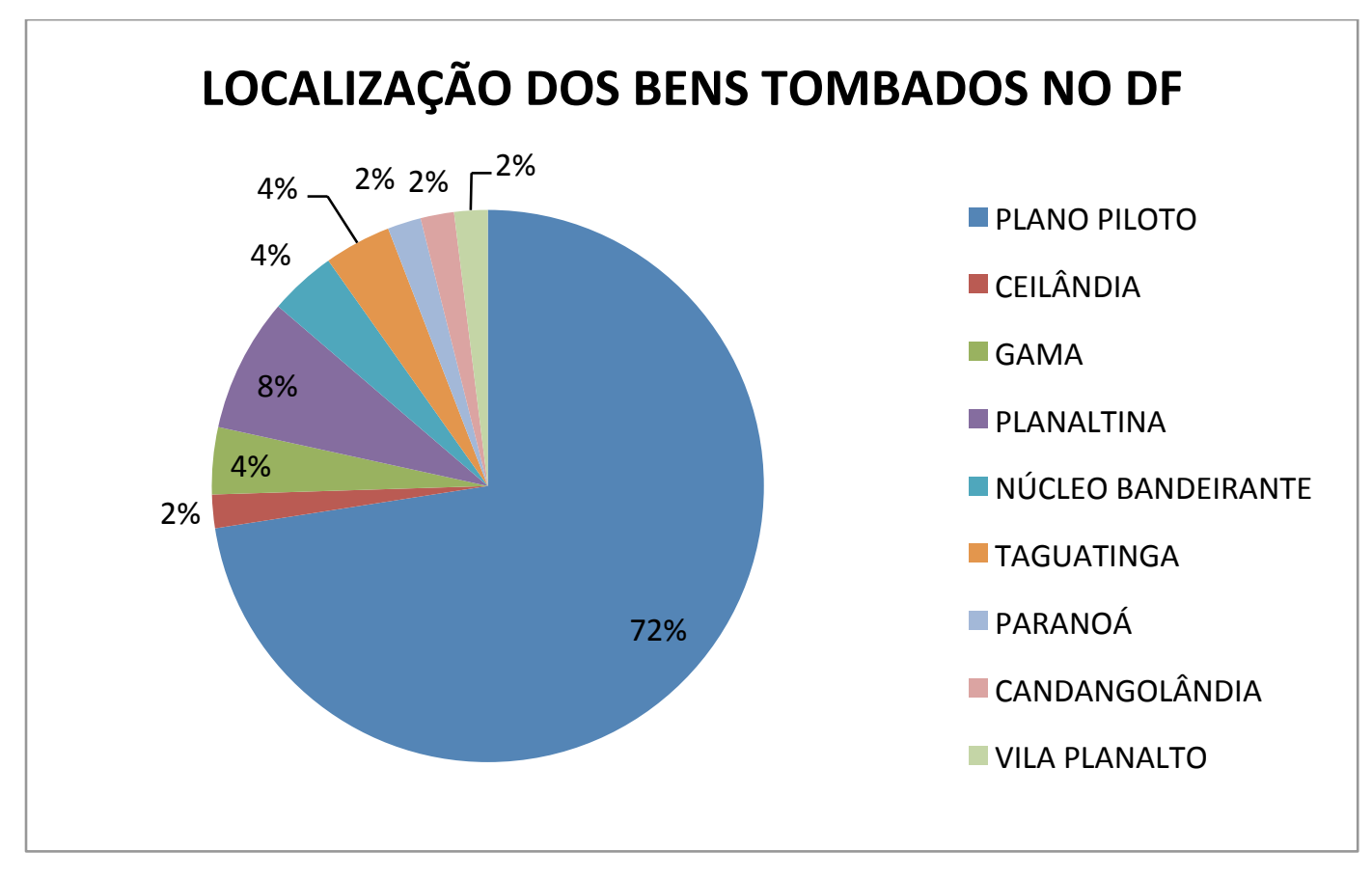

Gráfico 2 - Localização dos bens tombados

À época da inauguração de Brasília, a política cultural adotada pelo Iphan sofria críticas por ser pouco representativa da diversidade cultural brasileira, onde eram privilegiados pelo Órgão, preferencialmente, obras do movimento barroco brasileiro.

Como afirma Ortiz (2012), os intelectuais que atuavam no Órgão insistiam na preservação das expressões e manifestações do passado. O Estado continuava privilegiando o acervo histórico, deixando as atividades mais populares delegadas à indústria cultural que surgia no país. A proteção legal às manifestações populares foram adquirindo volume com o tempo, sendo o caso do tombamento do Terreiro Casa Branca do Engenho Velho pelo Iphan (1984) a expressão emblemática da pressão popular para o reconhecimento de um "outro patrimônio cultural". Porém, foi com a promulgação da Constituição Federal Brasileira, em 1988, que foram apresentados dois princípios como parte dos direitos culturais dos brasileiros, sendo eles: o princípio da cidadania cultural e o princípio da diversidade cultural. A partir de então, as expressões culturais não eruditas foram sendo incorporadas às listas de tombo, mesmo que de forma tardia, por meio da reivindicação de determinados grupos sociais que não se viam representados naquele patrimônio. 
Brasília como ícone do modernismo, poderia atrair os olhares do corpo técnico do Iphan, mas o tombamento de bens localizados na capital teve seu processo acelerado a partir do tombamento de seu conjunto urbanístico.

Como vimos, o primeiro bem localizado no Distrito Federal a ser tombado foi o Catetinho (1959), mesmo antes da inauguração da cidade. Vemos que a atuação do Estado já confiava ao tombamento o papel de garantia e salvaguarda. Nesse caso, pela maior fragilidade de sua construção e por sua importância histórica.

O Catetinho foi tombado pelo processo $n^{0}$ 594-T-59 e teve sua inscrição no Livro de Tombo Histórico do Sphan, na folha 55, sob a inscrição no 329, em 21/07/1959. O pedido partiu do presidente Juscelino Kubitscheck sob a justificativa "por ter sido não só a primeira construção erigida na área da nova capital, mas também a primeira sede da administração pública no local" ${ }^{32}$.

Até o ano de 1982, quando o primeiro bem é tombado pelo governo distrital - a Igrejinha - na capital só havia duas edificações nessa condição: o Catetinho e a Catedral (ambos pelo Iphan). Até o final de 2014, vimos que o GDF procedeu com o tombamento para 31 bens, sendo que cabe a Secretaria de Cultura a gestão de apenas 9. Mesmo assim, percebemos que os instrumentos legais são insuficientes. A falta de destinação financeira sistemática para projetos de revitalização e promoção desses bens é um dos gargalos que encontramos na gestão patrimônio cultural do Distrito Federal.

Podemos citar o Fundo de Desenvolvimento Urbano do DF - Fundurb como uma forma possível de viabilizar projetos, com a captação e destinação de recursos, para a preservação do patrimônio existente na área de tombamento de Brasília. O Fundurb trata-se de um fundo de natureza contábil e é gerido pela Secretaria de Gestão do Território e Habitação do Distrito Federal - Segeth. A exemplo disso, temos que a última reforma do Cine Brasília (2011-2012) e a restauração da Igreja São Geraldo (Paranoá), foram financiadas com recursos desse Fundo. Porém, não observamos, por parte do poder público, ações sistemáticas para a conservação e promoção dos bens localizados no Distrito Federal.

Como consta no relatório emitido pelo Tribunal de Contas do Distrito Federal - TCDF, de 2012, realizado após a avaliação de recursos públicos destinados para obras e manutenção dos bens públicos locais, a organização da "atividade de manutenção das edificações públicas

32 Trecho retirado do ofício $\mathrm{n}^{\mathrm{o}}$ 358, encaminhado pelo Diretor do Patrimônio Histórico e Artístico Nacional, Rodrigo Melo Franco de Andrade, ao então Presidente da Companhia Urbanizadora da Nova Capital - Novacap, em 15/10/1958. (ANEXO III) 
do DF é realizada de maneira improvisada e casual e não garante a integridade das edificações públicas" (p. 18). O documento ainda nos revela a causa identificada pela auditoria da má gerência do patrimônio público, sendo que

\begin{abstract}
A causa identificada para o achado é a inexistência de procedimentos sistematizados, uniformes e amplamente disseminados no GDF para as atividades de manutenção de bens públicos. Em especial, não existe rotina de inspeção e avaliação da situação dos bens para fins de planejamento aderente àquela norma. Também não existem planos de manutenção preventiva ou corretiva semelhantes aos preconizados na ABNT NBR 5674. Ao contrário, as ações de manutenção observadas são tardias e meramente reativas, empreendidas tão-somente para responder a emergências identificadas. (...) da mesma forma, inexistem normas definindo responsabilidades, competências, prazos e produtos da atividade de manutenção dos bens públicos; bem como não existem manuais definindo procedimentos para a manutenção de cada bem." (p. 19)
\end{abstract}

Alguns bens tombados foram também vistoriados durante a auditoria, que identificou:

- Teatro Nacional Claudio Santoro - "evidenciou graves falhas no sistema de manutenção, necessitando de reparos urgentes. Embora exista contrato de manutenção (Contrato de Prestação de Serviços no 017/2009-SC), desde 16/04/2009, no Teatro foram encontradas portas de acesso à sala Martins Pena e ao Espaço Dercy Gonçalves quebradas, vigas estruturais apresentando rachaduras, sinais de infiltração no telhado e nas paredes externas, mofo no carpete, elevadores fora de serviço, sistema de ar condicionado causando insalubridade (soltando lã de vidro) e cubos decorativos das paredes externas sem a devida impermeabilização, apesar de terem sido recentemente trocados. Também, constatou-se que o espaço reservado para restaurante no topo do edifício está desativado e os camarins estão em péssimo estado de conservação." (p. 23)

- Museu Nacional do Conjunto Cultural da República: "apresentou graves falhas na sua manutenção. Trincas e rachaduras aparentes com sinais de infiltração em todas as estruturas visitadas, sistema de ar condicionado sem contrato próprio de manutenção, elevadores quebrados e sem contrato de manutenção foram os principais problemas detectados pela auditoria." (p. 24)

Nesse mesmo relatório, o TCDF aponta que a restrição orçamentária é o maior problema para a deterioração das edificações analisadas, sendo que de 2008 a 2011 o investimento para as ações de conservação do patrimônio público tem se mostrado 
decrescentes. Mas ele preconiza que, apesar dessa dificuldade, a Secretaria de Cultura "não adota procedimentos adequados na manutenção dos bens públicos sob sua tutela." (p. 31). E, além disso, na opinião dos conselheiros, a limitação também percebe-se na formação de recursos humanos para o trabalho de preservação e gestão do patrimônio cultural, em âmbito distrital, como também na estrutura necessária aos servidores para cumprir todas as atribuições definidas em lei.

Mesmo que o relatório do TCDF nos demonstre a ausência de planejamento dos órgãos na atuação em defesa do patrimônio público e, consequentemente, do patrimônio cultural do Distrito Federal, entendemos que a articulação entre os entes participantes da Administração Pública se apresente como de grande importância para a reversão desse quadro. É preciso que se estabeleça as atribuições definidas para que a preservação desse patrimônio seja menos onerosa, tanto no ponto de vista financeiro quanto operacional. Além disso, há uma separação da autuação do poder público local quando nos reportamos ao Conjunto Urbanístico de Brasília e aos outros bens tombados. A nível distrital, para o primeiro, temos que a responsabilidade está com a Segeth e para as outras edificações, a atribuição de preservá-las fica a cargo da Secretaria de Cultura. Dessa forma, não observamos ações integradas que possam atingir o patrimônio cultural na sua totalidade, onde seja possível sua preservação e promoção. Apesar da possibilidade de recorrer aos recursos do Fundurb para a restauração do patrimônio local, observamos que a ausência de destinação financeira específica e implementação de ações sistemáticas para sua conservação tornam sua gestão ineficaz, à medida que o poder público opera de forma emergencial. Além disso, entendemos que a recomendação do TCDF para que se sejam adotadas medidas de conservação preventivas, ao menos nas edificações sob custódia do GDF, seria um reflexo para a promoção desse patrimônio e do turismo local, uma vez que a ação de um órgão público, nesse sentido, legitima o caráter simbólico de um bem e, por conseguinte, sua apropriação pelo turismo.

Como vimos, apesar de representar um potencial turístico na Capital, o patrimônio cultural ainda sofre com a omissão do poder público local para sua promoção. Porém, conseguimos detectar algumas tentativas, de articulação conjunta, em consolidar o patrimônio como recurso turístico.

Trazemos como exemplo o programa "Turismo Cidadão". Lançado em abril de 2014, pela Secretaria de Turismo, o programa era focado no turismo cívico e objetivava apresentar a centro administrativo e monumentos da cidade. O público-alvo se compunha de estudantes do 
Ensino Médio, grupos de riscos e idosos. Entraram como parceiros para implementação do programa a Secretaria de Educação, Secretaria do Idoso, Sedest, Unesco e TCB. O programa teve duração até dezembro de 2014 e não obtivemos informação do público atingido.

Vemos nesse caso, que o programa se destinava essencialmente aos moradores da cidade que desconheciam seus monumentos, mas poderia ser uma iniciativa refletida ao turista convencional, na medida que esses visitantes locais, apropriados de seu patrimônio, pudessem replicar suas experiências a parentes e amigos. O programa foi lançado com pompa devido à aproximação da Copa do Mundo de Futebol e contou com a presença do cartunista Ziraldo, que ilustrou uma cartilha distribuída aos usuários. Porém, o "Turista Cidadão" foi interrompido quando houve a troca de governo. A falta de continuidade dos programas governamentais e a ausência da atuação da Secretaria de Cultura são outros gargalos que observamos na promoção e valorização do patrimônio local.

Assim, no âmbito governamental, é preciso que a relação entre as suas instituições, como a Secretaria de Cultura e a Secretaria de Turismo, ultrapasse a dimensão puramente administrativa e passe a ser uma relação política, na medida em novos programas que aliem patrimônio cultural e turismo possam ser implementados. Como o patrimônio cultural é de interesse de toda a população, é preciso propor novas formas de gestão. Os resultados positivos na valorização do patrimônio cultural prescindem da participação de diferentes atores, como a sociedade civil, a iniciativa privada, as instituições de ensino e o setor público. Ações que levem em conta essa articulação, podem trazer ao turismo uma dimensão mais humanizada, a partir do momento que ele deixa de ser apenas um produto do mercado para se tornar uma experiência.

Como vimos, já existe por parte da população de Brasília o reconhecimento de seu acervo tombado. Mesmo que em alguns casos haja o distanciamento entre a atuação oficial a respeito da memória que se pretende preservar, cremos que a partir desse reconhecimento é que se dará a apropriação por parte dos moradores, onde o zelo e a promoção desse patrimônio ocorrerão de forma natural. Para isso, é preciso que a atuação do poder público seja mais eficaz, no sentido de garantir que isso aconteça, pois observamos que no nível local, a maioria dos bens tombados está sob a custódia governamental.

A dispersão das atribuições entre os entes oficiais, a ausência de responsabilização dos gestores públicos, a falta de planejamento para a aplicação orçamentária e a ausência de programas e projetos que possam ser implementados para a gerência desse patrimônio 
atrelado ao desenvolvimento do turismo, fazem com que o patrimônio cultural do Distrito Federal seja gerido de forma ineficiente.

Atualmente, o processo de tombamento fica a cargo da SeCult, porém a fiscalização dos bens tombados é atribuição da Agefis. O Conjunto Urbanístico de Brasília deve ser monitorado pela Segeth em parceria com o Governo Federal, representado pelo Iphan. A Secretaria de Turismo se atém a programas de segmentos, onde podemos destacar o chamado turismo de eventos, característica natural da Capital.

Os programas não tem prosseguimento com as mudanças de governo. As pressões para desvinculá-los do agente político não permitem a avaliação para avaliá-los e melhorá-los, nem muito menos sua consolidação.

Ainda prevalece na Administração Pública local a cultura da inauguração de obras, deixando o patrimônio público sem o amparo necessário para sua manutenção. Como nos demonstrou o relatório do TCDF, há uma tendência dos gestores públicos em realocar recursos financeiros para a construção de novas edificações em detrimento da manutenção dos monumentos já erguidos, provocando o sucateamento desses bens.

A prática rotineira é a interdição para uso por falta de manutenção. Falta de autonomia da SeCult para intervir, orçamento para as ações de preservação, implementação do programa de valorização (como o de Educação Patrimonial) e capacitação dos servidores. Nesse sentido, a cartilha "Patrimônio cultural: educar para preservar" (ANEXO I), elaborada em 2013, foi a única iniciativa encontrada para atingir as crianças e adolescentes da rede pública de ensino. Porém, não obtivemos informações quanto à distribuição desse material.

Lembramos que em 2013, a Secretaria de Cultura do Distrito Federal teve sua última alteração administrativa. Na ocasião, foi criada a Gerência de Patrimônio Imaterial, sendo que essa ficou subordinada à Subsecretaria de Diversidade Cultural, o que a fez perder seu vínculo da Suphac, Subsecretaria que tem a competência legislativa para responder sobre o patrimônio do Distrito Federal. Essa confusão administrativa também impede o desenvolvimento de ações públicas eficientes, que efetivamente protejam e promovam o patrimônio local.

Como vimos, desde a criação da Divisão de Patrimônio Histórico e Artístico do Distrito Federal, no Departamento de Cultura, ligado à então Secretaria de Educação e Cultura, havia por parte do governo local a preocupação em inventariar e preservar os bens culturais de relevância histórica e cultural. Mas as mudanças constantes acerca das atribuições relegadas à Secretaria de Cultura nos faz inferir que a gestão do patrimônio cultural ainda 
passa por um processo de construção. Como disse o Secretário de Cultura (2010-2014), Hamilton Pereira, em entrevista ao jornal Correio Braziliense sobre a proposta de criação do Instituto do Patrimônio Artístico e Cultural - Iphac ${ }^{33}, "$ "... a sociedade não sabe nem sequer de quem pode cobrar providências." ${ }^{34}$ Sabemos que o tombamento acarreta o ônus de sua preservação, mas ainda são difusas as atribuições quanto à sua fiscalização e proteção, dentre os órgãos governamentais locais.

No site oficial do Iphan pudemos achar a relação de bens tombados pelo órgão no Distrito Federal. Algumas informações foram complementadas por meio de correspondência eletrônica no e-mail institucional da Superintendência do Iphan no Distrito Federal (iphandf@iphan.gov.br). A informação da data de início do processo de tombamento da Pedra Fundamental em Planaltina, ausente na relação do site, nos foi encaminhada pelo Fale Conosco/Iphan por e-mail, sendo esta a resposta do Órgão:

\begin{abstract}
A Pedra Fundamental não possui processo de tombamento aberto ainda. O que temos é uma solicitação de tombamento, que precisa ter o dossiê com todas as informações para a formalização da abertura do processo. O IPHAN está aguardando que os representantes da sociedade civil, solicitantes enviem o material de pesquisa já existentes sobre o objeto - pedra fundamental. Após a reunião desse material o IPHAN DF emitirá seu parecer e enviará às instâncias superiores.
\end{abstract}

Quanto à expressão RERRATIF., encontrada no campo sobre a situação do bem, para o Conjunto Urbanístico de Brasília, a explicação também se deu por e-mail, sendo que o Iphan esclarece que "o processo de tombamento do conjunto Urbanístico de Brasília está na superintendência do Iphan no Distrito Federal para realização de estudos que visam a rerratificação da poligonal de tombamento."

Alguns pontos nos chamaram a atenção na pesquisa, como por exemplo, a diferença da constituição do patrimônio cultural do Distrito Federal pelas duas esferas (federal e distrital).

A análise feita desta relação nos permite ratificar o comportamento do órgão quanto ao tombamento, que se destina ainda essencialmente a edificações monumentais. Dos 34 bens

\footnotetext{
${ }^{33}$ O Instituto do Patrimônio Histórico, Artístico e Cultural - Iphac seria um organismo para preservação da área tombada de Brasília, vinculado à Secretaria de Cultura. 0 trabalho desempenhado pelo Iphac seria semelhante ao do Iphan. A proposta de Projeto de Lei foi formulada em 2011 e deveria ser encaminhada à Câmara Legislativa do DF. Porém, o Instituto não foi implantado até o momento.

${ }^{34}$ Trecho retirado da matéria "Mais proteção ao patrimônio", publicada no jornal Correio Braziliense em 25/11/2011, Seção Cidades, p. 27.
} 
tombados, 26 estão localizados na área do conjunto urbanístico da cidade, sendo que 23 tiveram seu processo de tombamento iniciado no ano de 2007. Esse dado nos permite fazer uma estreita relação entre a primeira Missão de Monitoramento Reativo, enviada pela Unesco a Brasília em 2001 e as ações na tentativa de que, através da preservação por meio do tombamento, pudesse ser assegurada a manutenção do título, em face à inércia do governo local. A salvaguarda do Conjunto Urbanístico teve seu início efetivo com a publicação do PDOT, em 2009.

Para o Iphan, os bens que integram sua lista de tombo se constituem essencialmente de monumentos representantes da arquitetura moderna, localizados na área tombada de Brasília (o conjunto urbanístico). Eles caracterizam a escala monumental presente no projeto original da cidade. Poucas dessas edificações tiveram a iniciativa popular para o início tombamento, pois carregam a monumentalidade como sua maior expressividade. Quando analisamos o tombamento realizado pelo GDF verificamos que aparecem na lista uma maior heterogeneidade quanto à constituição desse inventário. Mesmo apresentando muitas edificações religiosas e outras coincidentes com a lista do Iphan, no Distrito Federal que alguns bens (mesmo que ainda numa pequena proporção) se localizam fora do Plano Piloto. Nesse sentido, constatamos uma maior representação no patrimônio cultural da cidade daquelas edificações que se tornaram significativas também para a população na construção da Capital.

Outro dado que nos chamou a atenção é que, até o final de 2014, a maioria dos 34 bens possuem seus processos de tombamento ainda em fase de instrução no Iphan e apenas 3 tiveram o tombamento efetivado. Diferente do que aconteceu com o Conjunto Urbanístico de Brasília, que teve sua inscrição e aprovação no mesmo ano. Ribeiro (2004) nos exemplifica essa distinção de tratamento ao comparar o processo de tombamento do Hospital Juscelino Kubistchek de Oliveira - HJKO e o tombamento de Brasília. Para a autora,

(...) apesar de inúmeros relatórios com toda a documentação e pareceres técnicos favoráveis e da importância da área para a história da construção de Brasília, o tombamento do HJKO ainda não foi decidido pelo IPHAN, ao contrário da rapidez dos procedimentos relativos ao tombamento de Brasília e sua homologação, em 1990. Os diferentes tratamentos dispensados aos dois objetos - o Plano Piloto de Brasília e o HJKO - demonstraram, por parte do IPHAN, a opção pelos valores da classe dominante na escolha dos bens a serem protegidos. Os detentores do capital cultural e social ditam as regras e os critérios de seleção dos bens culturais (RIBEIRO, 2004, p. 85). 


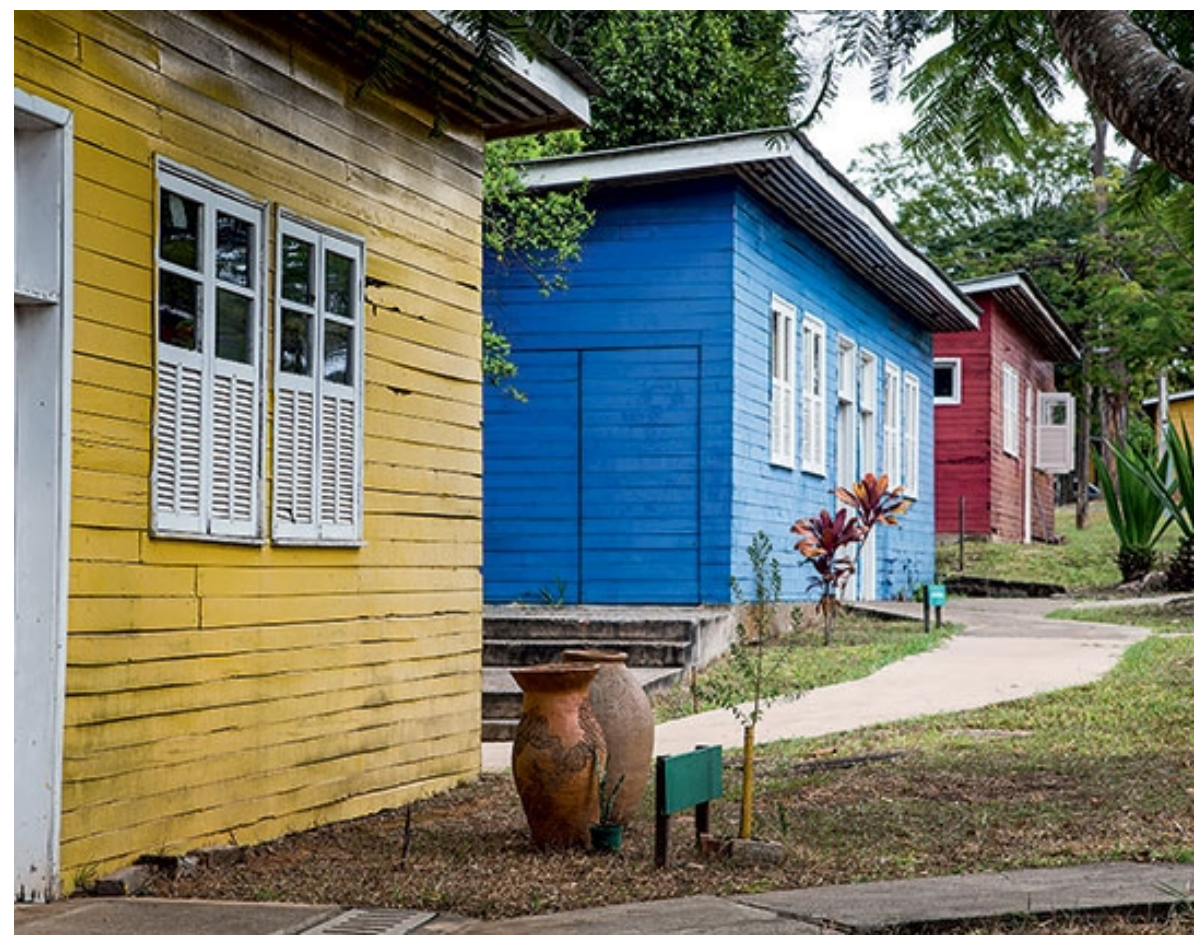

Figura 7 - Hospital Juscelino Kubistchek de Oliveira - HJKO

Fonte: http://www.cultura.df.gov.br

Dessa forma, observamos que para o órgão nacional as edificações relevantes da época da construção, os designados "patrimônios subterrâneos" por Nunes (2005), ainda são preteridos ante aos monumentos arquitetônicos que permeiam a cidade e à sua própria concepção urbanística.

Porém, a obtenção do título de maior área tombada do mundo amplifica as polêmicas entre as ações de desenvolvimento da cidade e os esforços para a preservação original do plano original de Lucio Costa. Nesse sentido, o governo local, após receber recomendações da Unesco para manutenção do título e pela falta de critérios mais definidos para esse desenvolvimento, está trabalhando para a elaboração do PPCUB a fim de determinar diretrizes para a preservação do conjunto urbanístico da Capital.

\subsection{As ameaças ao título e a contribuição popular: as recomendações da Unesco e o PPCUB}

Mesmo que Brasília nunca tenha entrado para a lista do patrimônio mundial em perigo, desde a obtenção do título, a cidade vem sofrendo com o crescimento populacional e às pressões sobre a área tombada. 
Como nos reporta o relatório da $24^{\mathrm{a}}$ sessão do Comitê do Patrimônio Mundial, em 2010 já havia a preocupação da Unesco com o crescimento desordenado, mas foi observado à época que o sítio tombado ainda mantinha-se intacto. Porém, a atenção começava a voltar-se para essa ameaça. O relatório diz:

O ICOMOS enfatizou a necessidade de uma missão para investigar as ameaças ao ambiente do local. Em resposta, o observador do Brasil afirmou que, embora houvesse tido o aumento da pressão demográfica, as construções se concentraram em áreas fora do Plano Piloto, o que não representa ameaça à integridade do Patrimônio Mundial local" (WHC2000/CONF.204/21 p. 126). ${ }^{35}$ (Tradução nossa).

A pressão demográfica, assim como as construções irregulares, poderiam representar ameaças para a perda do título, à medida que as características que asseguraram essa condição sejam adulteradas.

A Unesco, em suas sessões do Comitê do Patrimônio Mundial vem reportando as mudanças sofridas na área tombada, bem como orientando as instituições brasileiras para ações de preservação.

35 Trecho original: ICOMOS emphasized the need for a mission to investigate reports on the threats to the environment of the site. In response, the Observer of Brazil stated that even though there was increased demographic pressure, construction activity concentrated on areas outside the main urban design, did not threaten the integrity of the World Heritage site. 


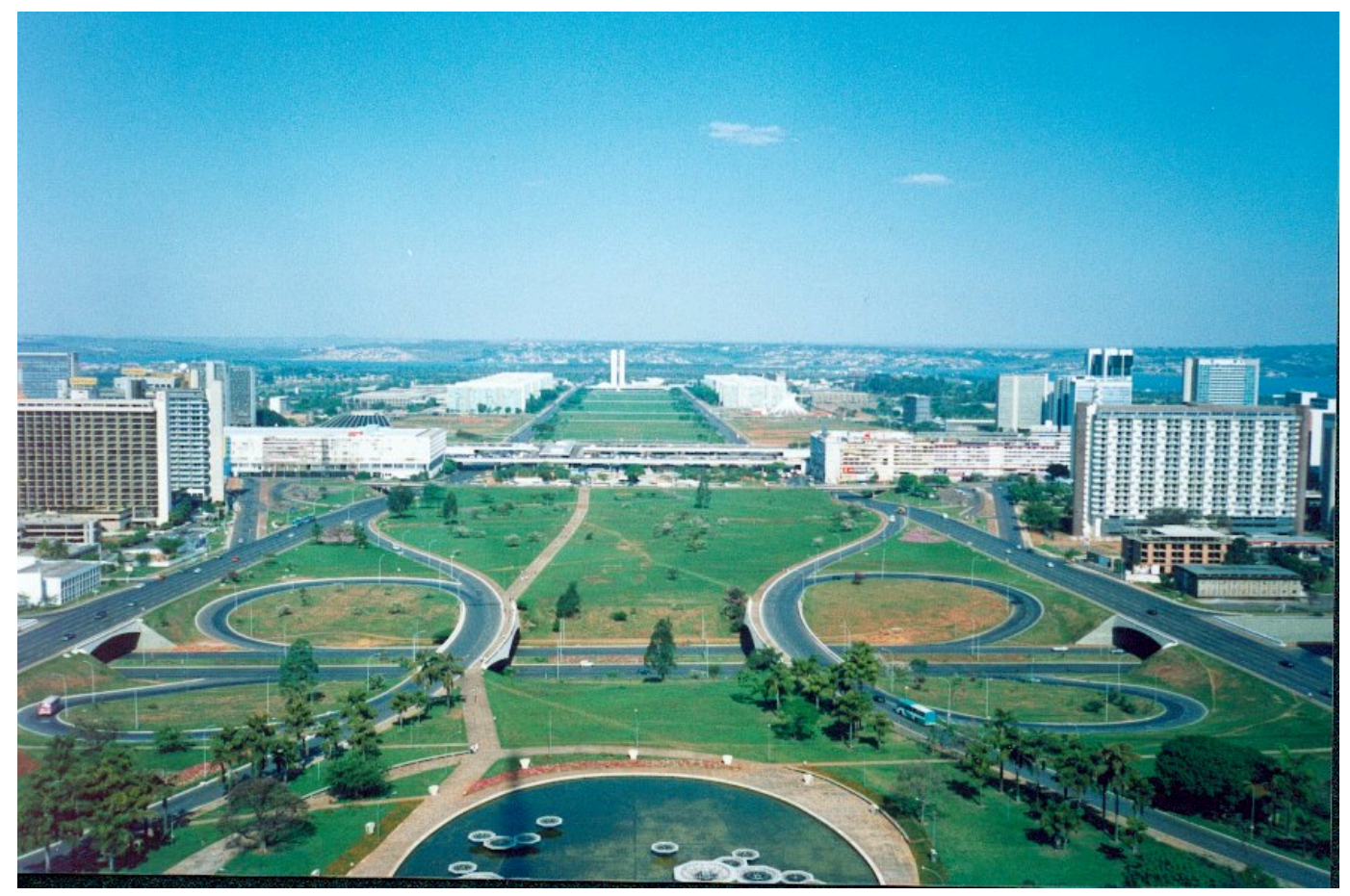

Figura 8 - Plano Piloto

Fonte: http://brazilianconsulateinseattle.com/tag/brasilia/

$\mathrm{Na} 24^{\mathrm{a}}$ sessão do Comitê do Patrimônio Mundial, em 2000, foi apresentado um relatório, do escritório local, que descrevia que a integridade da área protegida em Brasília pudesse estar ameaçada, principalmente pela pressão demográfica. O ICOMOS sugeriu a necessidade do envio da Missão de Monitoramento Reativo à cidade para examinar o estado de conservação e investigar sobre as ameaças ao ambiente do local.

Desde 1987, duas missões de acompanhamento da Unesco visitaram Brasília. Elas tinham por objetivo monitorar e avaliar o estado de conservação da cidade. A primeira visita ocorreu em 2001.

O relatório técnico da primeira Missão continha a análise da estrutura legal e institucional para a proteção e gerenciamento da cidade, assim como seu estado geral de conservação. O relatório ainda recomendava, entre outras medidas, a elaboração de um plano diretor para a área protegida a ser elaborado e adotado para garantir completamente a preservação dos valores da cidade. Sendo que os principais problemas apontados pela missão foram a pressão urbana sobre a área tombada e a falta de coordenação institucional para implantação de ações de preservação. 
Em 2003, em sua $27^{\mathrm{a}}$ sessão, o Comitê do Patrimônio Mundial continua com a recomendação para o desenvolvimento e a implementação de um plano diretor e o envolvimento de todos os níveis relevantes de autoridades, profissionais e organizações de diferentes setores da sociedade no processo contínuo de proteção e gestão da cidade. A solicitação para elaboração do plano diretor é realizada também na $28^{\mathrm{a}}$ sessão (2004). Nesse mesmo ano, a Unesco encoraja uma cooperação contínua e reforçada entre o Iphan e o GDF para atuarem no sentido de protegerem a área tombada.

Observamos que a partir dessas recomendações, o governo do Distrito Federal começa a atuar para garantir a manutenção do título de Patrimônio Cultural da Humanidade. A aprovação do PDOT e, posteriormente, o empenho para a elaboração do PPCUB são ações primordiais tomadas pelo governo local, pois esses dois documentos estão entre os elementos mais significativos para a preservação da área inscrita na Lista do Patrimônio Mundial, como também na valorização do patrimônio cultural localizado nela.

\subsubsection{O PDOT}

O plano diretor é um instrumento obrigatório pela Constituição Brasileira para cidades com população superior a 20.000 habitantes. A Lei Orgânica do Distrito Federal também define instrumentos de uso e ocupação territorial, entre eles o Plano Diretor de Ordenamento Territorial do Distrito Federal ${ }^{36}$.

O Plano de Ordenamento Territorial do Distrito Federal, o PDOT, é um instrumento legal onde são definidas as regras básicas de uso e ocupação do solo, por categoria de uso, como também critérios de controle do uso e da ocupação territoriais, mediante estruturação das instituições governamentais, onde seja contemplada a participação popular. Em 2009, o PDOT foi aprovado pela Lei Complementar $n^{0}$ 803/2009. Ainda que a legislação federal e a LODF definam o Poder Executivo como responsável pelo processo de elaboração, alteração e revisão do plano diretor há um condicionamento à participação popular nesse processo, pois trata-se de um projeto de interesse social. Porém, isso não foi observado na elaboração do PDOT, pelo pequeno número de audiências públicas para discussão do projeto (três no total!).

\footnotetext{
${ }^{36}$ A Lei Orgânica do Distrito Federal também previa a elaboração de Planos Diretores Locais. Neles, seriam definidas as diretrizes para cada aglomeração urbana, onde as questões de uso e ocupação do solo teriam maior detalhamento. Porém, esses planos foram excluídos pelo Projeto de Alteração da Lei Orgânica (PELO 13/2007), pelo governador José Roberto Arruda.
} 
Podemos dizer que o resultado alcançado com o PDOT não refletiu efetivamente o real interesse público, como desdobramento de um processo de debate entre as instituições governamentais e a população. A elaboração e revisão do Plano deveriam ser resultado de um pacto social, possibilitando, dessa forma, a origem de um processo participativo na gestão da cidade. Desse modo, podemos conjecturar que não há gestão compartilhada, nesse processo, entre poder público e sociedade civil, tomba-se um bem politicamente.

Em um processo permanente de troca de informações e de deliberações conjuntas, entre o poder público e a sociedade, permitiria a sensibilização dessa última sobre as questões da cidade. No Distrito Federal, o fato de conter uma área tombada, a cidade, antes de tudo deve ser colocada para o uso de seus habitantes. Não defendemos que Brasília deva ser colocada numa redoma a fim de preservar suas características particulares, porém é preciso haver o equilíbrio no planejamento de seu desenvolvimento e usufruto por parte da população, como também dos visitantes que nela chegam.

Desse modo, pensar na gestão participativa é trabalhar com a inclusão, inserindo a sociedade nas tomadas de decisão e na construção de sua história. É, portanto, fazer com que aqueles que estavam à margem adotem posicionamento nas decisões que lhes dizem respeito. É contribuir para torná-los sujeitos de sua própria história. Nesse sentido, é viável fazer uma outra leitura do patrimônio, na qual ele seja um significativo representante da identidade de uma localidade, sem ignorar os diversos agentes da história. E apesar dele (o patrimônio) estar quase sempre atrelado à exploração turística, pensamos que deva ser entendido como uma aproximação entre o presente e o passado, onde é possível a reafirmação da identidade pela valorização do patrimônio cultural. Como observa Banducci Júnior (2001, p. 19):

No pensamento pós-moderno, a identidade é vista como algo móvel, sempre
em construção, que vai sendo moldado no contato com o outro e na releitura
permanente do universo circundante. O contato entre turistas e residentes,
entre a cultura do turista e a cultura do residente, desencadeia um processo
pleno de contradições, tensões e questionamentos, mas que, sincrônica ou
diacronicamente, provoca o fortalecimento da identidade e da cultura dos
indivíduos e da sociedade receptora e, muitas vezes, o fortalecimento do
próprio turista que, na alteridade, se redescobre.

Assim, a construção de elementos legais para a preservação do patrimônio cultural do Distrito Federal fez com que o poder público local atuasse no sentido de normatizar, no primeiro momento, a ocupação territorial para, em seguida, tratar da área tombada e o patrimônio nela contido. 
No PDOT está a previsão de contratos com empresas para elaboração da Lei de Uso do Solo - $\operatorname{LUOS}^{37}$ e do Plano de desenvolvimento local da área tombada de Brasília, denominado Plano de Preservação do Conjunto Urbanístico de Brasília - PPCUB. O documento técnico do PDOT estabelece que:

(...) a Emenda no 49/2007 à Lei Orgânica estabeleceu, como preconiza o Estatuto da Cidade, um plano diretor unificado para o território do DF - o Plano Diretor de Ordenamento Territorial - e um conjunto de instrumentos complementares, como a Lei de Uso e Ocupação do Solo - LUOS, o Plano de Preservação do Conjunto Urbanístico de Brasília, a Lei de Parcelamento do Solo, os Planos de Desenvolvimento Local, o Código de Edificações, o Código de Posturas, além de outros instrumentos previstos no Plano Diretor, compondo um sistema legislativo de desenvolvimento urbano e territorial." (Plano Diretor de Ordenamento Territorial do Distrito Federal - Documento Técnico - Versão Final, Nov/2009, p. 169).

E a partir da elaboração do PPCUB que Brasília terá um instrumento legal para conciliar seu desenvolvimento urbano e a preservação do conjunto urbanístico tombado.

Em 2010, na 34 ${ }^{\mathrm{a}}$ sessão do Comitê do Patrimônio Mundial, o Brasil informou sobre a aprovação da Lei que instituiu o PDOT como objeto de salvaguardar a área tombada. Além disso, informou ao Comitê que o anteprojeto do Plano de Preservação do Conjunto Urbanístico de Brasília - PPCUB, produto do PDOT, estava em elaboração. Vejamos a transcrição abaixo:

O Estado Parte informou que o principal desafio deste planejamento é definir princípios e mecanismos para salvaguardar e preservar a área composta pelo Plano Urbanístico de Brasília. A Lei Complementar no 803/2009, aprovado pelo Legislativo do Distrito Federal Legislativo, em abril de 2009 , estabelece a Zona Urbana do Conjutno Tombado - ZUCT, além de definir limites e criar diretrizes para este ZUCT. O estabelecimento de zonas tampão sob uma ferramenta de planejamento diferente, o plano de preservação Local cultural urbano; existem meios adicionais para estabelecer o uso controladas zonas urbanas para proteger a área inscrita. Além disso, o Plano de Preservação do Conjunto Urbanístico de Brasília - PPCUB foi finalizado e há um projeto para proteger áreas que contribuem para manter a linha horizontal da cidade. ${ }^{38}$ (WHC-10/34.COM/7B, p. 205). (Tradução nossa).

37 A Lei de Uso e Ocupação do Solo - LUOS indica o uso de parâmetros urbanísticos de ocupação do solo, à exceção da Unidade de Planejamento Territorial Central, que corresponde à área tombada.

${ }^{38}$ Trecho original: The State Party reported that the main challenge of this planning is to define principles and mechanisms to safeguard and preserve Brasilia's Urban Plan Compound area. The Complementary Law no. 803/2009, approved by Federal District Legislative, April 2009), establishes the Compound Urban Zone (ZUCT) in addition to defining limits and creating guidelines for this ZUCT. The establishment of buffer zones come under a different planning tool, the Urban Historical site preservation plan; there are additional means to declare controlled use urban zones to protect the inscribed area. In addition, Brasilia's Urbanistic Compound 
Porém, a Unesco, na 35ª sessão do Comitê do Patrimônio Mundial (2011), considerou que as informações fornecidas pelo Brasil ainda eram imprecisas e foi apontada a ausência de linhas claras de ação para a conservação e desenvolvimento do Conjunto Urbanístico de Brasília, o que poderia representar uma ameaça para o valor excepcional universal do sítio. Outro ponto importante ressaltado pelo Comitê foi a evidência de que as recomendações da Missão encaminhada em 2001 não teriam sido implementadas.

Assim, após examinar o relatório da $34^{\mathrm{a}}$ sessão, o Comitê: "lamenta que o Estado Parte não tenha apresentado a declaração retrospectiva de valor universal excepcional e solicita sua apresentação do Comitê de Patrimônio Mundial" ${ }^{39}$ (WHC-11/35.COM/20, p. 152) (Tradução nossa). O relatório ainda nos diz que:

Em conclusão, o Centro do Patrimônio Mundial e as organizações consultivas, observa que o recente desenvolvimento na cidade teria um impacto negativo sobre o seu valor universal excepcional e, portanto, recomenda que o Comitê do Patrimônio Mundial expresse seu interesse. Além disso, a implementação de ações importantes com a finalidade de sustentar o valor universal excepcional da propriedade foi interrompido e esses devem ser retomados o mais cedo possível. Eles consideram que a falta de informações precisas e claras das linhas de ação para a conservação e desenvolvimento, poderia representar uma ameaça para o valor universal excepcional da propriedade. Também não há evidência de que as recomendações da Missão de 2001 foram implementadas; uma missão de monitoramento reativo é, portanto, recomendada para avaliar as condições presentes na propriedade ${ }^{40}$ (WHC-11/35.COM/7B, p. 245). (Tradução nossa).

Em 2012, a Unesco com o objetivo de avaliar o estado de conservação da área inscrita na Lista do Patrimônio Mundial organizou a Missão de Monitoramento Reativo. Os consultores do organismo percorreram o Plano Piloto e ouviram autoridades do GDF, do Iphan e representantes da sociedade civil sobre as condições de preservação da capital federal.

Preservation Plan has been finalised and there is a project in place to protect areas that contribute to maintaining the horizontal line of the city.

${ }^{39}$ Trecho original: (...) regrets that the State Party did not submit the retrospective Statement of Outstanding Universal Value, and requests the State Party to submit it to the World Heritage Centre.

40 Trecho original: In conclusion, the World Heritage Centre and the Advisory Bodies note that recent developments at the property would have a negative impact on the Outstanding Universal Value of the property and hence, recommend that the World Heritage Committee express its concern. Additionally, the implementation of important actions focused on sustaining the Outstanding Universal Value of the property has been halted and these need to be continued as soon as possible. They consider that the lack of precise information and clear action lines for conservation and development, could potentially pose a threat to the Outstanding Universal Value of the property. There is also no evidence that the recommendations of the 2001 mission have been implemented; a reactive monitoring mission is therefore recommended to assess the present conditions at the property." 
Entre as prioridades da missão estavam a análise de aspectos institucionais, da legislação urbanística e de preservação (como o PDOT e o PPCUB), além do impacto de projetos e intervenções na capital federal (como a revitalização da Avenida W3, o VLT e o Projeto Orla).

Após a visita à cidade, foi elaborado novo relatório enviado ao Comitê do Patrimônio Mundial. O documento foi apreciado pelo Comitê em sua $36^{a}$ Sessão. Ao analisar as escalas do projeto original, a Missão reportou o seguinte:

- Escala residencial: o estado geral foi considerado aceitável, não sendo detectadas alterações no eixo residencial na forma de ocupação das superquadras que caracterizam esta escala. A situação das entrequadras foi alterada devido às expansões irregulares ("puxadinhos"). A missão observou o grave estado de deterioração da Avenida W3 e a alteração do uso residencial das casas geminadas.

- Escala gregária: Foi detectado que as áreas que a compõem têm um aspecto heterogêneo e têm variado ao máximo o projeto original, principalmente as variações das alturas das construções que perturbam a harmonia geral que caracteriza a cidade.

- Escala bucólica: o ponto de destaque é a pressão sobre a área referente a mudanças no uso, ocupação inadequada e perda de espaços abertos. O planejamento para o setor Noroeste é uma preocupação para manter a relação original entre o Plano Piloto e seus arredores. Outro local de ocupação irregular que chamou a atenção foi o Lago Paranoá, onde as características de um espaço aberto e natural estão em vias de ameaça. A expansão da Vila Planalto pode provocar a perda de seu caráter original.

A Missão considerou que as alterações formais no projeto original, provocadas principalmente pela pressão urbana poderiam afetar o plano original da cidade. Alguns trechos do citado relatório:

Um controle mais estrito é necessário para evitar a perda de setores verdes e para dissuadir construções irregulares de estruturas de forma desordenada e precária $^{41}$ (WHC-12/36.COM/7B.Add, p. 195). (Tradução nossa).

A preocupação da Unesco com a descaracerização do conjunto urbanístico é claramente anunciada no trecho acima. O respeito às escalas do projeto de Lucio Costa, segundo o relatório, está sendo ignorado na área tombada quando projetos habitacionais e

${ }^{41}$ Trecho original: Stricter control is needed to prevent further loss of green sectors and to deter irregular construction of structures in a disorderly and precarious fashion. 
construções comerciais são implantados desobedencendo qualquer padrão para sua manuntenção. A área verde também sofre essa ameaça, quando percebe-se que os espaços destinado ao lazer da população dividem espaço com empreendimentos particulares. Outra fonte dessa pressão exercida sobre Brasília também advém da utilização da cidade para usufruto de serviços dos moradores de outras regiões do Distrito Federal. A necessidade de garantir acesso à cidade pode também representar uma nova ameaça à perda do título, devido às possíveis adaptações no projeto original para atendê-la.

A Missão considerou que as alterações formais no projeto original, o controle do uso e o controle do desenvolvimento no cenário precisa ser melhor gerido e planejado, a fim de evitar a perda de autenticidade. Em termos de integridade, é fundamental que disposições legais precisas sejam feitas para garantir que as pressões derivadas da especulação de terras não ponham em risco as condições que justificaram a inscrição na Lista do Património Mundial ${ }^{42}$ (WHC-12/36.COM/7B.Add, p. 197). (Tradução nossa).

As observações da Unesco quanto à preservação das escalas do projeto original da cidade demonstram a preocupação da descaracterização da cidade em face ao seu desenvolvimento descoordenado. Mas o organismo também apreende um descontentamento da sociedade quanto à elaboração do PL que dará corpo ao PPCUB: "Embora duas audiências públicas tenham sido realizadas, a Missão observou expressões de insatisfação da sociedade civil a respeito dos métodos de consulta"43 (WHC-12/36.COM/7B.Add, p. 194). (Tradução nossa).

A participação popular na elaboração do PPCUB não é apenas uma recomendação da Unesco, mas tornou-se uma reivindicação da sociedade brasiliense na gestão da área tombada. O desenvolvimento da participação engajada e efetiva da comunidade residente para, inclusive, atuar como norteadora de ações que apontem para a preservação de seu patrimônio cultural pode apontar o que é significativo para ela, em termos de lugares, memórias e histórias. O PPCUB poderá representar não apenas uma legislação norteadora para o desenvolvimento urbano da cidade, como ele poderá ser ainda mais um elemento para a preservação e valorização do patrimônio que Brasília representa, como também daqueles bens

\footnotetext{
${ }^{42}$ Trecho original: The mission considered that formal alterations in original design, control of use and control of development in the setting need to be better managed and planned for in order to prevent loss of authenticity. In terms of integrity, it is critical that accurate legal provisions are made to ensure that pressures derived from land speculation do not jeopardize the conditions that warranted inscription on the World Heritage List.

43 Trecho original: Although two public hearings have taken place, the mission noted expressions of insatisfaction from civil society regarding the consultation methods.
} 
localizados em sua área tombada, possibilitando, por consequência, o incremento do turismo local.

A Missão de Monitoramento Reativo de 2012, a fim de que a cidade evitasse a perda de autenticidade e, após reconhecer a falta de um plano diretor de preservação da área tombada, também recomendava seis ações prioritárias, entre elas destacamos:

1. Manter que as características originais, a concepção e as escalas do projeto de Lucio Costa que asseguraram a inscrição de Brasília na Lista do Patrimônio Mundial estejam contempladas no PPCUB;

2. Estabelecer um sistema de gestão eficaz para coordenar o processo e reforçar a cooperação em matéria de conservação de tomada de decisão e gestão da propriedade através da definição de um quadro jurídico, a criação de uma estrutura de gestão central para o bem do Patrimônio Mundial, estabelecendo os papéis e responsabilidades das autoridades administrativas envolvidas e a alocação de recursos necessários para o seu funcionamento adequado no local, regional e nacional.

Uma estrutura administrativa consistente, assim como uma legislação específica voltada para a gestão do patrimônio cultural do Distrito Federal é muito importante para que ações futuras sejam eficazes no sentido da preservação e valorização desse patrimônio.

Vimos que a elaboração do PPCUB não está afeta apenas ao Conjunto Urbanístico de Brasília, mas também contempla os bens tombados situados nessa área, visando sua proteção, recuperação, valorização e aproveitamento das potencialidades do patrimônio cultural do Distrito Federal.

\subsubsection{O PPCUB}

O Plano de Preservação do Conjunto Urbanístico de Brasília - PPCUB consiste na proposição final do Plano de Preservação de Brasília, como instrumento básico de planejamento e controle da evolução físico-espacial do Conjunto Urbanístico de Brasília, sendo um regulador da ordenação urbanística e de preservação do conjunto tombado. Formulado como Projeto de Lei Complementar, tem como sua área de abrangência as Regiões Administrativas do Plano Piloto (RA I), do Cruzeiro (RA XI), da Candangolândia (RA XIX) e do Sudoeste/Octogonal (RA XXII), somando 487,73 km² (Mapa 1). Integra esse território a área tombada do Conjunto Urbanístico de Brasília, com superfície de 112,25 Km². 
Mapa 1 - Área de abrangência do Plano de Preservação do Conjunto Urbanístico de Brasília

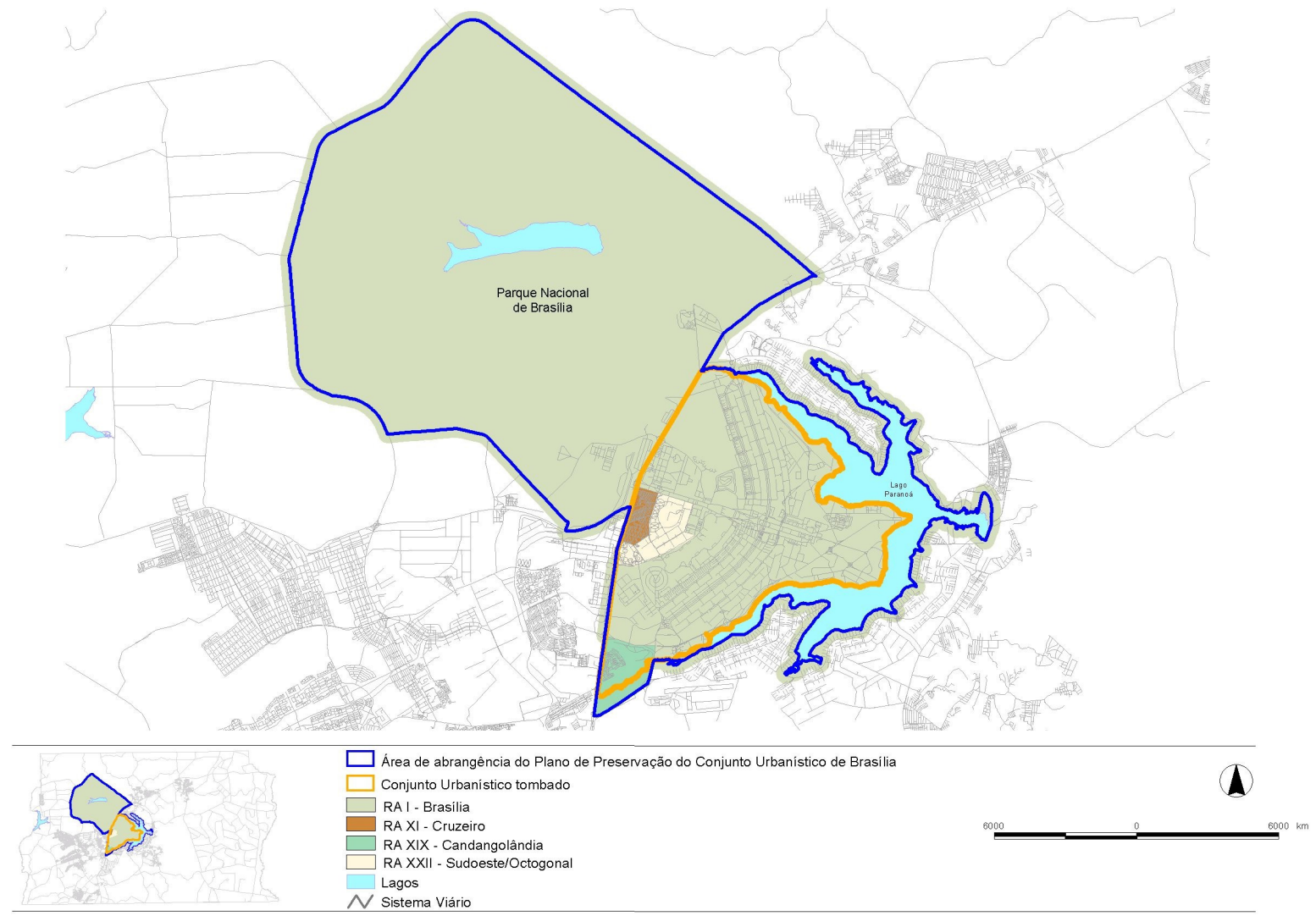

O PPCUB foi elaborado com a coordenação da antiga Secretaria de Habitação, Regularização e Desenvolvimento Urbano - Sedhab (atualmente Segeth). Essa Secretaria é responsável por sua elaboração, acompanhamento e revisão. Para essa discussão, estão se reunindo desde 2009, representantes do governo local e da sociedade civil ${ }^{44}$ para a confecção, como resultado final, a elaboração de um projeto de lei com todas as diretrizes para o desenvolvimento da cidade na área tombada. Nossa análise recaiu sobre os dois projetos de lei complementar, pois assim foi possível identificar o tratamento dado ao tema, em especial ao patrimônio cultural e o incentivo ao turismo na cidade, e as alterações propostas na segunda versão do documento.

O Plano (PLC $\mathrm{n}^{\circ}$ 52/2012) foi aprovado pelo Conselho de Planejamento Territorial do Distrito Federal - Conplan e, em outubro de 2012, enviado à Câmara Legislativa do Distrito Federal - CLDF. Porém, não teve sua aprovação no Legislativo, pois além de manifestações

\footnotetext{
${ }^{44}$ A discussão com representantes da sociedade civil é uma intenção de aumentar o grupo em torno da discussão do projeto de lei no qual resultará o PPCUB. Entre eles estão: Associação Civil Rodas da Paz, Associação das Empresas do Mercado Imobiliário do DF, Urbanistas por Brasília, Instituto dos Arquitetos do Brasil - IAB, Associação de Moradores no DF - ÚNICA/DF, Conselho de Arquitetura e Urbanismo do DF - CAU/DF, Conselho Regional de Engenharia e Agronomia - CREA/DF, Conselho Regional de Engenharia e Agronomia CREA/DF, entre outros.
} 
da sociedade civil, o Iphan também solicitou à época que a votação fosse adiada para a revisão de alguns pontos. Entre eles, o Plano previa a construção da nova quadra no Setor Sudoeste, possibilidade de construção de mais hotéis na orla do Lago Paranoá, além de um projeto hoteleiro para a 901 Norte. Sendo esses últimos uma das poucas referências diretas ao incremento do turismo local pelo PPCUB.

Em 2013, uma nova versão do PPCUB foi enviada novamente à CLDF. O PLC n ${ }^{\circ}$ 78/2013 apresentava alterações na proposta original, abrangendo a área tombada. O texto setoriza melhor as diretrizes para o uso do território, mas as ações voltadas para o fomento ao turismo ainda permanecem tímidas.

\subsection{PPCUB, patrimônio cultural e turismo}

Para atender às recomendações da Unesco, o reconhecimento de que trata da valorização do patrimônio cultural de Brasília, em especial seu conjunto urbanístico, não pode ser dissociado do desenvolvimento urbano da cidade, ou seja, desenvolvimento e respeito aos bens culturais devem estar em consonância.

A cidade ainda permanece inacabada, à medida que aparecem demandas da população que não foram contempladas no projeto original. O documento Brasília Revisitada (ANEXO II), elaborado por Lucio Costa, nos traz as características fundamentais a serem preservadas para que a cidade consiga harmonizar seu crescimento, "assegurando a permanência do testemunho da proposta original" (COSTA, 1987), preservando seu conceito urbanístico. É esse documento que deve ser o norteador do PPCUB. Assim, o processo de apropriação do território da cidade pela sociedade é de fundamental importância à medida que ele serve tanto a seus moradores quanto aqueles que se utilizam dela para o trabalho, lazer e turismo.

Dessa forma, o PPCUB se apresenta como o principal instrumento para o planejamento, preservação e gestão da área protegida e do patrimônio cultural, como também para coordenar as medidas e os agentes envolvidos no desenvolvimento urbano de Brasília.

Em suas Disposições Gerais, o PPCUB é definido como "o instrumento central da política de preservação, de planejamento e de gestão do Conjunto Urbanístico de Brasília, cujos programas, projetos e ações devem ser incorporados aos demais instrumentos de planejamento do Distrito Federal." (PLC nº 78/2013. Art. 1º, Caput). 
Nos projetos de lei complementar de instituição do PPCUB, vemos o esforço no sentido da conservação da condição de Brasília como Patrimônio Mundial da Humanidade. A preservação, manutenção e valorização do Conjunto Urbanístico de Brasília, na salvaguarda de suas quatro escalas está presente em todo o texto dos PLCs.

A valorização do patrimônio cultural já constituído, localizado no Conjunto Urbano de Brasília, também está contemplada, representando ponto de destaque para a atuação do governo local.

O PLC no 52/2012 nos traz, como um dos pontos relevantes, a atribuição de obrigações para os órgãos distritais no que diz respeito ao planejamento, gestão, preservação e fiscalização do patrimônio local, sendo eles: a Segeth, a SeCult, a Agefis e as Administrações Regionais que compõem a área tombada. Dentre essas atribuições, o Plano define algumas responsabilidades específicas, a saber:

- Segeth - A Segeth é responsável pelo planejamento, gestão e preservação do Conjunto Urbanístico de Brasília. É de sua responsabilidade também a elaboração, acompanhamento e revisão do PPCUB.

- Secretaria de Cultura - Cabe à esta Secretaria, com a colaboração de outras instituições (públicas e privadas), desenvolver a preservação dos bens culturais, de forma integrada, por meio da implementação de um programa de educação patrimonial e de "programa para integração das ações de preservação do patrimônio material, arquitetônico, urbanístico e paisagístico de Brasília, promovendo a catalogação e inventário dos bens com valor patrimonial" (art. 157, inciso II - PLC 52/2012);

Em sua segunda versão, no PLC n ${ }^{\circ}$ 78/2013, essas atribuições não estão nominalmente definidas. Os órgãos reguladores e responsáveis pela preservação e promoção do patrimônio cultural aparecem no documento como "unidade de preservação histórica, artística e cultural", "órgão de gestão do patrimônio cultural do DF" ou "órgão responsável pela coordenação das Administrações Regionais".

A falta de indicação objetiva dos órgãos responsáveis por essas atividades pode deixar de ocasionar uma mudança na gestão do patrimônio do Distrito Federal. É preciso que haja a integração governamental, tanto em nível distrital como entre o GDF e a esfera federal, objetivando um melhor acompanhamento da conservação e valorização desse patrimônio, bem como as atribuições legais específicas para a atuação desses órgãos. 
Quanto ao patrimônio cultural edificado, como vimos, é de responsabilidade da Secretaria de Cultura sua valorização e promoção. Entre um dos objetivos gerais do Plano está a identificação e valorização de bens culturais que sejam representativos da época da implantação da capital. Esse artigo está presente nos dois PLCs e orienta novos tombamentos e adoção de medidas de proteção.

Quanto ao turismo, observamos que o PPCUB nos diz da importância do "reconhecimento da preservação como fenômeno integrado ao processo de desenvolvimento urbano e como propulsor do desenvolvimento turístico" (art. $3^{\circ}$, inciso IV - PLC n ${ }^{\circ} 52 / 2012$ ). No capítulo que versa sobre suas diretrizes gerais, temos que nos dois documentos está contemplado o "fomento ao desenvolvimento de projetos turísticos, de lazer, cultura e educação à preservação do patrimônio cultural" (art. 5\%, inciso VI - PLC n ${ }^{\circ}$ 52/2012 e art. $7^{\circ}$, inciso VI - PLC n $\left.{ }^{\circ} 78 / 2013\right)$.

Mesmo dispondo que deve haver "melhoria e intensificação da articulação entre as diversas esferas político-administrativas com competência sobre o Conjunto Urbanístico de Brasília para a maior eficácia na gestão do patrimônio cultural urbano" (art. $5^{\circ}$, inciso XV PLC $n^{\circ}$ 52/2012 3 art. $7^{\circ}$, inciso XV - PLC no 78/2013) e "incentivo ao desenvolvimento de projetos turísticos, de lazer, cultura e educação à preservação do patrimônio cultural" (art. 12, inciso VII - PLC no 52/2012 e art. 14, inciso VII - PLC n ${ }^{\circ}$ 78/2013), não observamos nos documentos nenhuma referência à Secretaria de Turismo como parte dessa articulação. $O$ turismo aparece basicamente na propositura de ações genéricas, inclusive na referência à Vila Planalto e ao Lago Paranoá (Projeto Orla). O PPCUB, nas duas versões analisadas se apresenta mais como um instrumento de desenvolvimento urbano do que de preservação. As recomendações da Unesco para que fosse elaborado pelo governo local instrumentos legais para a conservação da área inscrita na Lista do Patrimônio Mundial recebeu um viés de partilha e ocupação do solo.

Como vimos, o patrimônio cultural pode e é utilizado como um recurso turístico e a análise feita nos dois documentos nos demonstra que ainda não há aprofundamento na questão do patrimônio pelo governo distrital. As recomendações genéricas no PLC n ${ }^{\circ}$ 52/2012 para a gestão do patrimônio cultural e no PLC n ${ }^{\circ}$ 78/2013 para o desenvolvimento do turismo localmente, nos fazem perceber que a chancela de patrimônio oficial parece ser suficiente para as autoridades que o turismo se estabeleça na cidade.

O turismo aparece contemplado no documento quando se faz referência à expansão do setor hoteleiro ou à ocupação da orla do Lago Paranoá. Destacamos que as duas versões do PPCUB foram elaboradas antes da realização da Copa do Mundo de Futebol de 2014, onde 
Brasília foi uma das sedes do evento. Mesmo assim, em nenhum momento houve menção à Secretaria de Turismo como parte gestora desse processo nos PLCs.

Sabemos que é impossível para a cidade manter sua imutabilidade diante das demandas populacionais, mas é preciso que haja uma gestão conciliadora para seu desenvolvimento e a preservação de seu patrimônio cultural. Nesse sentido, o desenvolvimento do turismo poderia ser apresentado como forma de incentivo à preservação do patrimônio local, à medida que ele pode proporcionar, desde que desenvolvido de forma consciente e sustentável, a valorização desse patrimônio para os moradores da cidade.

O que o PPCUB também faz é trazer a orientação para firmar parceria entre o governo federal e distrital para a gestão da área tombada, acatando a orientação da Unesco, após sua segunda Missão de Monitoramento Reativo, em $2012^{45}$.

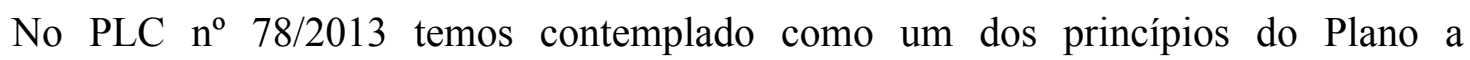
"articulação entre os governos distrital e federal para o planejamento e gestão do conjunto urbano tombado" (PLC n ${ }^{\circ} 78 / 2013$, artigo 5 $5^{\circ}$, inciso VII). É importante que essa articulação se estabeleça, pois além do título de Patrimônio Cultural da Humanidade, Brasília possui as chancelas de Patrimônio Cultural do Brasil e Patrimônio Cultural do Distrito Federal. A atuação de duas esferas governamentais para a gestão dessa área deverá estimular o desenvolvimento de projetos, programas e normas de interesse comum à preservação do Conjunto Urbanístico, além de difundi-lo como patrimônio cultural. Agindo de forma unificada, o poder público pode implementar ações no sentido de desenvolver o turismo por meio da promoção desse patrimônio, que contempla outros bens tombados em sua área.

\subsection{O Conjunto Urbanístico de Brasília - uma tentativa pelo PPCUB}

No caso do Conjunto Urbanístico de Brasília, a gestão da área tombada está a cargo do Iphan e da Secretaria de Gestão do Território e Habitação do Distrito Federal - Segeth.

Desde a obtenção do título de Patrimônio Cultural da Humanidade, o tombamento tornou-se um via de mão dupla para Brasília, onde a chancela concedida para a Unesco tornou-se símbolo de status e privilégio (inclusive para o incremento do turismo), mas ao mesmo tempo exige ações para a preservação e valorização desse bem.

\footnotetext{
${ }^{45}$ Em março de 2015, ocorreu a assinatura do Acordo de Cooperação Técnica para a gestão compartilhada do Conjunto Urbanístico de Brasília. Os órgãos signatários do acordo são a Secretaria de Gestão do Território e Habitação - Segeth/GDF e o Iphan.
} 
O Conjunto Urbanístico de Brasília é o exemplo de como o peso do título de patrimônio cultural pode ser oneroso ao Estado. Analisando as recomendações dadas pela Unesco, vimos que desde a inscrição de Brasília, foram exigidas dos órgãos governamentais brasileiros medidas para a conservação das características que justificaram o título. As missões de monitoramento enviadas pela Unesco a Brasília também surtiram efeito quanto a impelir o poder público a tomar as providências nesse sentido. Primeiro, a elaboração de um plano diretor para a cidade que, mesmo previsto na Constituição Brasileira e na LODF, só teve sua publicação 2009. Mesmo com o PDOT aprovado, a Unesco ainda exigia maiores providências para a preservação do Conjunto Urbanístico, devido às ameaças causadas pelo inchaço populacional e a expansão imobiliária. Em análise feita aos relatórios do Comitê do Patrimônio Mundial, temos que além de elementos legais para a proteção da área tombada, havia a recomendação para a criação de uma aliança entre os governos federal e distrital para atuarem articuladamente para a preservação de Brasília (o que só ocorreu em 2015).

A demora dos órgãos governamentais em atender às recomendações do organismo internacional não se deve apenas à inércia do poder público. Ela é causada também pelas pressões sofridas para que fossem aprovadas intervenções na área tombada, principalmente pelo setor imobiliário, o que retardaram a conclusão do Plano.

Assim, a partir do PDOT foi proposta a elaboração do PPCUB, que será o Plano que cuidará do conjunto urbanístico da cidade, regulamentando sua ocupação e uso. Apesar de não estar finalizado, o PPCUB representa o principal instrumento para a preservação do patrimônio cultural de Brasília. Além de tratar do conjunto urbanístico da cidade, ele apresenta também diretrizes para a valorização do patrimônio cultural edificado.

Observamos que desde 2009, a discussão em torno do PPCUB se apresenta distinta da ocorrida para a elaboração do PDOT. Sendo que no primeiro caso, está contemplada a participação de diversas instituições governamentais e da sociedade civil. O plano foi encaminhado duas vezes à CLDF. Com a não aprovação do PLC 52/2012 pela CLDF e a declaração de nulidade das decisões do Conplan, o Governo do Distrito Federal, encaminhou novamente o Plano para apreciação da casa legislativa. O PLC 78/2013 continha várias alterações, mas todas pertinentes à ocupação da área tombada. Não houve nenhuma modificação nas ações do poder público quanto à valorização e promoção do patrimônio cultural da cidade. Mesmo ainda sem sua implementação, o PPCUB representa uma maneira de atuação popular nas ações decisórias pertinentes ao patrimônio coletivo. 
Essa concepção de patrimônio fica visível quando percebemos a mobilização em torno do patrimônio cultural da cidade. Não apenas nos bens edificados tombados, como também do conjunto urbanístico. O teor simbólico atribuído ao patrimônio cultural se funde à sua materialidade. Vimos a refuncionalização do patrimônio que está além dos limites impostos pelo tombamento, não só em sua ambiência (entorno), mas em seu caráter simbólico, representativo de uma memória viva.

A preservação do patrimônio se apresenta oneroso em todas as instâncias, mas ao refletir valores de uma identidade territorial, permite sua apropriação sensível por parte daqueles que o vivencia. Como afirma Faria (2009), "o verdadeiro patrimônio da cidade não é o patrimônio físico, mas sua história" (FARIA, 2009, p. 263).

Assim como o comportamento social contemporâneo, o turismo vem de desenvolvendo com a valorização da cultura regional, onde as particularidades locais são apreciadas como elementos de diversificação e de exclusividade. Esse sentimento de acessar a individualidade de um grupo pode se dar por meio do contato com seus bens culturais.

Nessa perspectiva, o turismo pode ser encarado como elemento para o usufruto e valorização do patrimônio cultural, não apenas para aqueles que se deslocam, como para as pessoas transitam pelas cidades. O crescimento desordenado de Brasília fez surgir espaços de multiplicidade cultural, um terreno heterogêneo onde é apresentada uma variedade de valores culturais, tornando-se um espaço de diversidade. Porém, a cidade é ainda referenciada pelo seu aspecto monumental, por aquela estética estabelecida pela arquitetura modernista. E é ela, indubitavelmente, que provoca ainda a motivação para atrair visitantes.

Não há como não considerar o turismo como fato social e econômico reconhecido. Isso é evidente. Também não há como evitá-lo, pois “o turismo assemelha-se a um nevoeiro, ele se insinua por todos os cantos" (KRIPPENDORF, 2001, p. 80). Diante disso, por que não relacioná-lo à valorização do patrimônio cultural local?

No caso do Distrito Federal, como já destacamos, os bens integrantes da lista de tombo passam por dificuldades para a sua conservação e manutenção. A atuação governamental se estabeleceu sem planejamento, onde observamos a falta de orçamento necessário, ausência de recursos humanos suficientes e capacitados e clareza na definição das atribuições dos órgãos envolvidos na gestão do patrimônio cultural. O turismo local ainda é carente de diretrizes para potencializar seu desenvolvimento, assim como também não notamos a articulação entre as 
unidades governamentais para uma atuação compartilhada que proporcione a valorização do patrimônio cultural pelo turismo.

O caso do Distrito Federal, no que se refere à gestão do patrimônio, não se distancia do restante do Brasil. Conforme Barreto (2000) a inexistência de políticas públicas eficientes acarreta em tomada de decisões equivocadas, tanto do setor público quanto do privado, na ausência de atuação daquele, tendo um aproveitamento insuficiente dos benefícios que o turismo pode proporcionar.

Assim, a elaboração do PPCUB representa para Brasília e seu patrimônio cultural a consolidação de um instrumento legal para sua preservação e valorização. Ele pode ser o instrumento exigido pela Unesco para a manutenção do título de Patrimônio Cultural da Humanidade, mas pode ser o norteador para o desenvolvimento sustentável do sítio tombado. A valorização do patrimônio cultural também é elemento de construção desse documento. $\mathrm{O}$ reconhecimento oficial da relação possível a ser estabelecida entre o patrimônio e o incremento do turismo local deve ser apontada como uma nova forma de construção de instrumentos legais que viabilizem ações das instituições governamentais e demais organismos que atuam na preservação e valorização do patrimônio cultural. 


\section{CONSIDERAÇÕES FINAIS}

Como vimos, a responsabilidade, a conservação e manutenção dos monumentos e edifícios do Distrito Federal cabem ao Iphan e à Secretaria de Cultura, por meio da Suphac. A valorização do patrimônio cultural passa por essas duas esferas também. Tal valorização pode constituir uma alternativa para o desenvolvimento do turismo local. Observamos na capital a propagação do turismo cívico e arquitetônico como produtos das empresas turísticas, como do governo local. Porém, a ineficiência de articulação entre os diversos setores não perenizam as ações nesse sentido.

No que se refere à relação desse patrimônio com o desenvolvimento do turismo, a dinâmica do processo de tombamento no Distrito Federal é cambiante, quando tem-se em seu inventário o primeiro núcleo urbano contemporâneo inscrito dos bens de valor universal, a outra parte dos bens tombados ainda não são tão representativos para o turismo local. A obra de Niemeyer atrai visitantes do mundo inteiro, mas percebe-se uma desarticulação entre o órgão responsável pela preservação e gestão desses bens e outros órgãos que regulam a atividade turística local. Mesmo com um patrimônio tão relevante, de reconhecimento internacional, não foi ainda firmada a gestão articulada que pudesse ter a valorização do patrimônio cultural como recurso para o turismo. As ações são pontuais e, muitas vezes interrompidas nas sucessões governamentais, observando-se que o planejamento geralmente desenvolve-se para curto e médio prazo.

Em última análise, não podemos desconsiderar o sujeito nesse contexto. O patrimônio é, como vimos, um elemento de atratividade para o mercado turístico, mas ele antes de tudo deve ser símbolo da identidade de um lugar.

Em sua concepção original, Brasília deveria coincidir com o Plano Piloto, mas com a criação de cidades-satélites para obrigar os operários que vieram atuar na construção civil e permaneceram por aqui, a cidade teve um desvio de seu modelo primário. Diferente do projeto social que a nova capital representava como a vitrine da modernidade brasileira, os pioneiros, ao serem abrigados em cidades distantes do centro político-administrativo da capital tiveram que se organizar em novos espaços, desenvolvendo laços e acumulando experiências sociais. E ao construírem novas histórias, formam o que Nunes (2005) chama de patrimônios subterrâneos, onde valores culturais e pontos de vista das pessoas comuns, 
daquelas que não pertencem às elites, são sistematicamente ignorados na gestão do patrimônio da cidade.

Os discursos oficiais adotam a postura que a democratização da cultura está refletida em suas ações, dando assim, a legitimidade para a constituição do patrimônio oficial coletivo. Porém, no caso do patrimônio cultural do Distrito Federal, ele continua refletindo a exclusão das classes populares. A atuação do Iphan no processo de tombamento no DF segue a orientação histórica do órgão ao privilegiar as construções monumentais. Isso demonstra que a ausência das pessoas comuns nos debates que tratam da questão da preservação e gestão patrimonial provocam o descompasso das superestruturas de políticas culturais em relação à realidade global da sociedade brasileira, diz Ortiz (2012). Na esfera distrital pode-se observar que a inclusão de representação cultural das classes periféricas na constituição do patrimônio cultural local, como é o caso da Vila Planalto, a Caixa d'água da Ceilândia e da Igreja São Geraldo, no Paranoá. A importância da refletividade dos vários grupos que compõem a sociedade na constituição do patrimônio cultural existe porque ele expressa uma conexão entre aqueles que o compartilham.

O PPCUB, que será o instrumento norteador da ocupação e gestão do território que abrange a área tombada e, por consequência para sua conservação, traz em seu texto apontamentos quanto à preservação do patrimônio cultural de Brasília. Não se refere apenas ao Conjunto Urbanístico, mas preconiza a valorização do patrimônio edificado na capital. A articulação entre os governos federal e distrital para tanto é uma das exigências da Unesco para a manutenção do título, mas o documento também prevê a participação popular nesse processo.

Portanto, não podemos desconsiderar o sujeito nesse contexto. O patrimônio é, como vimos, um elemento de atratividade para o mercado turístico, mas ele antes de tudo deve ser símbolo da identidade de um lugar. A apropriação e participação dos diversos grupos da sociedade civil no processo de valorização desse patrimônio se apresentam como uma forma de se conseguir a representação da identidade de um grupo na legitimação cultural.

Citando Choay, é preciso considerar a diferença entre querer e saber "tombar" um bem e entre saber conservá-lo e restaurá-lo, sendo empregados tipos diferentes de conhecimento nos dois casos. Aplicando à realidade do Distrito Federal, não basta ter mecanismos legítimos e um aparato administrativo se não houver a consciência do que representa o processo de tombamento. O usufruto e o acesso a um bem cultural pela população e, por conseguinte pelos 
turistas, dependerá de um plano e ações contínuos de preservação, salvaguarda e promoção desse bem.

As ações políticas que versam sobre o patrimônio cultural, devem estar voltadas para a atuação, para a valorização e para a salvaguarda dos bens culturais, entendendo a memória e a história como direitos de toda a população. As políticas culturais devem contemplar a preservação e a valorização da herança cultural, para que as gerações futuras tenham a possibilidade de reconhecer e refletir sobre suas referências de identidade. Porém, vimos que os mecanismos legais de valorização e promoção do patrimônio cultural local (existentes ou em fase de elaboração) ainda não resultaram em atuações relevantes nesse contexto. As ações voltadas para a gestão e preservação do patrimônio cultural do Distrito Federal são genéricas e, pela pouca articulação entre os órgãos envolvidos (na esfera distrital e federal) deixam de atuarem conjuntamente para aplicação de programas contínuos para a valorização desse patrimônio.

A construção de um universo simbólico a partir do tombamento do patrimônio edificado está legitimada pela ideia de preservar um conjunto de elementos de relevância histórica e cultural, reflexo da memória de uma localidade. Portanto, ações governamentais que contemplem a sensibilização da sociedade quanto ao seu acervo são necessárias na valorização do patrimônio cultural. Como afirma Costa (2011, p. 40), "há de se trabalhar as cidades não somente no plano de sua materialidade, mas também no da subjetividade, simultaneamente; quer dizer, a sociedade não só produz, historicamente, formas espaciais, condições de sobrevivência, mas também reproduz, no seu imaginário, as representações simbólicas da cidade." 


\section{REFERÊNCIAS}

BANDUCCI Jr., Álvaro, BARRETO, Margarita (orgs). Turismo e identidade local: uma visão antropológica. Campinas, SP: Papirus, 2001. (Coleção Turismo).

BARRETO, Margarita. Turismo e legado cultural: As possibilidades do planejamento. Campinas, SP: Papirus, 2000. (Coleção Turismo).

BARROSO, Eloísa Pereira. Brasília: as controvérsias da utopia modernista na cidade das palavras. 236f. Tese (Doutorado em Sociologia) Universidade de Brasília, Brasília, 2008.

BAUMANN, Zygmunt. Identidade: entrevista a Benedetto Vecchi. Tradução Carlos Alberto Medeiros. Rio de Janeiro: Jorge Zahar Ed., 2005.

BRASIL. Decreto-Lei $\mathrm{n}^{\circ}$ 25, de 30 de novembro de 1937. Organiza a proteção do patrimônio histórico e artístico nacional. Diário Oficial da União. Brasília, DF, novembro de 1937. Disponível em: <http://www.iphan.gov.br/ http://portal.iphan.gov.br/uploads/legislacao/Decreto_Lei_n_25_de_30_de_novembro_de_19 37 pdf $>$ Acesso em: 20 de fevereiro de 2014.

BRASIL. Câmara dos Deputados. Legislação sobre o patrimônio cultural. 2. ed. Brasília: Câmara dos Deputados, Edições Câmara, 2013. (Série legislação, n. 92).

CANCLINI, Néstor Garcia. Culturas híbridas: estratégias para entrar e sair da Modernidade. $4^{\text {a }}$ edição, São Paulo: Editora da Universidade de São Paulo, 2003 (Ensaios Latino-americanos I)

CANCLINI, Néstor Garcia."Culturas Visuais: entre a Arte e o Patrimônio". In: A Sociedade sem Relato: Antropologia e Estética da Iminência. Tradução Maria Paula Gurgel Ribeiro. São Paulo: Editora da Universidade de São Paulo, 2012. pp. 65-98.

CASTRO, Iná Elias de. "Paisagem e turismo: de estética, nostalgia e política". In: Yázigi, Eduardo (org.). Turismo e paisagem. São Paulo: Contexto, 2002, pp. 121-140 (Turismo Contexto).

CELLARD, André. A análise documental. In: POUPART, J. (Org.). A pesquisa qualitativa: enfoques epidemiológicos e metodológicos. Petrópolis: Vozes, 2008. p. 295-316.

CHOAY, Françoise. A alegoria do patrimônio. Tradução de Luciano Vieira Machado. $4^{\mathrm{a}}$ ed. São Paulo: Estação Liberdade: UNESP, 2006. 288p. : il.

COMPANHIA DE PLANEJAMENTO DO DISTRITO FEDERAL. Disponível em: www.codeplan.df.gov.br, acesso em 15/10/2013.

COSTA, Lucio. Brasília Revisitada 1985-87: Complementação, Preservação, Adensamento e Expansão Urbana. Brasília, 1987.

COSTA, E. B \& SCARLATO, F. C. "Patrimônio da Humanidade: universalismo de um apoderamento territorial soberano." In: COSTA, E. B; BRUSADIN, L.; PIRES, M. (orgs.). Valor patrimonial e turismo: limiar entre história, território e poder. São Paulo: Outras Expressões, 2012. p. 103-136 
COSTA, Everaldo. B. Totalidade urbana e totalidade-mundo - as cidades coloniais barrocas face à patrimonialização global. 445f. Tese (Doutorado em Geografia) FFLCH-USP, São Paulo, 2011.

DISTRITO FEDERAL. Decreto $n^{0} 34.587$, de 22 de agosto de 2013. Extingue e cria cargos da Secretaria de Estado de Cultura do Distrito Federal que especifica e dá outras providências. Diário Oficial do Distrito Federal $n^{\circ} 175$, de 23 de agosto de 2013. p. 1.

DISTRITO FEDERAL. Decreto $\mathrm{n}^{\mathrm{o}}$ 28.238, de 27 de agosto de 2007. Dispõe sobre o tombamento provisório do Centro de Ensino Médio EIT e o Centro Cultural Teatro da Praça. Diário Oficial do Distrito Federal no 166, de 28 de agosto de 2007. p. 3.

DISTRITO DEDERAL. Decreto $\mathrm{n}^{\circ}$ 25.849, 17 de maio de 2005.

DISTRITO FEDERAL. Decreto n 10.829, de 14 de outubro de 1987. (Lei Santiago Dantas).

DISTRITO FEDERAL. http://www.brasiliapatrimoniodahumanidade.df.gov.br/. Acesso em 9/02/2015

DISTRITO FEDERAL. http://www.segeth.df.gov.br/sala-de-imprensa/noticias/item/3047patrim $\% \mathrm{C} 3 \% \mathrm{~B} 4$ nio-hist $\% \mathrm{C} 3 \% \mathrm{~B} 3$ rico-gdf-entrega-igreja-restaurada-com-dinheiro-dofundurb.html. Acesso em 05/04/2015.

DISTRITO FEDERAL. Pesquisa sobre o tombamento de Brasilia. 14 de dezembro de 2012. Companhia de Planejamento do Distrito Federal - Codeplan. Disponível em: http://www.codeplan.df.gov.br/areas-tematicas/pesquisas-socioeconomicas.html, acesso em $15 / 10 / 2013$.

DISTRITO FEDERAL. Lei Complementar $n^{\circ}$ 803, de 25 de abril de 2009: aprova a revisão do Plano Diretor de Ordenamento Territorial do Distrito Federal. Brasília, 2009.

DISTRITO FEDERAL. Lei n 47, de 2 de outubro de 1989.

DISTRITO FEDERAL. Projeto de Lei Complementar no 52/2012. PPCUB. Disponível em: http://legislacao.cl.df.gov.br/Legislacao/consultaProposicao-8!52!2012!visualizar.action

DISTRITO FEDERAL. Projeto de Lei Complementar no 78/2013. PPCUB. Disponível em: http://legislacao.cl.df.gov.br/Legislacao/consultaProposicao-8!78!2013!visualizar.action

DISTRITO FEDERAL. Secretaria de Estado de Desenvolvimento Urbano e Meio Ambiente. Plano Diretor de Ordenamento Territorial do Distrito Federal -Documento Técnico - Versão Final - Novembro/2009.

DISTRITO FEDRAL. Relatório de Auditoria: Avaliação da Destinação de Recursos para Obras em Andamento e os Procedimentos Afetos às Atividades de Manutenção dos Bens Públicos. Secretaria de Macroavaliação Da Gestão Pública. Tribunal de Contas do Distrito Federal. Julho de 2012. Disponível em: http://www.tc.df.gov.br no link "Controle Externo > Auditorias". Acesso em 15/02/2015.

DUARTE, Maria de Souza. Educação pela arte: o caso de Brasília. Brasília: Editora Universidade de Brasília, 2011 (1ª edição 1983) 
FARIA, Gabriela Barbosa de. "O turismo em Brasília á luz da interpretação do patrimônio". In: STEINBERGER, Marília (org.) Territórios Turísticos no Brasil Central. Brasília: LGE Editora, 2009. p. 249-273

FERREIRA, A. B. H. Novo dicionário da língua portuguesa. $2^{\mathrm{a}}$ edição. Rio de Janeiro. Nova Fronteira. 1986. p. 1.282.

FONSECA, Maria Cecília Londres. "Para além da pedra e cal" In: ABREU, Regina \& CHAGAS, Mário (orgs.). Memória e Patrimônio: ensaios contemporâneos. $2^{\mathrm{a}}$ ed. Rio de Janeiro: Lamparina, 2009. p. 59-79

GASTAL, Susana e MOESH, Marustschka M. Turismo, políticas públicas e cidadania. São Paulo: Aleph, 2007. (Série Turismo)

GASTAL, Susana. Lugar de memória: por uma nova aproximação. GASTAL, Susana; BENI, Mário Carlos; CASTROGIONANNI, Carlos (orgs.). In: Turismo investigação e crítica. São Paulo : Contexto, 2002 (Coleção Turismo Contexto)

GEERTZ, Clifford. A interpretação das culturas. Rio de Janeiro: LTC - Livros Técnicos e Científicos Editora, 1989.

GONÇALVES, José Reginaldo Santos. "O patrimônio como categoria de pensamento" In: ABREU, Regina \& CHAGAS, Mário (orgs.). Memória e Patrimônio: ensaios contemporâneos. 2 ed. Rio de Janeiro: Lamparina, 2009. p. 25-33.

HALL, Stuart. "Quem precisa de identidade?" In: SILVA, Tomaz Tadeu da (org.). Identidade e diferença: a perspectiva dos estudos culturais. 12. ed. Petrópolis, RJ: Vozes, 2012. p. 103133

HALL, Stuart. A identidade cultural na pós-modernidade. Tradução Tomaz Tadeu da Silva, Guaracira Lopes Louro. 11 ${ }^{\mathrm{a}}$ edição, $1^{\mathrm{a}}$ reimpressão, Rio de Janeiro: DP\&A, 2011.

HARTOG, François. Tempo e Patrimônio. In: Varia Historia, Belo Horizonte, vol.22, $\mathrm{n}^{\mathrm{o}}$ 36, Jul/Dez 2006. p. 261-273.

INSTITUTO DO PATRIMÔNIO HISTÓRICO E ARTÍSTICO NACIONAL. Disponível em: www.iphan.gov.br.

JAFARI, Jafar. "La cientificación del turismo". In: Estudios y Perpectivas en Turismo. Volume 3, Número 1, Janeiro de 1994. CIET.

JORNAL CORREIO BRAZILIENSE. Mais proteção ao patrimônio. Sessão Cidades. p. 27. Data: $25 / 10 / 2011$.

JORNAL CORREIO BRAZILIENSE. Uma caixa d'água cercada de história. Sessão Cidades. p. 38. Data: 21/11/2013.

KRIPPENDORF, Jost. Sociologia do Turismo: para uma nova compreensão do lazer e das viagens. $2^{\mathrm{a}}$ edição, São Paulo: Aleph, 2001 (Série Turismo).

Le GOFF, Jacques. História e memória. Tradução Bernardo Leitão. Campinas, SP: Editora da Unicamp. 1990. p. 423-478

MAFFESOLI, Michel. Notas sobre a pós-modernidade: o lugar faz o elo. Rio de Janeiro: Editora Atlântica, 2004. 
MAPA 1: Extraído do Termo de Referência para Contratação do Plano de Preservação do Conjunto Urbanístico de Brasília. Secretaria de Estado de Desenvolvimento Urbano e Meio Ambiente do Distrito Federal. Brasília - dezembro de 2007.

MOLINA, Sergio. O pós-turismo. São Paulo: Aleph, 2003. (Série Turismo)

NUNES, José Walter. Patrimônios subterrâneos em Brasília. São Paulo : Annablume, 2005.

MINISTÉRIO DA CULTURA. Ofício $n^{\circ}$ 358/Dephan. Extraído de: ARAUJO, Raphael Ferreira de. "Catetinho: patrimônio esquecido de Brasília". 102f. Monografia (Pós-Graduação Lato Sensu - Curso de Especialização de Professores em Turismo) Universidade de Brasília, Brasília, 2009. p. 84

MINISTÉRIO DA CULTURA. Metas do Plano Nacional de Cultura. Dezembro de 2011. Disponível em: <http://portalpbh.pbh.gov.br/pbh//files./MetasPNC.pdf> Acesso em $13 / 06 / 2013$.

OLIVEIRA, Lúcia Luppi. Cultura é Patrimônio: um guia. Rio de Janeiro: Editora FGV, 2008. 192 p.

OLIVEIRA, Rafael F. "Cidades e paisagens como bens culturais no pensamento em Geografia”. In Revista Espaço \& Geografia. UnB, Vol. 16, n² 2. 2013, pp. 747-779.

ORTIZ, Renato. Cultura Brasileira e Identidade Nacional. São Paulo: Brasiliense, 2012.

PESAVENTO, Sandra Jathay. Cultura e representações, uma trajetória. In: Anos 90, Porto Alegre, v.13, n. 23/24, p. 45-58, jan/dez, 2006.

POLLAK. Michael. "Memória e identidade social". In Revista Estudos Históricos. Rio de Janeiro, vol. 5, ${ }^{\circ}$. 10. 1992, p.200-212

PORTAL DO DISTRITO FEDERAL. Disponível em: http://www.df.gov.br/, acesso em 23/07/2013.

RIBEIRO, Sandra Bernardes. Brasília: Memória, cidadania e gestão do patrimônio cultural. São Paulo: Annablume, 2004. p. 77-122, 141-184

SECRETARIA DE GESTÃO DO TERRITÓRIO E HABITAÇÃO DO DISTRITO FEDERAL. Disponível em: http://segeth.df.gov.br/.

SECRETARIA DE TURISMO DO DISTRITO FEDERAL. Disponível em: http://setur.df.gov.br/.

UNESCO. Report of 24th session, Cairns - Australia. Paris, 16 February 2001. Disponível em: http://whc.unesco.org/en/sessions/24COM/documents/. Acesso em 20/03/2015.

UNESCO. Report of 27th session. Paris, 12 June 2003. Disponível em: http://whc.unesco.org/archive/2003/whc03-27com-24e.pdf. Acesso em 20/03/2015.

UNESCO. Report of 28th session. Suzhou, China. Paris, 15 June 2004. Disponível em: http://whc.unesco.org/en/sessions/28COM/documents/. Acesso em 20/03/2015.

UNESCO. Report of 34th session. Brasilia, Brazil. Paris, 1 June 2010. Disponível em: http://whc.unesco.org/en/sessions/34COM/documents/. Acesso em 20/03/2015. 
UNESCO. Report of 35th session. Paris, UNESCO Headquarters. Paris, 7 July 2011. Disponível em: http://whc.unesco.org/archive/2011/whc11-35com-20e.pdf. Acesso em 20/03/2015.

URRY, John. O olhar do turista: lazer e viagens nas sociedades contemporâneas. Tradução de Carlos Eugênio Marcondes de Moura. 3. Ed. São Paulo: SESC, 2001. (Coleção Megalópolis)

VIDAL, Laurent. De Nova Lisboa a Brasília: a invenção de uma capital (séculos XIX-XX). Brasília: Editora Universidade de Brasília, 2009.

WOODWARD, Kathryn. "Identidade e diferença: numa introdução teórica conceitual". In: SILVA, Tomaz Tadeu da (org.) Identidade e diferença: A perspectiva dos Estudos Culturais. Petrópolis, RJ: Vozes, 2012. p. 7-72. 
ANEXOS

ANEXO A

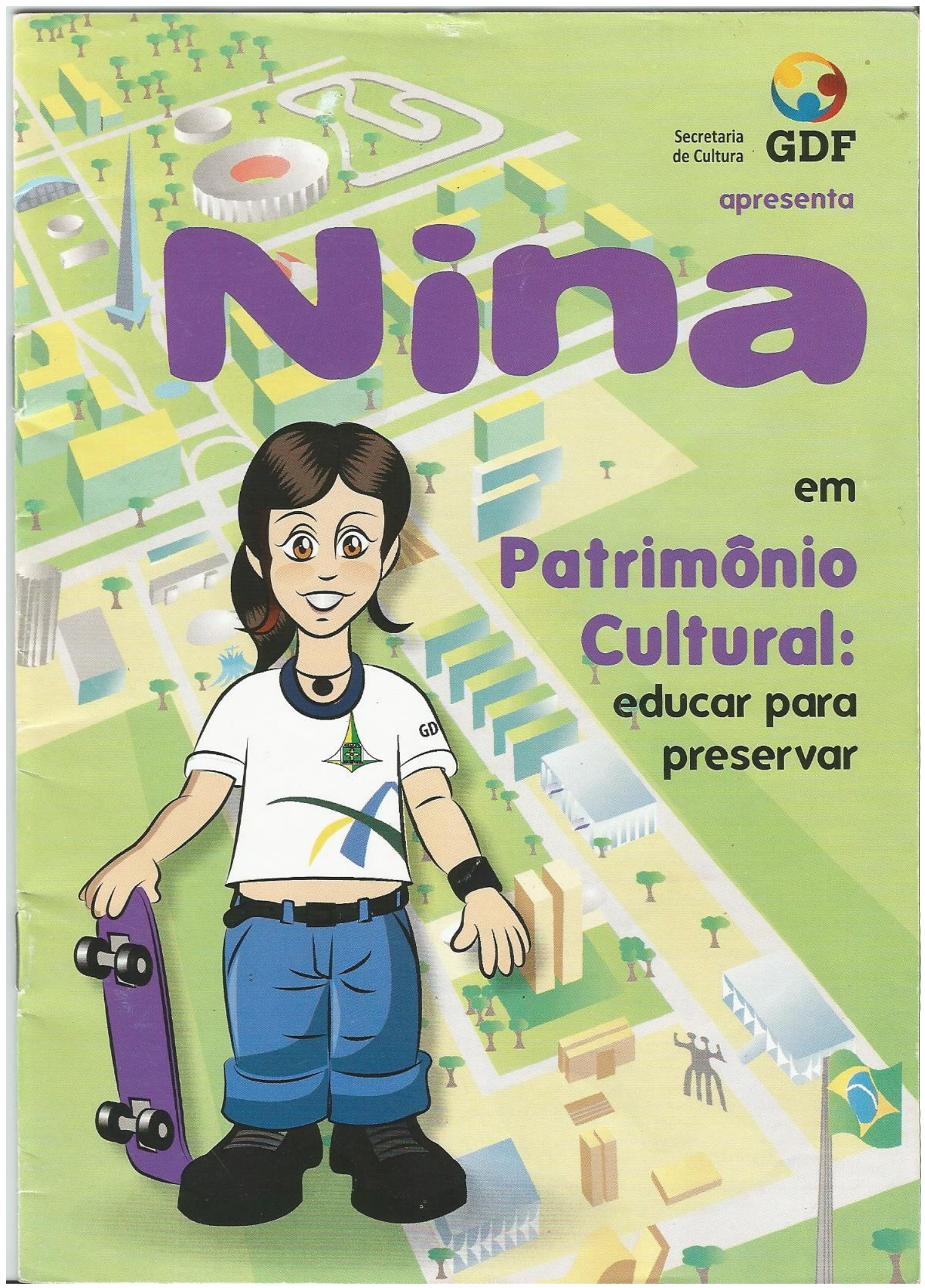



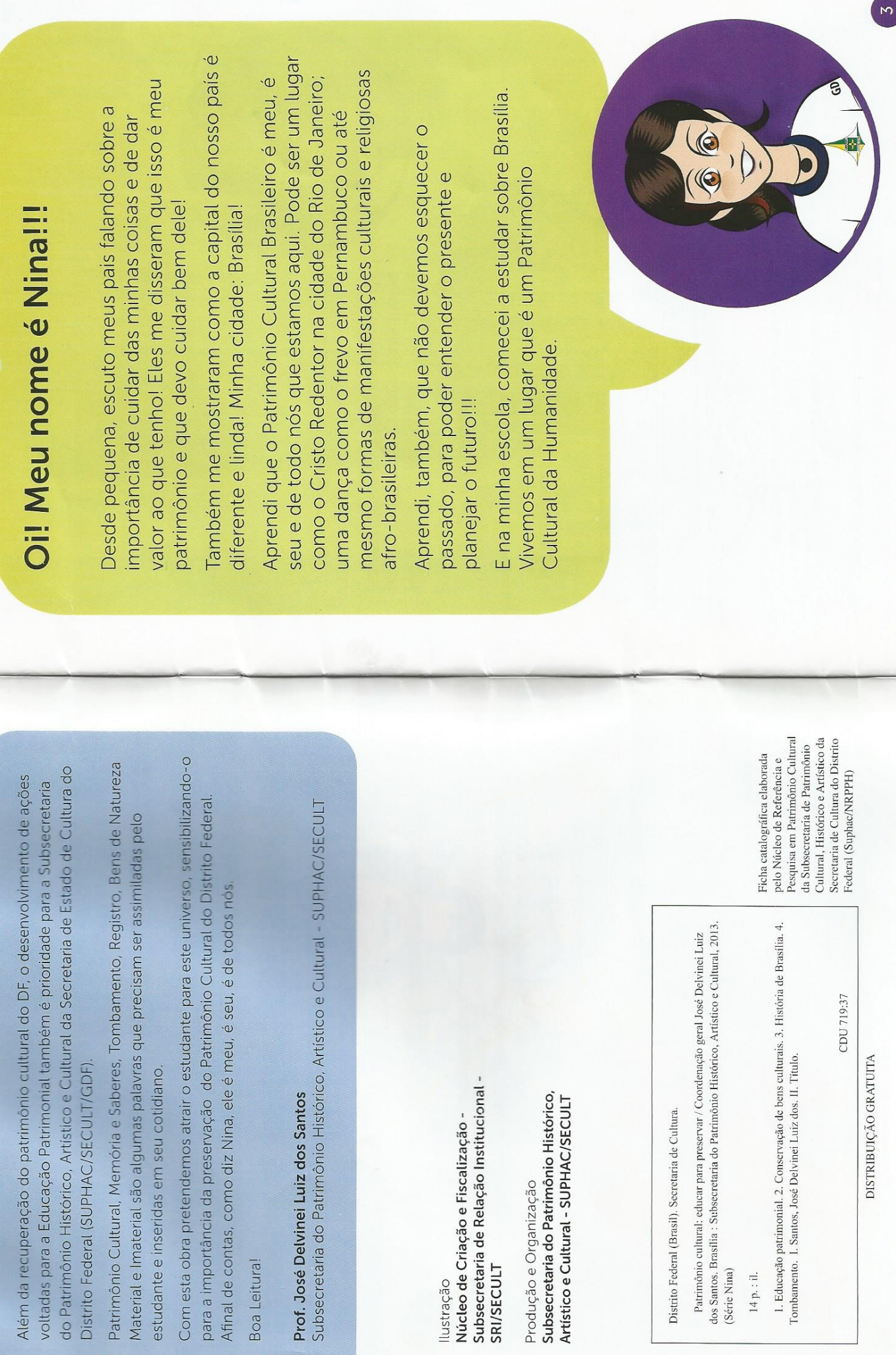

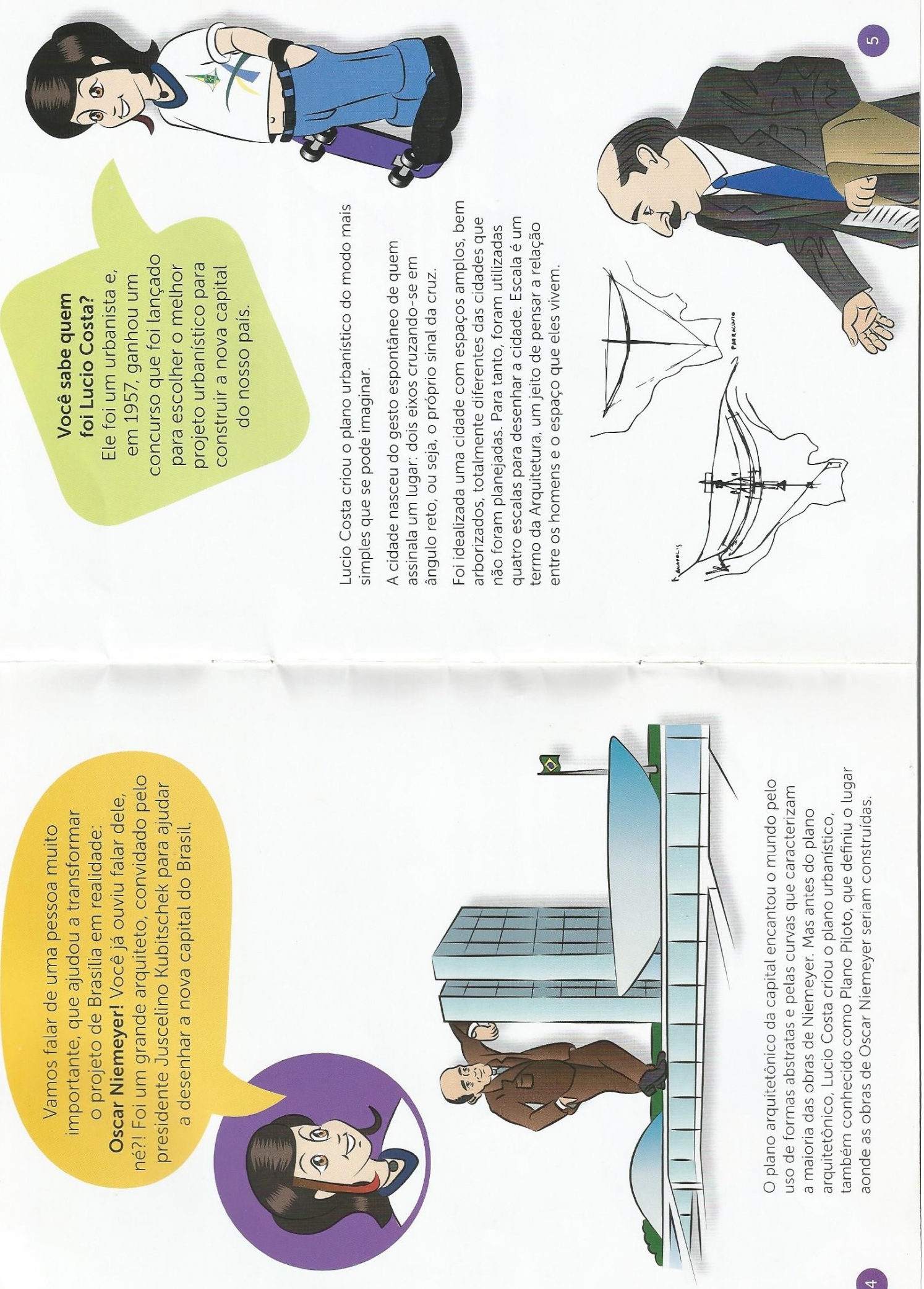


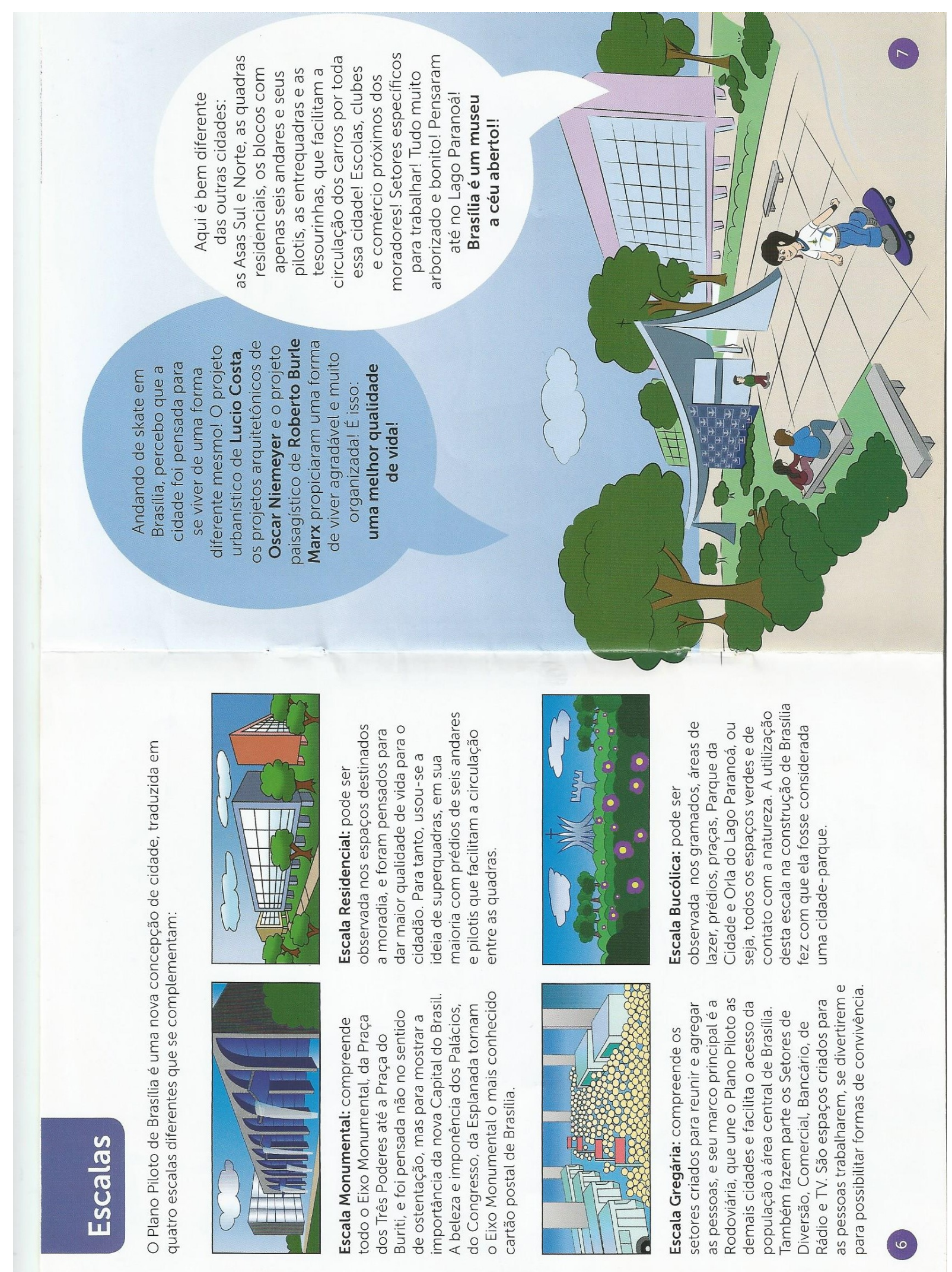




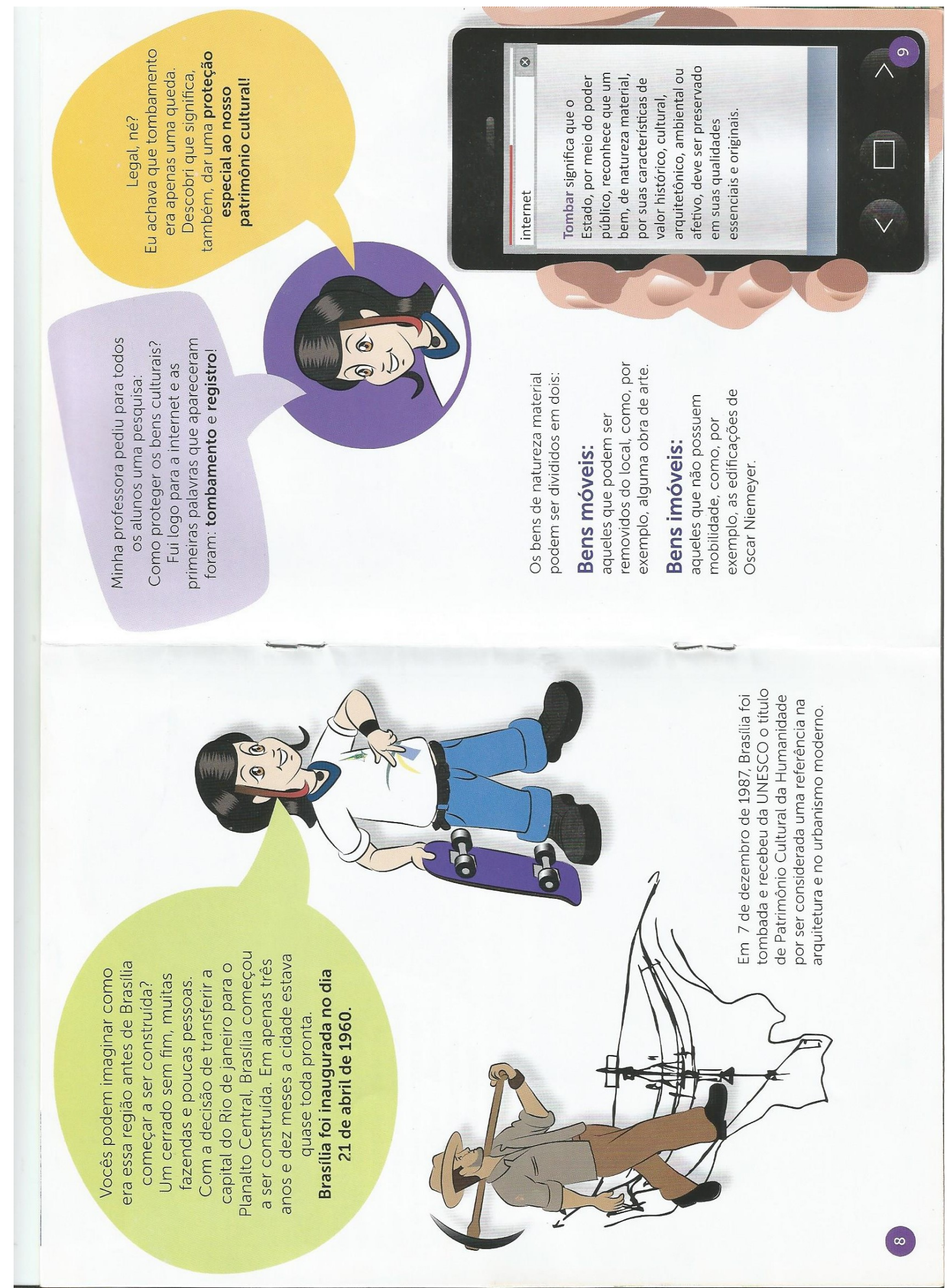




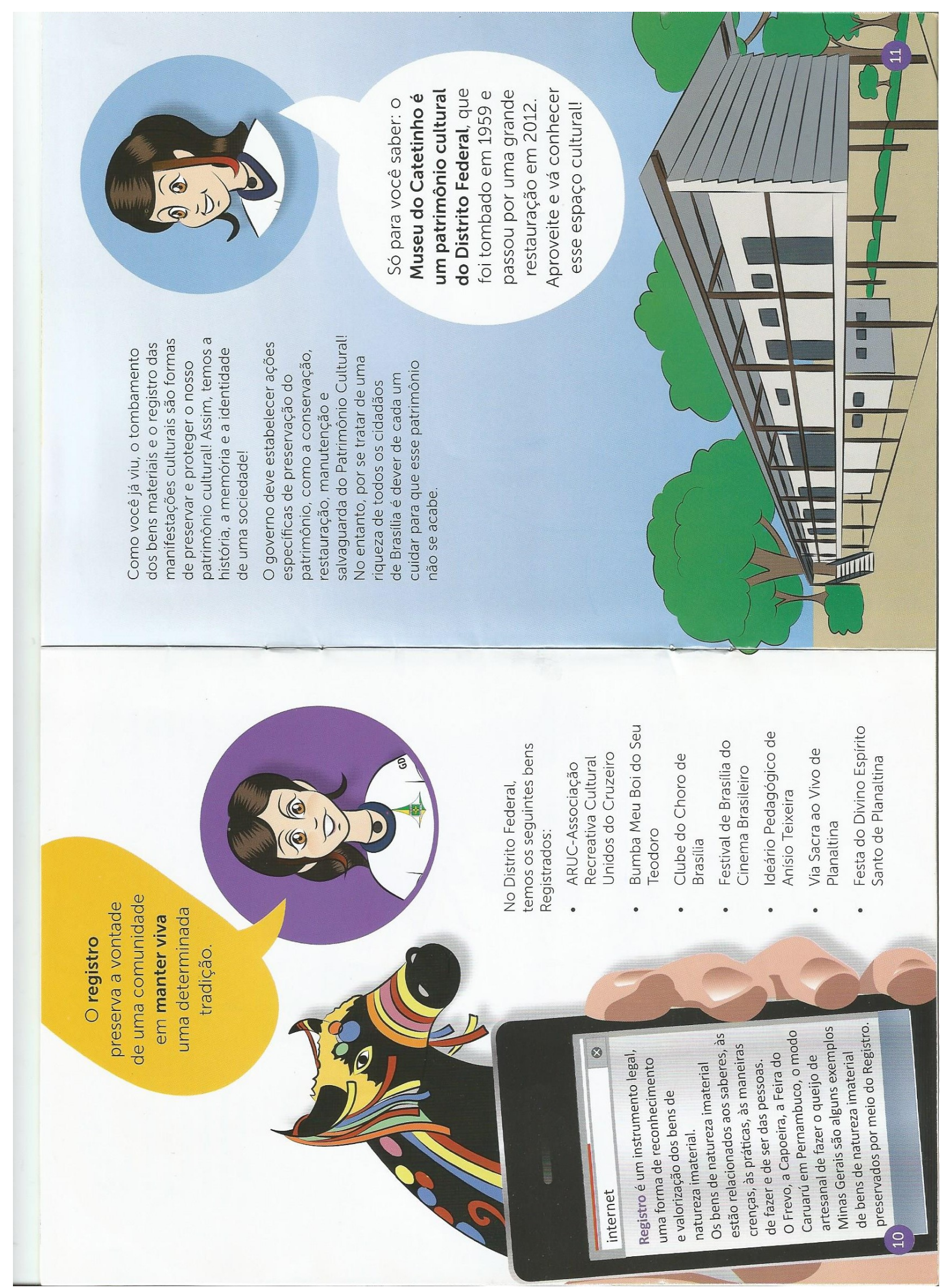




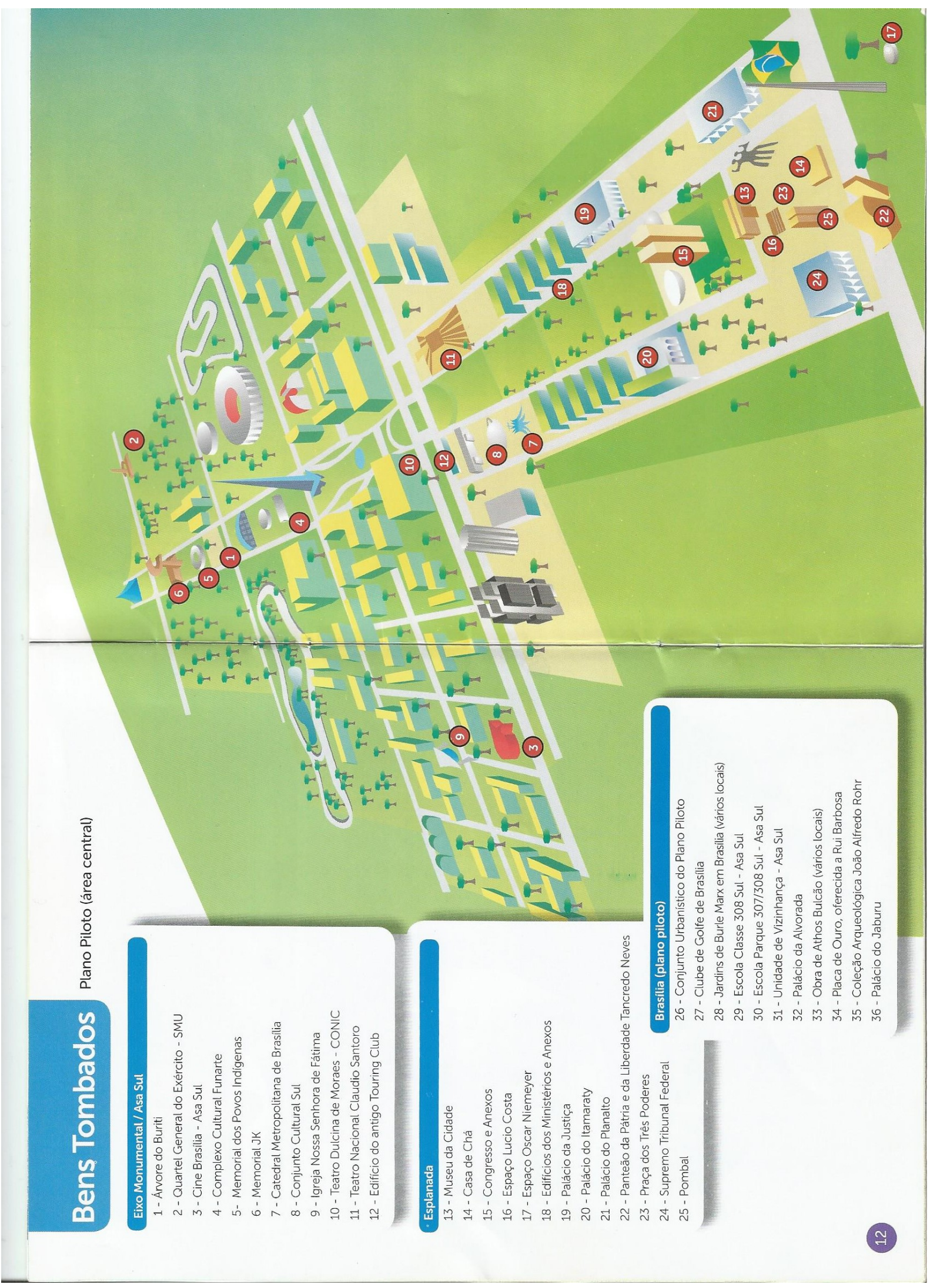




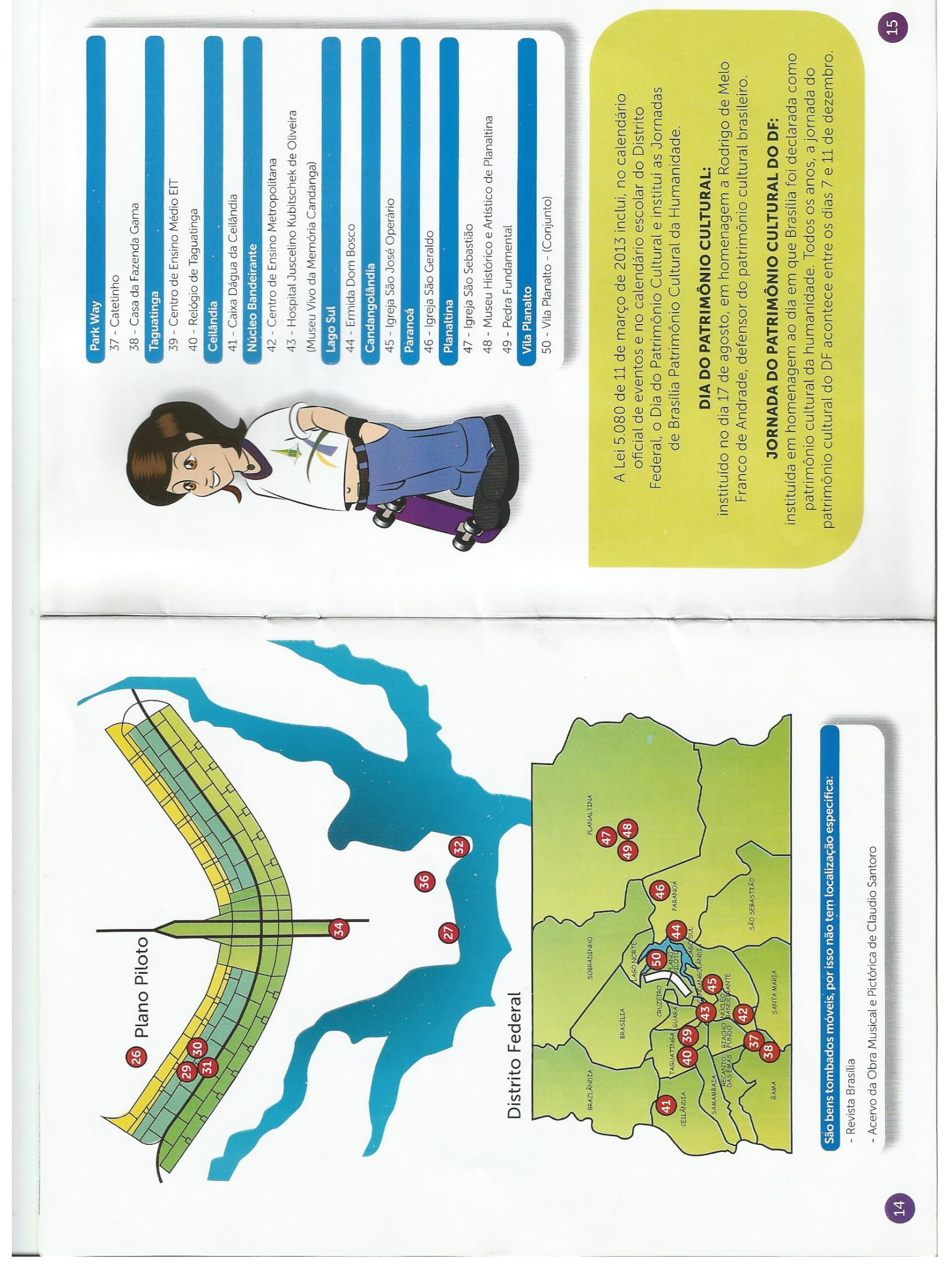




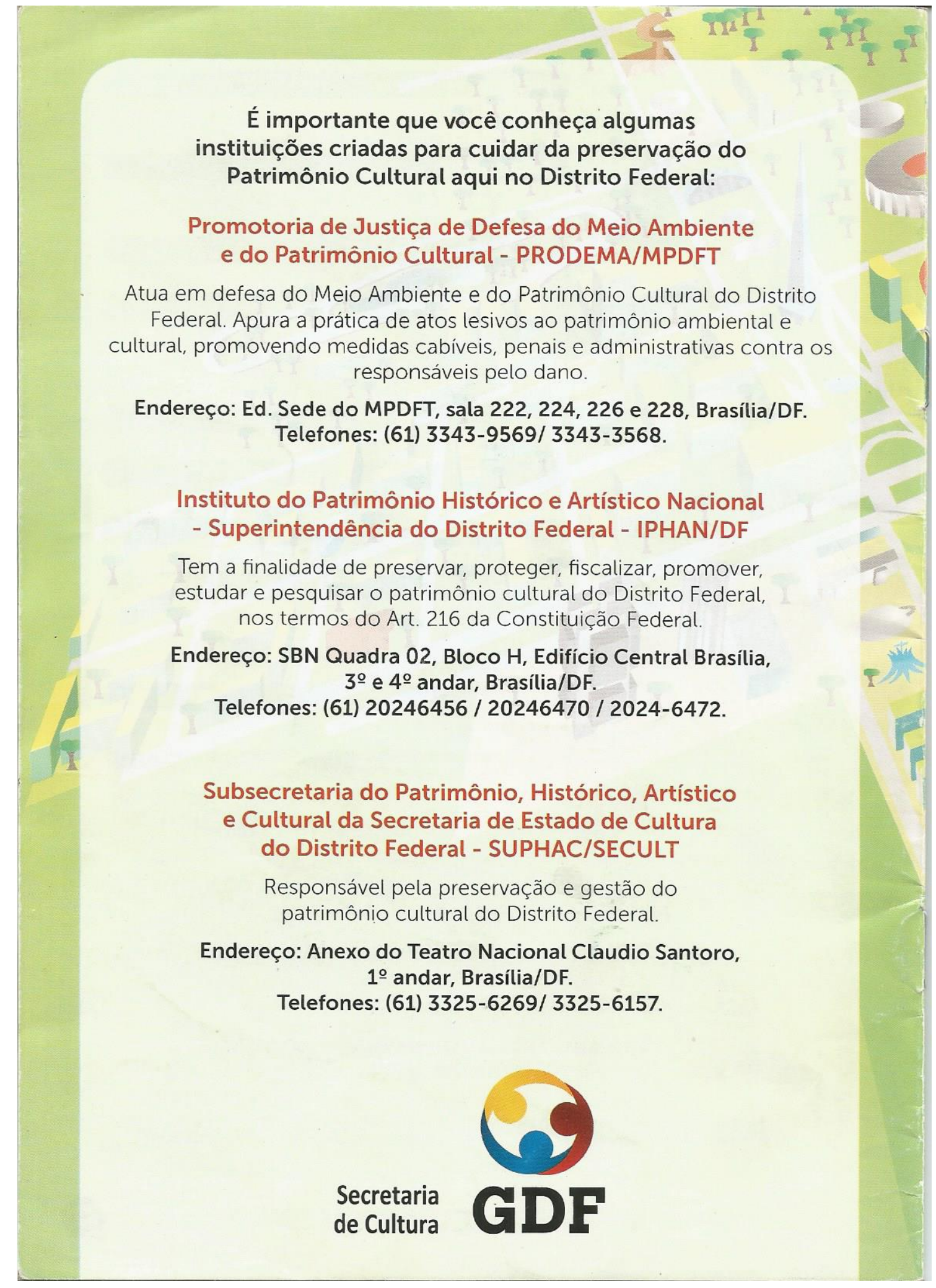




\begin{abstract}
ANEXO B
4-Brasília revisitada - Lúcio Costa

$1985 / 87$

Complementação, Preservação, Adensamento e Expansão urbana
\end{abstract}

Agradeço ao Governador José Aparecido de Oliveira bem como ao seu Secretário de Viação e Obras Carlos Magalhães por esta oportunidade de ainda fazer algumas ponderações.

Brasília vive hoje um momento decisivo. Nos trinta anos decorridos desde a apresentação do plano-piloto ao juri internacional que escolheria a proposta a ser implantada (I0/II//57) a cidade consolidou-se, de fato, como capital definitiva do país.

Vendo Brasília atualmente, o que surpreende, mais que as alterações, é exatamente a semelhança entre o que existe e a concepção original.

É evidente que uma cidade inaugurada há pouco mais de 25 anos está no começo de sua existência, passada a fase de consolidação a vitalidade urbana é manifesta e crescente, sobretudo agora, com o restabelecimento do poder civil que a gerou - Brasília preenche suas áreas ainda desocupadas e quer se expandir.

Não menos evidente é o fato de que - por todas as razões - a capital é histórica de nascença, o que não apenas justifica mas exije que se preserve, para as gerações futuras, as características fundamentais que a singularizam.

É exatamente na concomitância destas duas contingências que reside a peculiaridade do momento crucial que Brasília hoje atravessa: de um lado, como crescer assegurando a permanência do testemunho da proposta original, de outro, como preservá-la sem cortar o impulso vital inerente a uma cidade tão jovem.

"A liberação do acesso ao concurso reduziu de certo modo a consulta àquilo que de fato importa, ou seja, a concepção urbanística da cidade propriamente dita, porque esta não será, no caso, uma decorrência do planejamento regional, mas a causa dele, a sua fundação é que dará ensejo ao ulterior desenvolvimento planejado da região. Trata-se de um ato deliberado de posse, de um gesto de sentido ainda desbravador nos moldes da tradição colonial. E o que se indaga é como, no entender de cada concorrente, uma tal cidade deve ser concebida."(introdução à memória descritiva do plano-piloto) 
Assim, o plano-piloto (como de resto as outras propostas apresentadas) foi, na realidade, uma concepção já traduzida em termos de projeto urbano, e não apenas uma definição preliminar de partido e diretrizes gerais relativas a uso e ocupação do solo, e isto porque o objetivo era a transferência da capital — e não a elaboracão de projeto — em 3 anos.

"Se a sugestão é válida, estes dados, conquanto sumários na sua aparência, já serão suficientes, pois revelarão que apesar da espontaneidade original, ela foi, depois, intensamente pensada e resolvida."(memória descritiva do plano piloto.

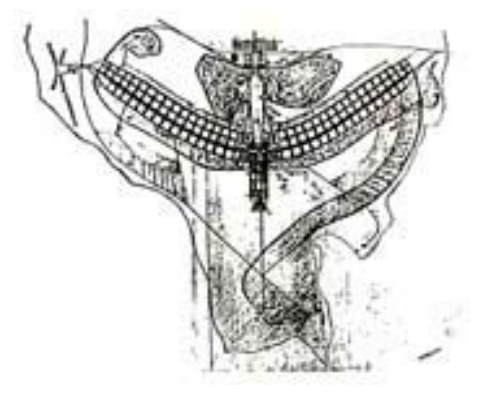

\section{CARACTERÍSTICAS FUNDAMENTAIS DO PLANO-PILOTO}

\section{1 - A interação de quatro escalas urbanas}

A concepção urbana de Brasília se traduz em quatro escalas distintas: a monumental, a residencial, a gregária e a bucólica.

A presença da escala monumental - "não no sentido da ostentação, mas no sentido da expressão palpável, por assim dizer, consciente daquilo que vale e significa" - conferiu à cidade nascente, desde seus primórdios, a marca inelutável de efetiva capital do país.

A escala residencial, com a proposta inovadora da Superquadra, a serenidade urbana assegurada pelo gabarito uniforme de seis pavimentos, o chão livre e accessível a todos através do uso generalizado dos pilotis e o franco predomínio do verde, trouxe consigo o embrião de uma nova maneira de viver, própria de Brasília e inteiramente diversa da das demais cidades brasileiras.

A escala gregária, prevista para o centro da cidade - até hoje ainda em grande parte desocupado - teve a intenção de criar um espaço urbano mais densamente utilizado e propício ao encontro.

As extensas áreas livres, a serem densamente arborizadas ou guardando a cobertura vegetal nativa, diretamente contígua a áreas edificadas, marcam a presença da escala bucólica.

A escala monumental comanda o eixo retilíneo - Eixo Monumental - e foi introduzida através da aplicação da "técnica milenar dos terraplenos "(Praça dos Três Poderes, Esplanada dos Ministérios), da disposição disciplinada porém rica das massas edificadas, das referências verticais 
do Congresso Nacional e da Torre de Televisão e do canteiro central gramado e livre da ocupação que atravessa a cidade do nascente ao poente.

As Superquadras residenciais, intercaladas pelas Entrequadras (comércio local, recreio, equipamentos de uso comum) se sucedem, regular e linearmente dispostas ao longo dos $6 \mathrm{~km}$ de cada ramo do eixo arqueado - Eixo Rodoviário-Residencial. A escala definida por esta sequência entrosa-se com a escala monumental não apenas pelo gabarito das edificações como pela definição geométrica do território de cada quadra através da arborização densa da faixa verde que a delimita e Ihe confere cunho de "pátio interno"urbano.

A escala gregária surge, logicamente, em torno da interseção dos dois eixos, a Plataforma Rodoviária, elemento de vital importância na concepção da cidade e que se tornou, além do mais, o ponto de ligação de Brasília com as cidades satélites. No centro urbano, a densidade de ocupação se previu maior e os gabaritos mais altos, à excessão dos dois Setores de Diversões.

E a intervenção da escala bucólica no rítmo e na harmonia dos espaços urbanos se faz sentir na passagem, sem transição, do ocupado para o não-ocupado - em lugar de muralhas, a cidade se propôs delimitada por áreas livres arborizadas.

\section{2 - A estrutura viária}

O plano de Brasília teve a expressa intenção de trazer até o centro urbano a fluência de tráfego própria, até então, das rodovias; quem conheceu o que era a situação do trânsito no Rio de Janeiro, por exemplo, na época, entenderá talvez melhor a vontade de desafogo viário, a idéia de se poder atravessar a cidade de ponta a ponta livre de engarrafamentos.

O que permanece incompreensível é até hoje não existir - pelo menos na área urbana - um serviço de ônibus municipal impecável, que se beneficie das facilidades existentes (apenas a título de exemplo: as pistas laterais do Eixo Rodoviário -Residencial - destinadas prioritariamente ao transporte coletivo - tem mão nos dois sentidos; no entanto sua utilização pelos ônibus só se faz

numa direção em cada uma delas). Bem como não se ter ainda introduzido o sistema de "transferência" que se impõe para que o passageiro não seja onerado indevidamente.

A estrutura viária da cidade funciona como arcabouço integrador das várias escalas urbanas.

\section{3 - A questão residencial}

O plano-piloto optou por concentrar a população próximo ao centro (Eixo RodoviárioResidencial), através da criação de áreas de vizinhança que só admitem habitação multifamiliar; mas habitação multifamiliar não na forma de apartamentos contruídos em terrenos inadequados e constrangendo os moradores das residências vizinhas, como geralmente ocorre. 
A proposta de Brasília mudou a imagem de "morar em apartamento", e isto porque morar em apartamento na Superquadra significa dispor de chão livre e gramados generosos contíguos à "casa" numa escala que um lote individual normal não tem possibilidade de oferecer.

E prevaleceu a idéia de distribuir a ocupação residencial em áreas definidas "a priori" para apartamentos (Superquadras) e para casas isoladas - estas, mais afastadas do centro.

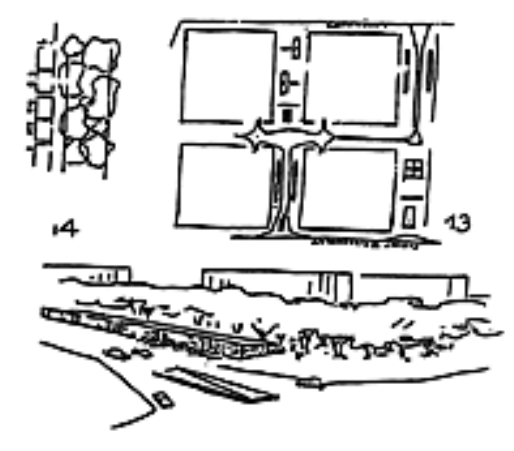

\section{4 - Orla do lago}

O Plano-piloto refuga a imagem tradicional no Brasil da barreira edificada ao longo da água; a orla do lago se pretendeu de livre acesso a todos, apenas privatizada no caso dos clubes. É onde prevalece a escala bucólica.

\section{5 - A importância do paisagismo}

"De uma parte, técnica rodoviária; de outra técnica paisagística de parques e jardins. "(memória descritiva do plano-piloto)

A memória descritiva do plano deixou clara a importância da volumetria paisagística na interação das quatro escalas urbanas da cidade; o canteiro central da Esplanada gramado, as cercaduras verdes das Superquadras, a massa densamente arborizada prevista para os Setores Culturais (ainda até hoje desprovidos de vegetação).

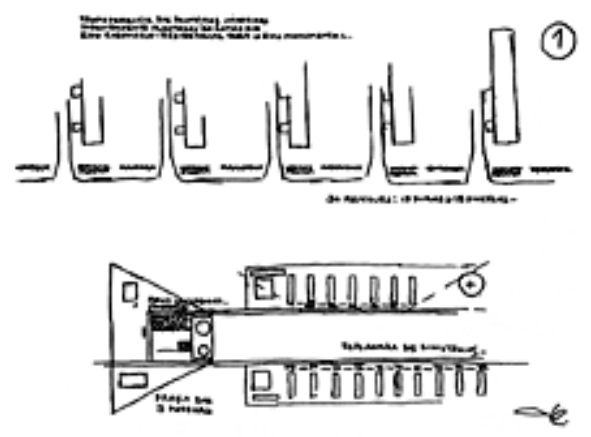


Daí a importância da remoção - enquanto é tempo - das palmeiras imperiais indevidamente plantadas ao longo do Eixo Rodoviário-Residencial para o Eixo Monumental; as razões desta impugnação foram claramente explicadas em dois pareceres anexados a este relato.

São de recomendar, ainda, providências imediatas para a criação de massas compactas de araucária na área abaixo do terrapleno da Praça dos Três Poderes, para que seu verde escuro sirva de fundo e valorize o branco dos palácios, bem como o plantio de renques de pau-rei no entorno direto do edifício do Tribunal de Contas da União - imperdoável aberração no local onde se encontra — a fim de atenuar sua lamentável interferência visual no conjunto da Praça.

\section{6 - A presença do céu.}

Da proposta do plano-piloto resultou a incorporação à cidade do imenso céu do planalto, como parte integrante e omnipresente da própria concepção urbana - os "vazios" são por ele preenchidos; a cidade é deliberadamente aberta aos 360 graus do horizonte que a circunda.

\section{7 - 0 não alastramento suburbano}

A implantação de Brasília, partiu do pressuposto que sua expansão se faria através de cidades satélites, e não da ocupação urbana gradativa das áreas contíguas ao núcleo original. Previa-se a alternância definida de áreas urbanas e áreas rurais - proposição contrária à idéia do alastramento suburbano extenso e rasteiro.

Assim, a partir do surgimento precoce e improvisado das cidades satélites, prevaleceu até agora a intenção de manter entre estes núcleos e a capital uma larga faixa verde, destinada a uso rural.

Tal abordagem teve como conseqüência positiva a manutenção, ao longo de todos esses anos, da feição original de Brasília. Mas, em contrapartida, a longa distância entre as satélites e o "Plano Piloto "isolou demais a matriz dos dois terços de sua população metropolitana que reside nos núcleos periféricos, além de gerar problemas de custo para o transporte coletivo.

Daí a proposta apresentada no início do atual governo da implantação de Quadras Econômicas - ou Comunitárias - ao longo das vias de ligação entre Brasília e as cidades satélites, sendo mantida a destinação das áreas aos fundos desta orla urbanizada à cultura hortogranjeira.

\section{COMPLEMENTAÇÃO E PRESERVAÇÃO}

Complementar e preservar estas características significa, por conseguinte:

1 - Proceder ao tombamento do conjunto urbanístico-arquitetônico da Praça dos Três Poderes, incluindo-se os palácios do Itamaraty e da Justiça, de vez que constituem sua vinculação 
arquitetônica com a Esplanada dos Ministérios, cuja perspectiva ficará valorizada com a transferência das palmeiras imperiais.

2 - Manter os gabaritos vigentes nos dois eixos e em seu entorno direto (até os Setores de Grandes Áreas, inclusive), permanecendo não edificáveis as áreas livres diretamente contíguas, e baixa a densidades, com gabaritos igualmente baixos, nas áreas onde já é prevista ocupação entre a cidade e a orla do lago. Isto é fundamental.

Brasília, a capital, deverá manter-se "diferente" de todas as demais cidades do país: não terá apartamentos de moradia em edifícios altos; o gabarito residencial não deverá ultrapassar os seis pavimentos iniciais, sempre soltos do chão. Este será o traço diferenciador - gabarito alto no centro comercial, mas deliberadamente contido nas áreas residenciais, a fim de restabelecer, em ambiente moderno, escala humana mais próxima da nossa vida doméstica e familiar tradicional.

3 - Garantir a estrutura das unidades de vizinhança do Eixo Rodoviário - Residencial, mantendo a entrada única nas Superquadras, a interrupção das vias que thes dão acesso - para evitar tráfego de passagem - bem como ocupando devidamente as Entrequadras não comerciais com instalações para esporte e recreio e demais equipamentos de interesse comunitário, sobretudo escolas públicas destinadas ao ensino médio. Proibir a vedação das áreas cobertas de acesso aos prédios (pilotis) e dos parqueamentos — cobertos ou não.

4 - Reexaminar os projetos dos setores centrais, sobretudo os ainda pouco edificados, no sentido de propiciar a efetiva existência da escala gregária - além da Rodoviária e dos dois Setores de Diversões - prevendo percursos contínuos e animados para pedestres e circulação de veículos dentro dos vários quarteirões, cuja ocupação deve, em princípio, voltar-se mais para as vias internas do que para as periféricas.

Neste mesmo sentido, não insistir na excessiva setorização de usos no centro urbano aliás, de um modo geral, nas áreas não residenciais da cidade, excetuando o centro cívico. $O$ que $o$ plano propôs foi apenas a predominância de certos usos, como ocorre naturalmente nas cidades espontâneas.

5 - Providenciar as articulações viárias necessárias para fazer prevalecer na cidade de hoje a mesma clareza e fluência viárias contidas no risco original e, paralelamente, "arrematar" a cidade como um todo (recomendo neste sentido consulta ao trabalho "Brasília 57-85")

6 - Proceder urgentemente às obras de recuperação da Plataforma Rodoviária, que devem ser coordenadas por arquiteto identificado com o projeto original, a ser mantido com rigorosa fidelidade. 
7 - Acabar devidamente e manter sempre limpos os logradouros de estar. A começar pelas duas pracinhas da Plataforma Rodoviária - cuidar das plantas, dos bancos e do permanente funcionamento das fontes.

\section{ADENSAMENTO E EXPANSÃO URBANA DO "PLANO PILOTO"}

Uma vez assegurada a proteção do que se pretende preservar, trata-se agora de verificar onde pode convir ocupação - predominantemente residencial - em áreas próximas do "Plano Piloto", ou seja, na bacia do Paranoá, e de que forma tal ocupação deve ser conduzida para integrarse ao que já existe, na forma e no espírito, ratificando a caracterização de cidade parque "derramada e concisa" — sugerida como traço urbano diferenciador da capital.

Como já foi mencionado, a primeira proposição neste sentido foi a implantação intermitente de seqüências de Quadras Econômicas ao longo das vias de ligação entre Brasília e as cidades satélites. A proposta visou aproximar de Brasília as populações de menor renda, hoje praticamente expulsas da cidade - apesar da intenção do plano original ter sido a oposta - e, ao mesmo tempo, dar também a elas acesso à maneira de viver própria da cidade e introduzida pela superquadra.

Na Quadra Econômica - espécie de "pré-moldado" urbano - a disposição escalonada dos blocos (pilotis e três pavimentos) ao longo da trama viária losangular abre, no interior de cada quadra espaço livre para instalação dos complementos da moradia: lugar para jogos ao ar livre, "áreas de encontro" cobertas para os moços e para os velhos, creche, jardim de infância. A existência deste "quintal comum", com a quase totalidade de chão aberta ao uso de todos, e desses complementos ou "extensões da habitação", ensejando desafogo de tensões, possibilitam convívio doméstico em clima de descontração, mesmo em apartamentos mínimos, além de assegurar boa densidade populacional (cerca de 500 hab/ha). Ao mesmo tempo, essa implantação compacta reduz sensivelmente o custo da infraestrutura urbana uma vez que não compromete grandes superfícies.

Quando, ao longo das vias de ligação, for fisicamente inviável a implantação de Quadras Econômicas, podem ser admitidos núcleos residenciais multifamiliares de outro tipo, desde que com gabarito máximo de pilotis e quatro pavimentos e taxa de ocupação do terreno análogas às das quadras. Em qualquer caso, deve ser reservada faixa contígua à estrada para densa arborização.

Chegando a Brasília propriamente dita, seis áreas comportam ocupação residencial multifamiliar; sendo diretamente vinculadas ao "Plano Piloto" passam, por conseguinte, a interferir no jogo das escalas urbanas.

As duas primeiras ( $A$ e B), na parte oeste da cidade, resultam da distância excessiva entre a Praça Municipal e a Estrada Parque Indústria e Abastecimento decorrente do deslocamento do conjunto urbano em direção ao lago recomendado por Sir William Holford no julgamento do concurso.

A terceira (C), já proposta em 1984, está ligada à intenção de se fixar a Vila Planalto. 
A quarta (D), é sugerida pela existência de centros comerciais consolidados na área fronteira.

$E$ as duas últimas $(E$ e $F)$ visam abrir perspectiva futura de maior oferta habitacional multifamiliar em áreas que, embora afastadas, vinculam-se ao núcleo original tanto através da presença do lago como pelas duas pontes que se pretende construir (a primeira pessoa a me alertar para tal possibilidade foi o economista Eduardo Sobral, mais de 10 anos atrás). Poderiam ser chamadas "Asas Novas" - Asa Nova Sul e Asa Nova Norte.

$\mathrm{Na}$ implantação dos dois novos bairros a oeste — Oeste Sul e Oeste Norte - foram previstas Quadras Econômicas (pilotis e três pavimentos) para responder à demanda habitacional popular e Superquadras (pilotis e seis pavimentos) para classe média, articuladas entre si por pequenos centros de bairro, com ocupação mais densa, gabaritos mais baixos(dois pavimentos sem pilotis) e uso misto.

A idéia de se implantar um renque de pequenas Quadras $(240 \times 240 \mathrm{~m})$ com gabarito de quatro pavimentos sobre pilotis ao longo da via localizada entre a Vila Planalto e o Palácio da Alvorada (área C) surgiu como única forma realista de, uma vez admitida a fixação da Vila, barrar de fato a gradual expansão de parcelamento em lotes individuais naquela direção, o que interferiria de forma não apenas inadequada mas desastrosa com a escala monumental tão próxima; à primeira vista, a presença destas quadras — Quadras Planalto — pode parecer contraditória com a recomendação de se manterem baixos a densidade e os gabaritos nas áreas onde é admitida ocupação entre o "Plano Piloto" e a orla do lago; na realidade, entretanto, o gabarito uniforme de quatro pavimentos ao longo de cerca de 1.000 metros cria uma dominante horizontal serena que, aliada à presença indispensável - dos enquadramentos arborizados das Quadras assegura a harmonia do conjunto com seu entorno.

A ocupação residencial da quarta área (D) só é admissível na forma de renque singelo de pequenas quadras (como as Quadras Planalto, com pilotis e quatro pavimentos) ou de Quadras Econômicas (pilotis e três pavimentos). Em razão da localização desta área, a fim de evitar interferência negativa com o Eixo Rodoviário sul, além do gabarito ser mais baixo, toda a extensão de terreno compreendida entre as novas quadras e o Eixo deve permanecer não edificada ou destinada a usos que impliquem em baixa densidade de ocupação, e sempre cobertas de verde para diluir no arvoredo as construções.

A área E - Asa Nova Sul - sugere ocupação linear, também na forma de pequenas quadras como as Quadras Planalto, com gabarito uniforme de 4 pavimentos sobre pilotis e cercadura arborizada.

Já na área $F$, muito mais extensa e com topografia peculiar, a ocupação deve prever Quadras Econômicas ou conjuntos geminados para atender à população de menor renda, e considerar a eventual possibilidade de fixacão, em termos adequados, da atual Vila Paranoá, Os demais núcleos de edifícios residenciais devem ser soltos do chão, tendo, no máximo, 4 pavimentos e com gabarito 
de preferência uniforme para que se mantenha, apesar da ocupação, a serenidade da linha do horizonte, sendo cada conjunto, - desta vez de fato e de saída - emoldurado por farta arborização. Os centros de bairro, mais densamente ocupados, devem sempre ter gabaritos mais baixos.

Nessas "Asas Novas", mesmo quando de configuração diversificada, deve também prevalecer a mesma conotação de cidade parque, vale dizer, pilotis livres, predomínio de verde, gabaritos baixos.

Convém ainda destinar parte da Asa Nova Norte a parcelamento em lotes individuais, aproveitando os caprichos da topografia, respeitada a proteção arborizada dos córregos e nascentes. Assim, esta expansão futura atenderá às três faixas de renda.

No intuito de tornar a área das "Mansões" criadas por Israel Pinheiro economicamente mais adequadas, propõe-se admitir nelas uso condominial, onde metade da área original, ou seja, 10.000 $\mathrm{m} 2$, seriam preservados para a casa matriz, podendo a outra metade comportar até 5 novas unidades, todas com entrada comum - independentemente ou não da entrada principal - e constituindo um só conjunto embora sendo, eventualmente, delimitadas por cercas vivas; seria também admissível nessas áreas a instalação de clubes de recreio.

E convém insistir no atendimento à necessidade de habitação popular através da implantação, em grande escala, de Quadras Econômicas, apelando inclusive para as possibilidades da fabricação em série, dentro da tecnologia desenvolvida pelo arquiteto João Filgueiras Lima, e que já conta com fábrica montada em Brasília.

Tudo depende, em última análise, de decisão convicta neste sentido - os meios de fazer acabam aparecendo. Como capital, cabe a Brasília inovar na matéria, mostrando ao país que existe esta alternativa aos tristes aglomerados monótonos de casinholas pseudo-isoladas que proliferam, e se tornaram a imagem melancólica do $\mathrm{BNH}$.

Se computado o custo verdadeiro de cada unidade residencial - incluindo terreno, infraestrutura urbana e construção dos blocos de apartamentos e dos "complementos da moradia", cai por terra a idéia da casa isolada ser a solução economicamente mais viável para o problema da habitação popular. Tanto assim que em países com Cuba e China, onde o caixa é único e o dinheiro pouco, não se cogita de assentamentos residenciais rasteiros, até mesmo em áreas rurais. Além do que, o lote mínimo, com janelas confrontando e seu quintal inexistente porque em geral ocupado por outra família, nada tem a ver com a imagem romântica que se propaga da "casa própria".

Em todo o caso, para atendimento à demanda popular nos moldes tradicionais - lotes individuais - existe o projeto Samambaia, elaborado por técnicos do GDF na administração passada, inclusive com esta intenção.

\section{CONCLUSÃO}


O "quantum" populacional atingido pela abertura à ocupação dessa novas áreas, pelos adensamentos previstos, pela ocupação residencial multifamiliar nas margens das vias de ligação entre Brasília e as satélites, pelo adensamento controlado destes núcleos e pela implantação da Samambaia, deve ser considerado a população limite para a capital federal, a fim de não desvirtuar a função primeira - político-administrativa - que lhe deu origem. A Brasília não interessa ser grande metrópole.

Como nossa estrutura econômico-social induz à migração de populações carentes para os grandes centros urbanos, é essencial pensar-se desde já no desenvolvimento, em áreas próximas à capital de núcleos industriais capazes de absorver, na medida do possível, essas migrações com efetiva oferta de trabalho. Brasília não é, no caso, uma simples miragem. Cidade fundamentalmente político-administrativa e de prestação de serviços, a demanda de mão de obra, sobretudo não qualificada, é necessariamente menor embora a proximidade do poder central crie a ilusão de facilidades que, de fato, não existem.

Quanto ao escalonamento, no tempo, das implantações aqui sugeridas cabe ao Departamento de Urbanismo da Secretaria de Viação e Obras coordenar os estudos a serem feitos conjuntamente com as demais Secretarias e concessionárias de serviços públicos a fim de definir com segurança o melhor procedimento, bem como as tecnologias a serem utilizadas, tendo em vista o abastecimento de água e energia, o transporte, o saneamento e a preservação do meio ambiente, o controle da poluição do Lago Paranoá e a proteção da área a ser ocupada pela futura represa do São Bartolomeu - integrando, enfim, como um todo, as novas proposições e o planejamento do território do Distrito Federal.

Finalmente, o importante ao se pensar na complementação, na preservação, no adensamento ou na expansão de Brasília é não perder de vista a postura original, é estar-se imbuído de lucidez e sensibilidade no trato dos problemas urbanos; é perceber que coisas maiores e coisas menores têm importância análoga, consideradas cada uma em sua escala; é enfrentar os inúmeros problemas do dia a dia com disposição, firmeza e flexibilidade; é tanto saber dizer não como dizer sim na busca contínua da resposta adequada, - tarefa tantas vezes ingrata e inglória para os técnicos que participam dedicadamente de sucessivas administrações ; é fazer prevalecer o senso comum, fugindo das teorizações acadêmicas e protelatórias, e da improvisação irresponsável. É lembra-se que a cidade foi pensada "para o trabalho ordenado e eficiente, mas ao mesmo tempo cidade viva e aprazível, própria ao devaneio e à especulação intelectual, capaz de tornar-se, com o tempo, além de centro de governo e administração, num foco de cultura dos mais lúcidos e sensíveis do país."

O plano-piloto de Brasília não se propôs visões prospectivas de esperanto tecnológico, nem tampouco resultou de promiscuidade urbanística, ou de elaborada e falsa "espontaneidade". 
Brasília é a expressão de um determinado conceito urbanístico, tem filiação certa, não é uma cidade bastarda. O seu "facies" urbano é o de uma cidade inventada que se assumiu na sua singularidade e adquiriu personalidade própria graças à arquitetura de Oscar Niemeyer e à sua gente.

(Extraído do COE - Código de Obras e Edificações - Brasília, DF) 


$$
\text { D.P.II.A.It. }
$$
\end{abstract}

ANEXO C

or. $n^{2} / 35$

Diretor do Patrinônio Histórico e frtístico Vacional

Sr. Presicento da Conpunia Urbanizaciom da Hovia Cupital do Lrasil

Se hor Presidente:

itavendo o Senhor Presidente da República cieterninz-

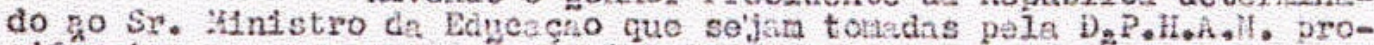

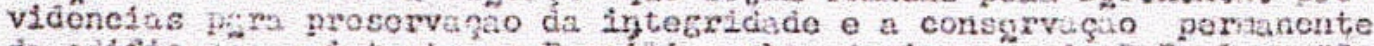
di edilic-zio oxietente en Brasilia sob a ciesignggäo de R.P. 1 ou "C tetigho", nodida egsa justiflcida jor ter sido njo so a prineir cons truça erigien na grea da nova c pital, ma tanbén a prinelra secie da adninisugegeo publice no local, venho pleitenx a viliosa e decini-

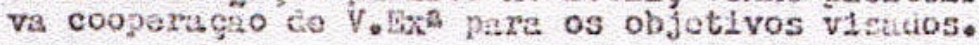

Nasso seritido, solicito-lile inicialnente o favor de transnitir Instrucooss a quen de girelto a fin da nenejonada edificaça ver protegidn e zeladia de ecortio con a, deterainaço presíancial, nao sendo totncis Intciktive al guna susceptivel de altorar-2iro as caricteristicus originais, nen nodificar-lino o aspeto prinitivo. in segundo lugar, pogo-ing expedir as ordens nogeseuri,us pira que o taobj Iiirio e as instilaçoos de casa sojan tenben rosguardados, diflfenc1ando-se a $11 \pm$ de quo a mesma preserve, intema e externumonte, is disposiço $\odot$ os elestentos que possuia enquanto serviu de residenciu o fit

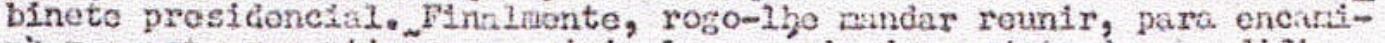
njar a esta repericicăo, o original ou copia do projeto da edjilcafao, de antoria do erculteto Oscar llienojer, Len cono a documontagio fotografica que houver sido folta durantye as divorgas fases da raspotiva constructa o dopois dia obra concluida e, por ultimo, reprasentan do sou estado atual, tanto externo cuanto interno.

Desdo já muito reconhecido a sę̃ precioso concurso,

apresento a $V . F x$ os protostos de nou elovado apréco.

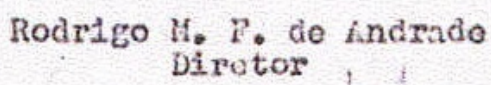

Ao Sentior

Dr. Israel Pinheiro

Presidente da Companiala Urbenizadora da Nova Capital.

Rua wlairimte Barroso, $54-130$ ander

RIO DË JAIEilEO - D.F。

$\mathrm{ra} / \mathrm{rc}$. 


\section{ANEXO D}

\section{ICOMOS}

INTERNATIONAL COUNCIL ON MONUMENTS AND SITES CONSEIL INTERNATIONAL DES MONUMENTS ET DES SITES CONSEJO INTERNACIONAL DE MONUMENTOS Y SITIOS МЕЖЛУНАРОДНЫЙ СОВЕТ ПО ВОПРОСАМ ПАМЯТНИКОВ И ДОСТОПРИМЕЧАТЕПЬНЫХ МЕСТ WORLD HERITAGE LIST $N^{\circ} \quad 445$

\section{A) IDERTIF ICATION}

Nomination: Brasilia

Location : Federal District

State Party : Brazil

Date : December 31,1986

\section{B) ICOHOS RECOMHENDATION}

That the proposed cultural property be included on the World Heritage List on condition that the Brazilian authorities adopt a legislation that would ensure the safeguarding of the urban creation of Costa and Niemeyer.

\section{C) JUSTIFICATION}

The 20 th century principles of urbanism, as expressed in 1943 in the Athens Charter or in the 1946 Manière de penser l'urbanisme by Le Corbusier, have rarely been appliedat the scale of capital cities. Only two noteworthy exceptions exist: Chandigarh, where Le Corbusier, commissioned by the Punjab government in 1950 to act as architectural adviser, worked for several years in collaboration with Plerre Jeanneret, Maxwell Fry and Jane Drew, and Brasilia, created ex nihilo at the centre of a $5814 \mathrm{~km} 2$ federal district in 1956 .

The idea of building a capital in the interior of Brazil is an old one, having been proposed on various occasions since the end of the 17 th century. In 1922, at the time of the centennial celebrations commemorating Brazilian independence, the cholce of the central western region as a site for the future capital was iliustrated by the dedication of the "Foundation Stone" several kilometers northeast of the present location of Brasilia, near Planaltina.

Elected president of the Republic of Brazil in 1955, Juscelino Kubltschek made the creation of the capital city a symbol of his policy to upgrade the image of the entire country, to expand industry and to undertake major construction projects.

In 1956, President Kubitschek appointed a commission to determine an exact location for the city and set up an executive body, the Novacap, to supervise and ensure the purchase of 1 and and the execution of construction work. During the same year, oscar Niemeyer was made director of the Department of Architecture and Urban Affairs, and Lucio Costa won the competition held for the plan of Brasilia. 
This chofce brought back together the members of a team that had already proven its worth. Between 1936 and 1943 , Costa and Niemeyer had worked on the construction of the Ministry of Education and Culture in Rio de Janeiro, Le Corbusier having previously been consulted for this profect. The definition of an urban ideal based on the separation of functions, the incorporation of vast natural spaces and a street plan whose wide traffic lanes broke with the tradition of narrower streets, was implicit in the theoretical training of Costa and Niemeyer. However, the practical development of their own style meant that the primary functionalism of the "International style" would be refected in favor of solutions better adapted to the Brazilian context. In this regard, it may be recalled that Niemeyer had built, in 1942-1944, at Kubitschek's request, the group at Pampuiha, after having designed, In collaboration with Costa, the Brazilian pavilition at the New York World's Fair in 1939.

The "pilot plan" that Costa drew up for Brasilia was one of great expression power. As he himself described it, it was born of "the inftial gesture of someone designating a place and taking possession of it: a cross formed by two bars intersecting at right angles". This figure was then adapted to the topography, and the natural slope of the ground; its orlentation was improved by curving the arms of one of the crossbars. The layout for Brasilia calls to mind not so much a cross but a giant bird in flight towards the southeast. The curving north-south axis traces the layout of the wide transportation artery. Along it are the residential zones separated into superquadras, all nearly selfcontained, each possessing its own commercial and leisure-time centres, green spaces, schools, churches and so forth. Six-storey buildings (quadras) on piles were built according to Le Corbusier's principles.

The perpendicular east-west axis, known as the Monumental Axis, links the administrative sections of the new city, which became the official capital in 1960. Oscar Niemeyer's most renowned edifices were built there. They are noteworthy in the purity of their forms and their obvious monumental character, the result of an intelligent balance between horizontal and vertical buildings, rectangular volumes and curved surfaces, and the raw, unfinished matertals and polished exteriors of certain structures. Among the most beautiful buildings in the urban landscape of Brasilia may be cited around the Plaza of Three Powers, the Planalto Palace, or the Hall of Government, the Congress, with its twin skyscrapers flanked by the cupola of the Senate building and by the Inverted one of the House of Representatives, and finally the Supreme Court. Other structures of an exceptional artistic quality are the esplanade of the Ministers, the Cathedral with its 16 concrete paraboloids 40 meters in helght, the Pantheon of Juscelino Kubitschek, and the National Theatre.

Because of the enormity of the challenge, the extravagant scale 
of the project, and the massive resources poured into it, the creation of Brasilia is unquestionably a major feat in the history of urban1sm. In 1960, at the end of President Kubitschek's term of office, and especially since 1964 , when a new policy was adopted and the or $1 \mathrm{~g}$ inal team of architects was disbanded, the new capital of Brazil encountered serious problems which, even today, have not been totally overcome.

Kubitschek, Costa and Niemeyer planned for 500,000 to 700,000 inhabitants; satellite cities were to absorb any greater population. Brasilia currently has a privileged population of 300,000 people, and a large, often transitory, population distributed among the seven satelitte cities, as well as in the poorer neighborhoods that were established to the detriment of the 1956-1957 profect. In the absence of both a master plan and a code of urbanism, the standards defined by Costa and Niemeyer have been infringed upon in the greatest disarray. Higher structures in certain sectors, construction in open spaces, modifications in the road network, and other transgressions have gravely altered a monumental landscape inttially of great quality.

Such degeneration and the threats that weigh on further development of Brasilia spurred Alotsio Magalhaes to create, in 1981, a working group for the preservation of the historical and cultural heritage of Brasilia. This group has assembled an 1mpressive amount of documentation and devoted much effort to finding prospective solutions. It has 1dentified for protection the three zones that are proposed in the nomination of Brasilia to the World Heritage List:

- a total protection zone covering Lucio Costa's pilot plan;

- a buffer zone in which a predominance of green spaces would be ensured;

- a peripheral zone including the artificial lake and its banks, virtually covered with residential bufldings. Protection in this area may be more flexible.

The working group also proposed the inscription of the older witnesses to the birth of Brasilia, that is, the cities and traditional habitations of the peripheral district (Planaltina, Brazlandia and eight former fazendas), as well as the workers' camps, which are evocative, but fragile, vestiges of the golden age of the construction of the capital (1957-1960).

ICOMOS, while expressing an opinion favorable in principle to the inclusion of Brasilia on the World Heritage List, considers that the property should be inscribed on condition that minimal guarantees of protection ensure the preservation of the urban creation of Costa and Niemeyer. 
The adoption of Costa's pllot plan was to enter into 1ts final phase in March 1987 and be submitted to relevant authortties during the course of the same year.

No specific date has been given insofar as the protective measures of buffer zones is concerned; the working group's wishes obviously do not constitute sufficient guarantee as to their implementation.

ICOMOS, October 1987 


\section{ICOMOS}

INTERNATIONAL COUNCIL ON MONUMENTS AND SITES CONSEIL INTERNATIONAL DES MONUMENTS ET DES SITES CONSEJO INTERNACIONAL DE MONUMENTOS Y SITIOS МЕЖЛУНАРОДНЫЙ СОВЕТ ПО ВОПРОСАМ ПАМЯТНИКОВ И ДОСТОПРИМЕЧАТЕЛЬНЫХ МЕСТ
LISTE DU PATRIMOINE MONDIAL
$N^{\bullet} 445$

\section{A) IDENTIF ICATION}

Blen proposé : Ensemble représentatif du Patrimolne historique, culturel, naturel et urbain de Brasilia

Lieu : District fédéral

Etat partie : Brésil

Date: 31 Décembre 1986

\section{B) RBCOMMANDATION DE L'ICOMOS}

Que le blen culturel proposé solt inscrit sur la liste du Patrimoline mondial à condition que les autorités brésiliennes adoptent une législation assurant la sauvegarde de la création urbaine de Costa et de Niemeyer.

\section{C) JUSTIFICATION}

Les principes de l'urbanisme du XXe siècle, tels qu'ils se sont exprimés en 1943 dans la Charte d'Athènes ou encore en 1946 dans la Manière de penser l'urbanisme de Le Corbuster, ont été rarement 1liustres a l'echelle d une captale, les seules exceptions notables sont constituées par Chandigârh, où Le Corbusier, nommé conselller architectural du gouvernement du Panjâb en 1950 , oeuvra pendant plusieurs annés en collaboration avec Pferre Jeanneret, Maxwell Fry et Jane Drew, et surtout par la capitale du Brés11, Brasilia, créée ex nihflo au centre d'un district fédéra1 de $5.814 \mathrm{~km} 2$ à partir de 1956 .

L'idée de fonder une capitale au coeur du Brésilest ancienne et s'étalt exprimée à plusieurs occasions depuis la fin du XVIIe siècle. En 1922, lors de la commémoration du centenalre de l'indépendance, le cholx de la réglon centre-ouest comme site de la future capitale fut symbolisé par l'érection de la "plerre Fondamentale", à quelques kflomètres au nord-est de l'actuelle Brasilia, près de Planaltina.

C'est Juscelino Kubitschek, élu Président de la République en 1955, qui fit de la création de la capitale un symbole de sa politique de mise en valeur de la totalité de l'espace brésilien, d'expansion industrielle et de grands travaux.

Dès 1956, le Président Kubitschek chargealt une commission de cholsir l'emplacement exact de la ville et un organisme exécutif, la Novacap, de mener a bien l'achat des terrafns et la

construction. La même année, Oscar Niemeyer étalt nommé Directeur 
du Département d'architecture et d'urbanisme et Lucio Costa remportalt le concours ouvert pour le cholx du plan de Brasilia.

Ces cholx reconstitualent une équipe qui avalt déjà falt ses preuves : de 1936 a 1943, Costa et N1emeyer avalent collaboré à la construction du Ministère de l'education et de la Culture à Rio-de-Janeiro, Le Corbusier ayant été consulté pour cette grande réalisation. La définition d'un ldéal urbain fondé sur la séparation des fonctions, sur le dégagement de vastes espaces naturels et le tracé de grandes voles de circulation bien distinctes de la rue traditionnelle était impliquée par la formation doctrinale de Costa et Niemeyer; mais leur évolution propre laissait prévolr le rejet du fonctionnalisme primaire du "style international" au profit de solutions mieux adaptées a 1 a situation brésilienne: à cet égard, on se souviendraque Niemeyer avait déjà édifié de 1942 a 1944 , à la demande de Kubitschek, 1 'ensemble de Pampulha, après avolr crée, en collaboration avec Costa, le pavilion brésilien de l'Exposition de New York en 1939.

Le "Plan pilote" de Costa pour Brasilia, d'une grande force expressive, est né, comme 11 l'a écrit lui-même, "du geste Initial de quiconque désigne un endrolt et en prend possession: deux barres qui se croisent à angle droit formant une crolx". Ce slgne a été ensulte adapté à la topographie, à la pente naturelle du terrain et à une mellleure orlentation : les bras de l'un des axes ont été recourbés. Le plan de Brasilia n'évoque pas une crolx, mals plutôt un olseau géant volant vers le sud-est. L'axe nord-sud, incurvé, définit le tracé de la large vole de communication autoroutière le long de laquelle s'alignent les zones réstientielles articulées en "super-quartiers" (superquadras) ayant chacun une semi-autonomie grâce à leurs aires commerciales et de lotsirs, espaces verts, écoles, églises, etc.. Les immeubles de six étages (quadras) sont construits sur pilotis selon les principes chers a Le Corbusier.

L'axe perpendiculaire est-ouest relie les quartiers administratifs et forme la grande vole monumentale de la nouvelle ville, devenue effectivement capitale en 1960. Oscar Niemeyer y a élevé ses plus célèbres édifices, remarquables par la pureté des formes et un évident caractère monumental, né d'oppositions savantes entre les battiments horizontaux et verticaux, les volumes rectangulaires et, les surfaces courbes, les matériaux bruts et l'épiderme satiné de certalnes constructions. Parmi les plus belles réalisations du paysage urbain de Brasilia, on citera autour de la Place des Trofs-Pouvoirs, le Palais du Planalto, ou Palais du Gouvernement, le Congres, avec ses deux gratte-ciel fumeaux flanqués de la coupole du Sénat et de celle, renversée, de la Chambre des Députés, le Palals de la Cour Suprême. D'autres créations d'une exceptionnelle qualité plastique sont l'esplanade des Ministères, la Cathédrale, avec ses selze parabolö̈des de béton hautes de $40 \mathrm{~m}$, le Panthéon de Juscelino Kubitschek, le 
Théâtre national, etc.

La création de Brasilia, par l'énormité de l'enjeu, la démesure du profet, l'ampleur des moyens mis en oeuvre, est

incontestablement un falt majeur dans l'histoire de l'urbanisme. Dès 1960, avec la fin de la présidence de Kubitschek, et surtout dès 1964, avec l'instauration d'une nouvelle politique et la dispersion de l'équipe des architectes, la jeune capitale du Brésil connut de graves difficultés, qui ne sont pas toutes surmontées aujourd'hui.

Kubitschek, Costa et Niemeyer prévoyalent de 500.000 à 700.000 habitants, des villes-satellites devant recevolr la population excédentaire. Brasilia abrite actuellement une population favortsée de 300.000 habitants, une grande masse de population souvent transitoire se répartissant dans sept villes-satellites, mals aussi dans des faubourgs misérables élevés au mépris du plan de 1956-1957. En 1'absence de tout plan régulateur et de tout code de l'urbanisme, les normes définies par Costa et Niemeyer ont été transgressées dans le plus grand désordre. Surélévations d'immeubles dans certains secteurs, constructions dans des espaces libres, modifications du réseau routier, etc. ont gravement altéré un paysage monumental d'une grande qualité intiale.

Cette dégradation et les menaces qui pèsent sur le développement de Brasilia ont incité Alofsio Magalhaes à créer, en 1981, un groupe de travail pour la préservation du patrimoine historique et culturel de Brasilia. Ce groupe, qui a rassemblé une importante documentation et s'est livré à une réflexion prospective poussée, a défint les trois zones de protection proposées pour l'inscription de Brasilia sur la Liste du Patrimolne mondial :

- une zone de protection absolue couvrant le Plan pilote de Lucio Costa,

- une zone tampon où la prédominance des espaces verts serait assurée,

- une zóne périphérlque incluant le lac artificiel et ses rives, presque entièrement bâties d'ensembles résidentiels. La protection ne peut être icl que plus souple.

Le groupe de travall a également proposé d'inscrire les témoins historiques de la naissance de Brastila, c'est-a-dire les villes et habitats traditionnels de la périphérie (Planaltina, Brazlandia et hult anciennes fazendas) ainsi que les campements ouvriers, vestiges émouvants maisfragiles de la grande époque de construction de la capitale (1957-1960).

L'icomos, tout en exprimant un avis de principe favorable à 1'inscription de Brasilia sur la Liste du Patrimoine mondial, estime que ce bien doft être inscrit à condition que des mesures 


\begin{abstract}
de protection minimales assurent la sauvegarde de la création urbalne de Costa et Niemeyer.

L'adoption du Plan pllote de Costa devalt entrer dans sa phase définftive en mars 1987 et être soumise aux Instances concernées au cours de cette même année.

Aucune précision de date n'est fournie en ce qui concerne les mesures de protection des zones-tampons, pour lesquelles les souhalts du groupe de travali ne constituent évidemment pas une garantie suffisante.
\end{abstract}

